Supplementary information for:

\title{
Does size matter? The influence of size, load factor, range autonomy and application type on the Life Cycle Assessment of current and future medium- and heavy-duty vehicles.
}

\author{
Romain Sacchi ${ }^{1 *}$, Christian Bauer ${ }^{1}$, Brian L. Cox ${ }^{2}$ \\ $1=$ Technology Assessment group, Laboratory for Energy Systems Analysis, Paul Scherrer Institut, Villigen, Switzerland \\ $2=$ INFRAS, Bern, Switzerland \\ *Corresponding author: email - romain.sacchi@psi.ch, telephone - +4176762 19 22, fax - +41 563102199
}

Word count, excluding reference: approx. 15,900

Single figures: 8

Multi-part figures: 7

Tables: 13

Total word count: $15,900+(8 * 300)+(7 * 600)=22,500$

\section{Vehicle input parameters}

Input parameters are used to obtain calculated parameters. Input parameters are defined across powertrains, size classes and years.

\subsection{Definitions}

Among the critically important parameters within each category, a few are worth detailing:

- In the "driving" category, parameters related to the lifetime of the vehicle are particularly important. While the lifetime of a vehicle does not vary over time, it does vary across size classes. Based on vehicle registration data in Switzerland ${ }^{1}$, the assumed lifetime ranges from 220,000 km for a 3.5-ton vehicle, to $1,050,000 \mathrm{~km}$ for 40-ton and 60-ton vehicles.

- The "powertrain" category contains important parameters such as the efficiency of the engine and transmission. These efficiencies vary across powertrain types and size classes, but also time. Values for current vehicles are obtained through calibration against parallel simulations conducted with the VECTO software ${ }^{2}$. Projection for efficiencies are based on carbon dioxide targets in the European Union for $\mathrm{HDV}^{3}$ - further explanation in Section 2.2.5 of manuscript.

- In the "glider" category, parameters such as the capacity utilization rate (or load factor), the aerodynamic drag coefficient or the power-to-mass ratio are important. The capacity utilization rate 
defines the ratio of the cargo load over the available payload. It is defined based on European statistics and seems to vary across size classes (i.e., on average from 0.64 for an 18 -ton vehicle, up to 0.83 for a 3.5-ton vehicle). Since it is calculated as the ratio between the product of the cargo mass times the distance driven and the product of the maximum cargo mass times the distance driven, it includes trips where the vehicles drive empty. The aerodynamic drag coefficient is used to calculate the resistance to overcome due to drag. It varies across size classes and time. Improvement of the aerodynamic drag is based on ${ }^{4}$. Other parameters of the same type include the rolling resistance, the road gradient, etc. Finally, the power-to-mass ratio helps to define the required engine power given the curb mass of the vehicle. Here, the car $2 \mathrm{db}$ database for trucks ${ }^{5}$, which contains technical specifications for thousands of trucks, is used. This ratio seems to be inversely correlated to the gross weight of the vehicles, with 22 $\mathrm{W}$ per $\mathrm{kg}$ of engine power for a 60 -ton vehicle against $66 \mathrm{~W}$ per $\mathrm{kg}$ for a 3.5 -ton vehicle. Some of the parameters extracted from Car2db-truck are presented in Figure 1.

- The "energy storage" category contains parameters particularly important for BEV trucks. For example, a parameter such as energy density of battery cell help size the batteries given a required range autonomy. It is expected to be close to $0.2 \mathrm{kWh} / \mathrm{kg}$ of battery cell nowadays, to gradually increase towards $0.5 \mathrm{kWh} / \mathrm{kg}$ of battery cell in 2050 . Such values are collected from ${ }^{6}$. Another parameter critical to energy storage is the battery lifetime kilometers. The lifetime of batteries that equip BEV trucks have an assumed lifetime of $400,000 \mathrm{~km}$ in 2020 , which increases to $700,000 \mathrm{~km}$ in 2050 . It implicitly supposes that the battery is replaced during the lifetime of vehicles that have a gross weight of 26-ton and above (as their lifetime is superior to the battery lifetime). For smaller size classes, while no battery replacement is assumed (since the vehicle lifetime is inferior to the battery lifetime), the entire environmental burden associated to the battery manufacture is allocated to the vehicle. For vehicles that require one or several replacements of the battery, the entire environmental burden of the last battery is allocated to the truck (the number of battery replacements is always rounded up).

- Finally, parameters in the "auxiliaries" category relate to the power drawn by non-engine services as well as heating and cooling. For example, the thermal heating demand varies across size class, but its means of generation varies across powertrain types: while heat is recovered from the heat of combustion for diesel vehicles, it has to be purposefully produced for BEV and FCEV vehicles. 


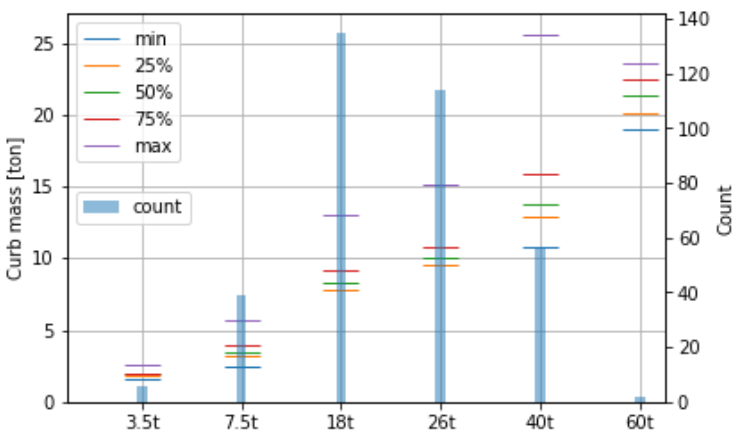

a) Curb mass function of gross vehicle weight

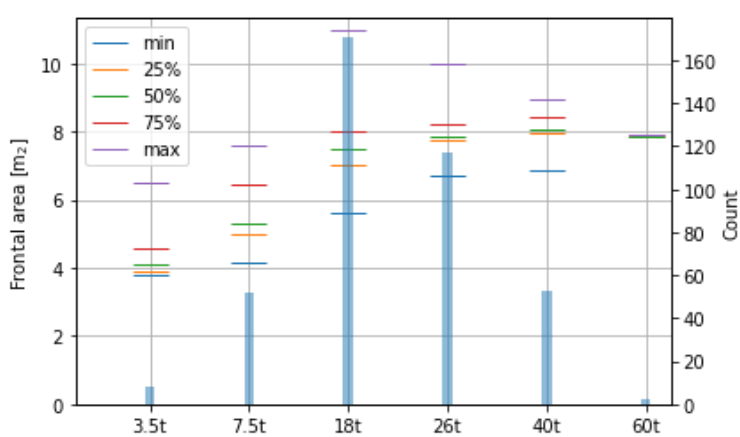

c) Frontal area function of gross vehicle weight

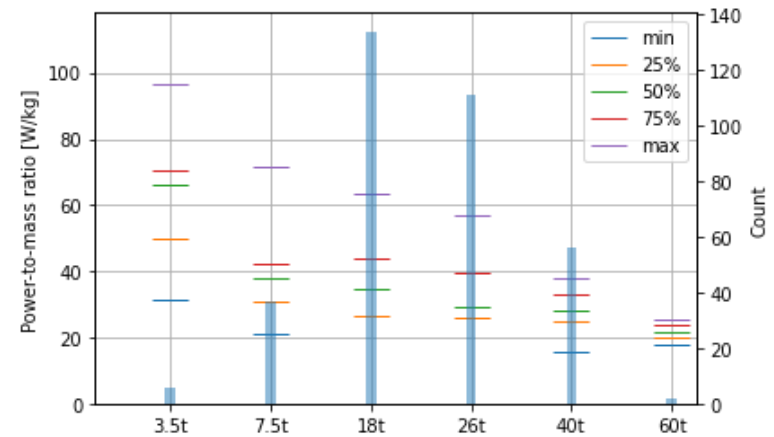

b) Power-to-mass ratio function of gross vehicle weight

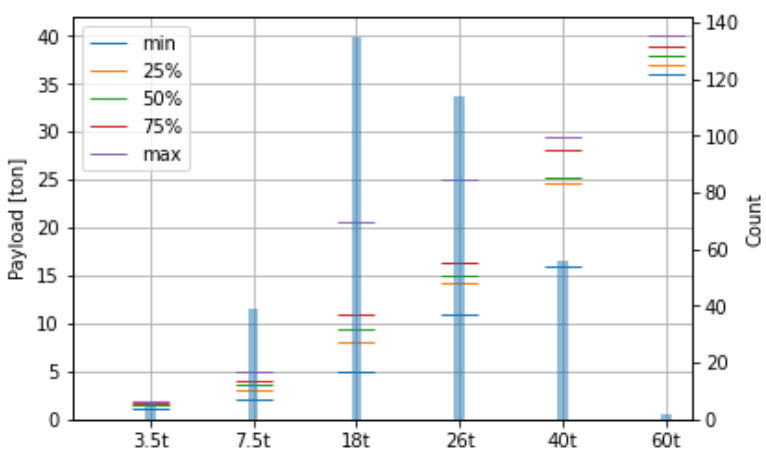

d) Maximum payload function of gross vehicle weight

Figure 1 Value distributions for some vehicle parameters extracted from Car2db-truck database

Table 1 Input parameters definition

\begin{tabular}{|c|c|c|c|c|c|c|c|}
\hline Category & $\begin{array}{l}\text { Differs across } \\
\text { powertrains? }\end{array}$ & $\begin{array}{l}\text { Differs across } \\
\text { sizes? }\end{array}$ & $\begin{array}{l}\text { Differs across } \\
\text { time? }\end{array}$ & Parameter name & Unit & $\begin{array}{l}\text { Importan } \\
\text { ce }\end{array}$ & Status \\
\hline \multirow[t]{2}{*}{ Driving } & No & Yes & No & lifetime kilometers & $\mathrm{km}$ & Critical & Good \\
\hline & No & Yes & No & kilometers per year & $\mathrm{km}$ & Limited & Good \\
\hline \multirow[t]{14}{*}{ Glider } & No & Yes & No & gross mass & $\mathrm{kg}$ & Critical & Good \\
\hline & No & Yes & No & glider base mass & $\mathrm{kg}$ & Critical & Acceptable \\
\hline & No & Yes & No & suspension mass & $\mathrm{kg}$ & Critical & Acceptable \\
\hline & No & Yes & No & braking system mass & $\mathrm{kg}$ & Critical & Acceptable \\
\hline & No & Yes & No & wheels and tires mass & $\mathrm{kg}$ & Critical & Acceptable \\
\hline & No & Yes & No & cabin mass & $\mathrm{kg}$ & Critical & Acceptable \\
\hline & Yes & Yes & No & exhaust system mass & $\mathrm{kg}$ & Critical & Acceptable \\
\hline & No & Yes & No & electrical system mass & $\mathrm{kg}$ & Critical & Acceptable \\
\hline & No & Yes & No & other components mass & $\mathrm{kg}$ & Critical & Acceptable \\
\hline & No & Yes & Yes & light weighting & unitless & Critical & Acceptable \\
\hline & Yes & Yes & No & power to mass ratio & $\mathrm{W} / \mathrm{kg}$ & Moderate & Good \\
\hline & No & Yes & No & frontal area & $\mathrm{m} 2$ & Critical & Good \\
\hline & No & No & Yes & aerodynamic drag coefficient & unitless & Critical & Acceptable \\
\hline & No & No & Yes & rolling resistance coefficient & unitless & Critical & Acceptable \\
\hline
\end{tabular}




\begin{tabular}{|c|c|c|c|c|c|c|c|}
\hline & No & No & No & average passengers & unit & Limited & Good \\
\hline & No & No & No & average passenger mass & $\mathrm{kg}$ & Limited & Good \\
\hline & No & Yes & No & load factor & unitless & Critical & $\begin{array}{l}\text { To be } \\
\text { improved }\end{array}$ \\
\hline \multirow[t]{20}{*}{ Powertrain } & No & Yes & Yes & drivetrain efficiency & unitless & Critical & Good \\
\hline & Yes & No & Yes & engine efficiency & unitless & Critical & $\begin{array}{l}\text { To be } \\
\text { improved }\end{array}$ \\
\hline & Yes & No & Yes & fuel cell stack efficiency & unitless & Critical & Acceptable \\
\hline & Yes & No & Yes & fuel cell power area density & $\mathrm{mW} / \mathrm{cm} 2$ & Unknown & Acceptable \\
\hline & Yes & No & No & $\begin{array}{l}\text { fuel cell ancillary BoP mass per } \\
\text { power }\end{array}$ & $\mathrm{kg} / \mathrm{kW}$ & Unknown & $\begin{array}{l}\text { To be } \\
\text { improved }\end{array}$ \\
\hline & Yes & No & No & $\begin{array}{l}\text { fuel cell essential BoP mass per } \\
\text { power }\end{array}$ & $\mathrm{kg} / \mathrm{kW}$ & Unknown & $\begin{array}{l}\text { To be } \\
\text { improved }\end{array}$ \\
\hline & Yes & No & Yes & fuel cell own consumption & $\mathrm{kW} / \mathrm{kW}$ & Limited & $\begin{array}{l}\text { To be } \\
\text { improved }\end{array}$ \\
\hline & Yes & No & No & converter mass & $\mathrm{kg}$ & Moderate & Acceptable \\
\hline & Yes & No & No & inverter fix mass & $\mathrm{kg}$ & Moderate & Acceptable \\
\hline & Yes & No & No & inverter mass per power & $\mathrm{kg} / \mathrm{kW}$ & Moderate & Acceptable \\
\hline & Yes & No & No & charger mass & $\mathrm{kg}$ & Moderate & Acceptable \\
\hline & Yes & No & No & power distribution unit mass & $\mathrm{kg}$ & Limited & Acceptable \\
\hline & Yes & No & Yes & emotor mass per power & $\mathrm{kg} / \mathrm{kW}$ & Moderate & Acceptable \\
\hline & Yes & No & No & emotor fixed mass & $\mathrm{kg}$ & Moderate & Acceptable \\
\hline & Yes & No & Yes & engine mass per power & $\mathrm{kg} / \mathrm{kW}$ & Moderate & Acceptable \\
\hline & Yes & No & No & engine fixed mass & $\mathrm{kg}$ & Moderate & Acceptable \\
\hline & No & No & No & $\begin{array}{l}\text { transmission mass per ton of gross } \\
\text { weight }\end{array}$ & $\mathrm{kg} / \mathrm{t}$ & Moderate & Acceptable \\
\hline & No & No & No & transmission fixed mass & $\mathrm{kg}$ & Moderate & Acceptable \\
\hline & Yes & No & Yes & combustion power share & unitless & Critical & Good \\
\hline & Yes & No & No & fuel cell power share & unitless & Critical & Good \\
\hline \multirow[t]{5}{*}{ Auxiliaries } & No & Yes & Yes & auxiliary power base demand & $\mathrm{W}$ & Limited & $\begin{array}{l}\text { To be } \\
\text { improved }\end{array}$ \\
\hline & No & Yes & Yes & heating thermal demand & $\mathrm{W}$ & Limited & $\begin{array}{l}\text { To be } \\
\text { improved }\end{array}$ \\
\hline & No & Yes & Yes & cooling thermal demand & $\mathrm{W}$ & Limited & $\begin{array}{l}\text { To be } \\
\text { improved }\end{array}$ \\
\hline & Yes & No & Yes & heating energy consumption & unitless & Limited & Acceptable \\
\hline & No & No & Yes & cooling energy consumption & unitless & Limited & Acceptable \\
\hline \multirow{13}{*}{$\begin{array}{l}\text { Energy } \\
\text { Storage }\end{array}$} & Yes & No & Yes & battery charge efficiency & unitless & Moderate & Acceptable \\
\hline & Yes & No & Yes & battery discharge efficiency & unitless & Moderate & Acceptable \\
\hline & Yes & No & No & battery DoD & unitless & Moderate & Acceptable \\
\hline & Yes & No & Yes & battery cell energy density & $\mathrm{kWh} / \mathrm{kg}$ & Critical & Acceptable \\
\hline & Yes & No & Yes & battery cell power density & $\mathrm{kW} / \mathrm{kg}$ & Critical & Acceptable \\
\hline & Yes & No & Yes & battery cell mass share & unitless & Critical & Acceptable \\
\hline & Yes & No & Yes & battery cell production energy & $\mathrm{kWh} / \mathrm{kg}$ & Critical & Acceptable \\
\hline & Yes & No & No & $\begin{array}{l}\text { battery cell production energy } \\
\text { electricity share }\end{array}$ & unitless & Critical & Acceptable \\
\hline & Yes & No & Yes & battery lifetime kilometers & $\mathrm{km}$ & Critical & $\begin{array}{l}\text { To be } \\
\text { improved }\end{array}$ \\
\hline & Yes & No & Yes & fuel cell lifetime kilometers & $\mathrm{km}$ & Critical & $\begin{array}{l}\text { To be } \\
\text { improved }\end{array}$ \\
\hline & Yes & No & No & fuel tank mass per energy & $\mathrm{kg} / \mathrm{kWh}$ & Unknown & $\begin{array}{l}\text { To be } \\
\text { improved }\end{array}$ \\
\hline & Yes & No & No & CNG tank mass slope & $\mathrm{kg} / \mathrm{kWh}$ & Unknown & $\begin{array}{l}\text { To be } \\
\text { improved }\end{array}$ \\
\hline & Yes & No & No & CNG tank mass intercept & $\mathrm{kg}$ & Moderate & Acceptable \\
\hline
\end{tabular}

\subsection{Values}

Default values for the vehicle input parameters are listed in the Excel file "input data.xlsx". 


\section{Sizing, energy consumption and emissions of vehicles}

\subsection{Mass distribution}

Table 2 shows the weight distribution of trucks of different size classes by components. Some components are common to all powertrains. The weight distributions for 3.5, 7.5, 18, 26, 32 and 60-ton trucks are based on an 18-ton and 40-ton vehicle. A light-weighting factor, referred to as "light weighting" in Table 1 and in the spreadsheet "input data.xlsx", is applied to the components of the chassis system.

Table 2 Components masses for diesel trucks in kilogram.

\begin{tabular}{|c|c|c|c|c|c|c|c|c|c|}
\hline & & $\begin{array}{l}\text { Rigid } \\
\text { truck, } \\
3.5 t\end{array}$ & $\begin{array}{l}\text { Rigid } \\
\text { truck, } \\
7.5 t\end{array}$ & $\begin{array}{l}\text { Rigid } \\
\text { truck, } \\
\text { 12t }\end{array}$ & $\begin{array}{l}\text { Rigid } \\
\text { truck, } \\
18 t\end{array}$ & Rigid truck, 26t & $\begin{array}{l}\text { Articulated } \\
\text { truck, 32t }\end{array}$ & $\begin{array}{l}\text { Articulated } \\
\text { truck, 40t }\end{array}$ & $\begin{array}{l}\text { Articulated truck, } \\
60 t\end{array}$ \\
\hline & Type & $\begin{array}{l}\text { rigid, } 2 \\
\text { axles, } \\
\text { box } \\
\text { body }\end{array}$ & $\begin{array}{c}\text { rigid, } 2 \\
\text { axles, box } \\
\text { body }\end{array}$ & $\begin{array}{l}\text { rigid, } 2 \\
\text { axles, box } \\
\text { body }\end{array}$ & $\begin{array}{l}\text { rigid, } 2 \\
\text { axles, box } \\
\text { body }\end{array}$ & $\begin{array}{l}\text { rigid, } 3 \text { axles, box } \\
\text { body }\end{array}$ & $\begin{array}{l}\text { semi-trailer, } \\
2+3 \text { axles, } \\
\text { curtain-sider }\end{array}$ & $\begin{array}{l}\text { semi-trailer, } \\
2+4 \text { axles, } \\
\text { curtain-sider }\end{array}$ & $\begin{array}{l}\text { semi-trailer }+ \text { trailer, } \\
2+4+2 \text { axles, curtain- } \\
\text { sider }\end{array}$ \\
\hline in kilograms & Gross weight & 3500 & 7500 & 12000 & 18000 & 26000 & 32000 & 40000 & 60000 \\
\hline \multirow[t]{5}{*}{ Powertrain } & $\begin{array}{l}\text { Engine } \\
\text { system }\end{array}$ & 151 & 324 & 518 & 777 & 1122 & 899 & 1124 & 1686 \\
\hline & $\begin{array}{l}\text { Coolant } \\
\text { system }\end{array}$ & 11 & 23 & 37 & 56 & 80 & 112 & 140 & 210 \\
\hline & Fuel system & 14 & 29 & 47 & 71 & 102 & 64 & 80 & 120 \\
\hline & $\begin{array}{l}\text { Exhaust } \\
\text { system }\end{array}$ & 44 & 94 & 150 & 225 & 325 & 176 & 220 & 330 \\
\hline & $\begin{array}{l}\text { Transmission } \\
\text { system }\end{array}$ & 83 & 177 & 283 & 425 & 613 & 446 & 558 & 837 \\
\hline Electrical system & & 24 & 52 & 83 & 125 & 180 & 212 & 265 & 398 \\
\hline \multirow[t]{4}{*}{ Chassis system } & Frame & 120 & 256 & 410 & 615 & 888 & 2751 & 3439 & 5159 \\
\hline & Suspension & 310 & 665 & 1064 & 1596 & 2305 & 2125 & 2656 & 3984 \\
\hline & $\begin{array}{l}\text { Braking } \\
\text { system }\end{array}$ & 24 & 52 & 83 & 125 & 180 & 627 & 784 & 1176 \\
\hline & $\begin{array}{l}\text { Wheels and } \\
\text { tires }\end{array}$ & 194 & 416 & 665 & 998 & 1100 & 1138 & 1422 & 2133 \\
\hline Cabin & Cabin & 175 & 375 & 600 & 900 & 1000 & 922 & 1153 & 1730 \\
\hline Other & & 659 & 1413 & 2260 & 230 & 2500 & 2160 & 2700 & 4050 \\
\hline $\begin{array}{l}\text { Curb mass, incl. } \\
\text { Trailer }\end{array}$ & & 1808 & 3875 & 6200 & 8210 & 10396 & 11633 & 14541 & 21812 \\
\hline Max, payload & & 1692 & 3625 & 5800 & 9790 & 15604 & 20367 & 25459 & 38189 \\
\hline Trailer/box & & 496 & 1063 & 1700 & 3210 & 4396 & 4583 & 7491 & 14762 \\
\hline $\begin{array}{l}\text { Trailer/box, \% } \\
\text { curb mass }\end{array}$ & & $27 \%$ & $27 \%$ & $27 \%$ & $39 \%$ & $42 \%$ & $39 \%$ & $52 \%$ & $68 \%$ \\
\hline $\begin{array}{r}\text { of which, } \\
\text { Frame }\end{array}$ & & 171 & 367 & 587 & 1108 & 1517 & 2068 & 2585 & 5094 \\
\hline $\begin{array}{r}\text { of which, } \\
\text { Suspension }\end{array}$ & & 70 & 150 & 240 & 453 & 620 & 845 & 1056 & 2081 \\
\hline $\begin{array}{r}\text { of which, } \\
\text { Wheels and tires }\end{array}$ & & 51 & 108 & 173 & 327 & 448 & 610 & 763 & 1504 \\
\hline $\begin{array}{r}\text { of which, } \\
\text { Brakes }\end{array}$ & & 27 & 57 & 92 & 173 & 237 & 323 & 404 & 796 \\
\hline $\begin{array}{r}\text { of which, } \\
\text { Others }\end{array}$ & & 179 & 383 & 613 & 1157 & 1584 & 2160 & 2700 & 5321 \\
\hline Tractor & & 1313 & 2813 & 4500 & 5000 & 6000 & 7050 & 7050 & 7050 \\
\hline Source & & 7 & & 5 & & 5,7 & & & $4,7,8$ \\
\hline
\end{tabular}




\subsection{Fuel pathways}

Table 3 Specifications of fuels used in trucks (and primary feedstock) in this study.

* using $\mathrm{CO}_{2}$ extracted from the atmosphere via direct air capture.

\# using $\mathrm{CO}_{2}$ captured from a coal power plant.

$\wedge$ using (time-weighted European average electricity over 2020-2032 period) @ 344 g CO 2 -eq./kWh.

$\alpha$ using average European electricity in 2015.

'without CCS.

\section{"with CCS.}

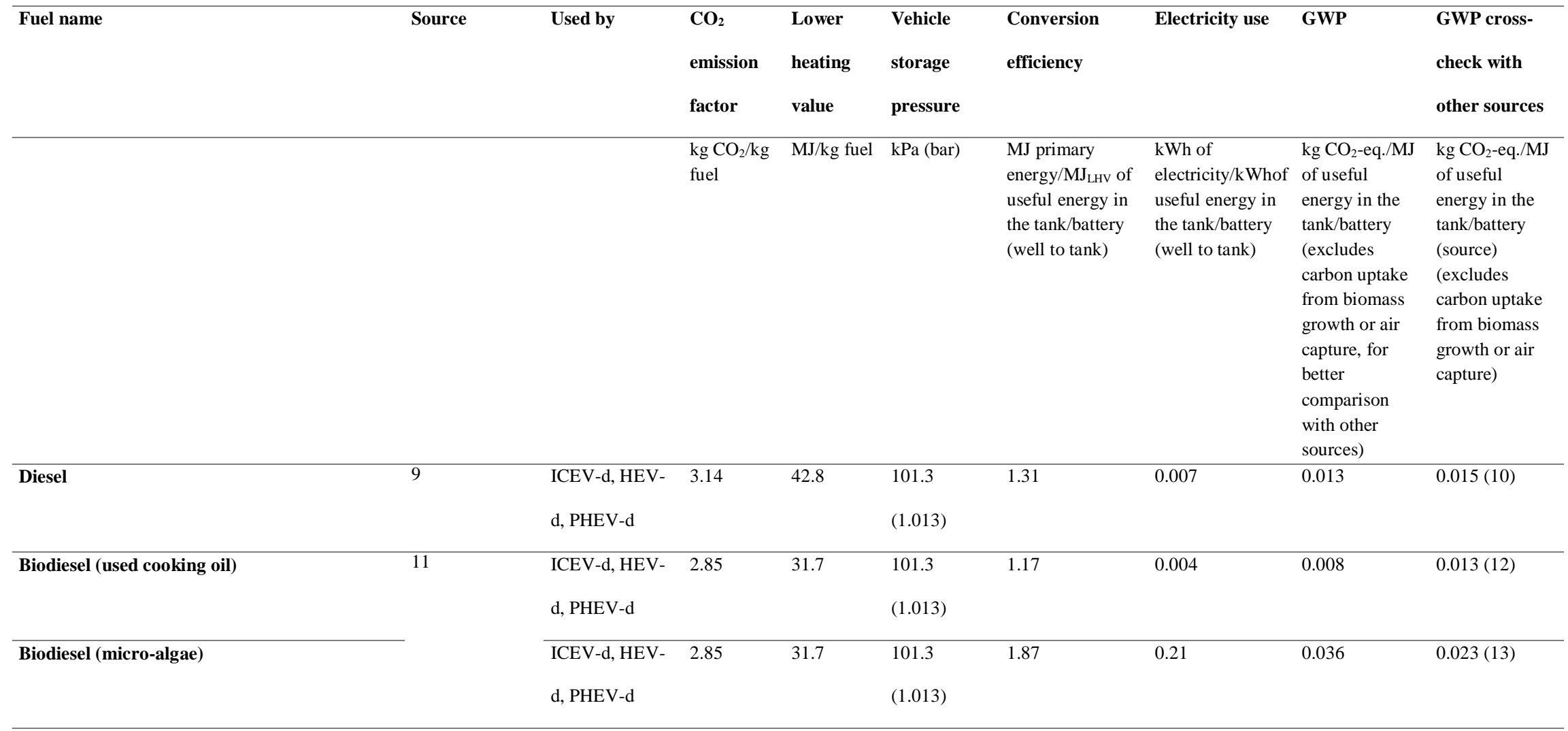




\begin{tabular}{|c|c|c|c|c|c|c|c|c|c|}
\hline Synthetic diesel (Fischer-Tropsch), with & 14 & ICEV-d, HEV- & 2.85 & 43.3 & 101.3 & 2.7 & 2.28 & $0.091^{* \wedge}$ & \\
\hline hydrogen from electrolysis & & d, PHEV-d & & & $(1.013)$ & & & & \\
\hline Natural gas & 9 & ICEV-g & 2.65 & 55.5 & $2,500(25)$ & 1.03 & 0.016 & 0.009 & $0.007(15)$ \\
\hline Bio-methane (sewage sludge) & 16 & ICEV-g & 2.65 & 55.5 & $2,500(25)$ & 1.13 & 0.031 & 0.002 & $0.003(18)$ \\
\hline Bio-methane (bio-waste) & & ICEV-g & 2.65 & 55.5 & $2,500(25)$ & 1.1 & 0.03 & 0.003 & $0.007(9)$ \\
\hline Hydrogen from electrolysis & 20,21 & FCEV & 0 & 120 & $35,000(350)$ & 5.07 & 1.87 & $0.183^{\wedge}$ & $0.245^{\alpha}(22)$ \\
\hline Hydrogen from steam methane reforming of & & FCEV & 0 & 120 & $35,000(350)$ & 1.73', & $0.006^{\prime}, 0.008^{\prime \prime}$ & $0.097^{\prime}, 0.045^{\prime \prime}$ & $0.101^{\prime}\left({ }^{22}\right)$ \\
\hline natural gas & & & & & & $1.78 ”$ & & & \\
\hline Hydrogen from steam methane reforming of & & FCEV & 0 & 120 & $35,000(350)$ & 1.92', & $0.097^{\prime}, 0.118^{\prime \prime}$ & 0.013', & $0.047^{\prime}\left({ }^{23}\right)$ \\
\hline \multirow[t]{2}{*}{ Hydrogen from gasification of woody biomass } & & FCEV & 0 & 120 & $35,000(350)$ & 2.49', & $0.143^{\prime}, 0.207^{\prime \prime}$ & 0.024', & $0.022^{\prime}\left({ }^{22}\right)$ \\
\hline & & & & & & 2.7” & & $-0.074 ”$ & \\
\hline Low voltage electricity & 9,24 & BEV & $\mathrm{n} / \mathrm{a}$ & $\mathrm{n} / \mathrm{a}$ & $\mathrm{n} / \mathrm{a}$ & 2.22 & 1.12 & $0.096^{\wedge}$ & \\
\hline
\end{tabular}




\subsubsection{Electricity}

Throughout this study where a geographical electricity mix is used, carculator_truck calculates the kilometerweighted mix for battery charging, hydrogen, and synthetic fuel production. This section explains such procedure with the case of Europe (in the political sense of its definition) for a 40-ton truck first used in 2020 with a lifetime of 12 years (total lifetime of 1,050,000 km with an annual mileage of 87,500 km).

The annual mixes in Table 4 are considered (in percentages). carculator_truck will consider the mixes from 2020 to 2032 (orange cells) as the truck from 2020 has a lifetime of 12 years. In parallel, it will also consider the environmental footprint of each electricity-producing technology per kilowatt-hour of electricity produced (the carbon footprint, in this case), as shown in Table 5. The annual mileage of the truck is assumed constant over time (although in practice, it is probable that a truck is more used in its first years than its last), which means that a same weight is attributed to each year. This gives the electricity mix and carbon footprint values given in Table 6.

Table 4 Projections for gross production electricity mixes in percentage for the European Union (EU-28). Source: 24

\begin{tabular}{rrrrrrrrrrr}
\hline year & Hydro & Nuclear & Gas & Solar & Wind & Biomass & Coal & Oil & Geothermal & Waste \\
\hline $\mathbf{2 0 2 0}$ & 12 & 26 & 17 & 4 & 12 & 6 & 22 & 1 & 0 & 0 \\
\hline $\mathbf{2 0 2 1}$ & 12 & 25 & 18 & 4 & 13 & 6 & 21 & 1 & 0 & 0 \\
\hline $\mathbf{2 0 2 2}$ & 12 & 24 & 18 & 5 & 13 & 6 & 21 & 1 & 0 & 0 \\
\hline $\mathbf{2 0 2 3}$ & 11 & 23 & 19 & 5 & 14 & 7 & 20 & 1 & 0 & 0 \\
\hline $\mathbf{2 0 2 4}$ & 11 & 22 & 19 & 6 & 14 & 7 & 20 & 1 & 0 & 0 \\
\hline $\mathbf{2 0 2 5}$ & 11 & 21 & 20 & 6 & 15 & 7 & 19 & 1 & 0 & 0 \\
\hline $\mathbf{2 0 2 6}$ & 11 & 21 & 20 & 6 & 15 & 7 & 18 & 1 & 0 & 0 \\
\hline $\mathbf{2 0 2 7}$ & 11 & 21 & 20 & 6 & 16 & 7 & 18 & 1 & 0 & 0 \\
\hline $\mathbf{2 0 2 8}$ & 11 & 21 & 19 & 7 & 16 & 8 & 17 & 1 & 0 & 0 \\
\hline $\mathbf{2 0 2 9}$ & 11 & 22 & 19 & 7 & 16 & 8 & 16 & 1 & 0 & 0 \\
\hline $\mathbf{2 0 3 0}$ & 11 & 22 & 19 & 7 & 17 & 8 & 16 & 1 & 0 & 0 \\
\hline $\mathbf{2 0 3 1}$ & 11 & 22 & 19 & 7 & 17 & 8 & 15 & 1 & 0 & 0 \\
\hline $\mathbf{2 0 3 2}$ & 11 & 21 & 20 & 7 & 17 & 8 & 14 & 1 & 0 & 0 \\
\hline $\mathbf{2 0 3 3}$ & 11 & 21 & 21 & 7 & 17 & 9 & 14 & 1 & 0 & 0 \\
\hline $\mathbf{2 0 3 4}$ & 11 & 21 & 21 & 7 & 17 & 9 & 13 & 1 & 0 & 0 \\
\hline $\mathbf{2 0 3 5}$ & 11 & 21 & 22 & 7 & 17 & 9 & 12 & 0 & 0 & 0 \\
\hline $\mathbf{2 0 3 6}$ & 11 & 21 & 22 & 8 & 17 & 9 & 12 & 0 & 0 & 0 \\
\hline $\mathbf{2 0 3 7}$ & 11 & 20 & 23 & 8 & 18 & 9 & 11 & 0 & 0 & 0 \\
\hline $\mathbf{2 0 3 8}$ & 11 & 20 & 24 & 8 & 18 & 10 & 10 & 0 & 0 & 0 \\
\hline $\mathbf{2 0 3 9}$ & 11 & 20 & 24 & 8 & 18 & 10 & 10 & 0 & 0 & 0 \\
\hline $\mathbf{2 0 4 0}$ & 11 & 20 & 25 & 8 & 18 & 10 & 9 & 0 & 0 & 0 \\
\hline
\end{tabular}


Table 5 Carbon footprint per kilowatt-hour produced [g CO2/kWh] for different technologies in the EU-28, with efficiencies adjusted by the REMIND baseline scenario but without transformation and distribution losses.

\begin{tabular}{rrrrrrrrrrr}
\hline year & Hydro & Nuclear & Gas & Solar & Wind & Biomass & Coal & Oil & Geothermal & Waste \\
\hline $\mathbf{2 0 2 0}$ & 4 & 6 & 663 & 76 & 15 & 28 & 904 & 928 & 55 & 0 \\
\hline $\mathbf{2 0 2 1}$ & 4 & 6 & 659 & 76 & 15 & 27 & 901 & 931 & 55 & 0 \\
\hline $\mathbf{2 0 2 2}$ & 4 & 6 & 656 & 75 & 15 & 27 & 898 & 935 & 54 & 0 \\
\hline $\mathbf{2 0 2 3}$ & 4 & 6 & 653 & 75 & 15 & 27 & 895 & 938 & 53 & 0 \\
\hline $\mathbf{2 0 2 4}$ & 4 & 5 & 649 & 74 & 15 & 27 & 893 & 942 & 53 & 0 \\
\hline $\mathbf{2 0 2 5}$ & 3 & 5 & 646 & 74 & 15 & 27 & 890 & 945 & 52 & 0 \\
\hline $\mathbf{2 0 2 6}$ & 3 & 5 & 642 & 73 & 15 & 27 & 887 & 948 & 52 & 0 \\
\hline $\mathbf{2 0 2 7}$ & 3 & 5 & 639 & 73 & 15 & 27 & 884 & 952 & 51 & 0 \\
\hline $\mathbf{2 0 2 8}$ & 3 & 5 & 635 & 72 & 15 & 27 & 881 & 955 & 51 & 0 \\
\hline $\mathbf{2 0 2 9}$ & 3 & 5 & 632 & 72 & 15 & 27 & 878 & 959 & 50 & 0 \\
\hline $\mathbf{2 0 3 0}$ & 3 & 5 & 628 & 72 & 15 & 27 & 875 & 962 & 50 & 0 \\
\hline $\mathbf{2 0 3 1}$ & 3 & 5 & 627 & 71 & 15 & 27 & 873 & 966 & 50 & 0 \\
\hline $\mathbf{2 0 3 2}$ & 3 & 5 & 625 & 71 & 15 & 27 & 871 & 969 & 49 & 0 \\
\hline $\mathbf{2 0 3 3}$ & 3 & 5 & 624 & 71 & 15 & 27 & 869 & 973 & 49 & 0 \\
\hline $\mathbf{2 0 3 4}$ & 3 & 5 & 622 & 71 & 15 & 27 & 867 & 977 & 49 & 0 \\
\hline $\mathbf{2 0 3 5}$ & 3 & 5 & 621 & 71 & 15 & 27 & 865 & 980 & 49 & 0 \\
\hline $\mathbf{2 0 3 6}$ & 3 & 5 & 619 & 71 & 14 & 27 & 863 & 984 & 49 & 0 \\
\hline $\mathbf{2 0 3 7}$ & 3 & 5 & 617 & 71 & 14 & 27 & 861 & 988 & 48 & 0 \\
\hline $\mathbf{2 0 3 8}$ & 3 & 5 & 616 & 70 & 14 & 27 & 859 & 992 & 48 & 0 \\
\hline $\mathbf{2 0 3 9}$ & 3 & 5 & 614 & 70 & 14 & 27 & 857 & 995 & 48 & 0 \\
\hline $\mathbf{2 0 4 0}$ & 3 & 5 & 613 & 70 & 14 & 27 & 854 & 999 & 48 & 0 \\
\hline & 3 & & & & & & & & \\
\hline
\end{tabular}

Table 6 Kilometer-weighted electricity mix and carbon footprint.

\begin{tabular}{|c|c|c|c|c|c|c|c|c|c|c|}
\hline year & Hydro & Nuclear & Gas & Solar & Wind & Biomass & Coal & Oil & Geothermal & Waste \\
\hline & \multicolumn{10}{|c|}{ Kilometer-weighted electricity mix } \\
\hline \multirow[t]{2}{*}{ 2020-2032 } & 11 & 22 & 19 & 6 & 15 & 7 & 19 & 1 & 0 & 0 \\
\hline & \multicolumn{10}{|c|}{$\begin{array}{l}\text { Kilometer-weighted carbon footprint for each technology } \\
\text { (with losses from production to low voltage supply) }\end{array}$} \\
\hline $2020-2032$ & 4 & 6 & 729 & 84 & 16 & 30 & 995 & 1021 & 61 & 0 \\
\hline & \multicolumn{10}{|c|}{ Kilometer-weighted carbon footprint per kilowatt hour (with losses to low voltage) } \\
\hline 2020-2032 & & & & & & 344 & & & & \\
\hline
\end{tabular}

\subsection{Tank-to-wheel energy consumption}

\subsubsection{Power requirement at wheels}

The calculation of the total resistance to overcome at the wheel level is the sum of the following resistances:

- The vehicle inertia, calculated as acceleration $\left[\frac{\mathrm{m}}{\mathrm{s}^{2}}\right] *$ driving mass $[\mathrm{kg}]$

- The rolling resistance, calculated as driving mass $[\mathrm{kg}] *$ rolling resistance coeff.* $9.81\left[\frac{\mathrm{m}}{\mathrm{s}^{2}}\right]$ 
- The air drag resistance, calculated as velocity ${ }^{2}\left[\frac{m^{2}}{s^{2}}\right] *($ frontal area $[\mathrm{m} 2] *$ drag coeff.* $\left.R H C_{\text {air }}\left[\frac{\mathrm{kg}}{\mathrm{m}^{3}}\right] / 2\right)$

- The road gradient resistance, calculated as driving mass $[\mathrm{kg}] * \sin ($ gradient $) * 9.81\left[\frac{\mathrm{m}}{\mathrm{s}^{2}}\right]$

- As well as resistance from braking, calculated as the force from the vehicle inertia when negative.

Figure 2 shows the contribution of each type of resistance as calculated by carculator_truck for the first hundred seconds of the "Urban delivery" driving cycle, for an $18 \mathrm{t}$ diesel truck.

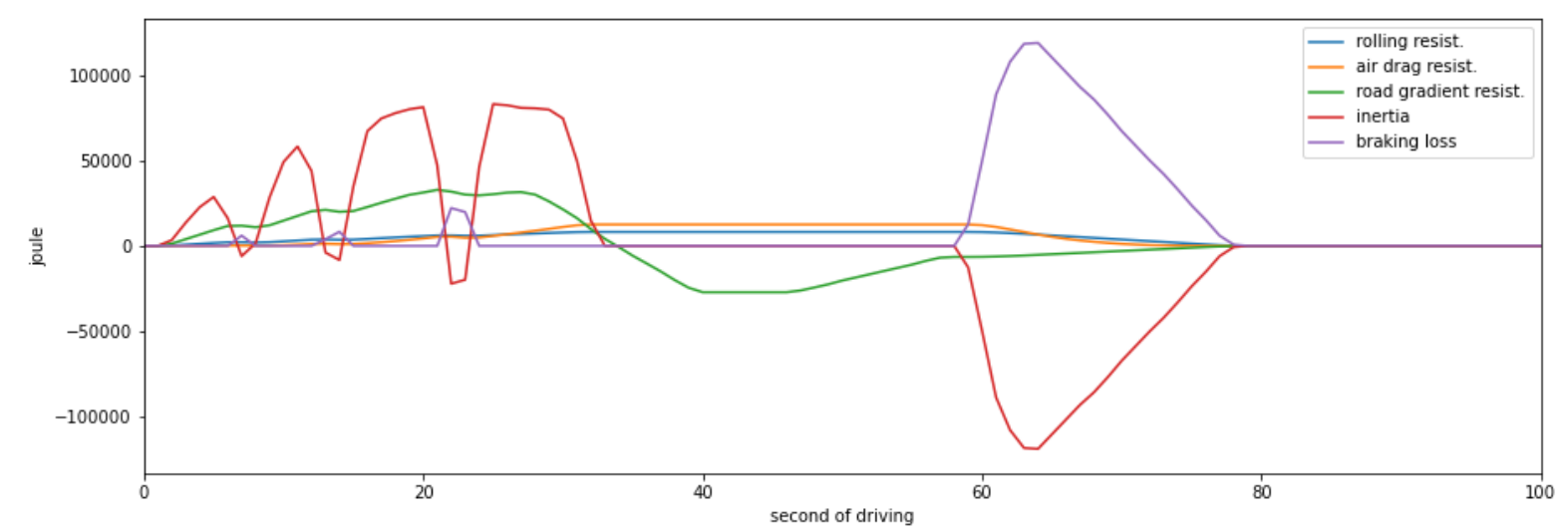

Figure 2 Resistance components at wheels.

For the three different driving cycles proposed by VECTO, the total resistance at the wheels calculated by carculator_truck is compared to what is obtained from VECTO simulations, for trucks with similar specifications, to ensure validity. Figure 3 shows such comparison for a 40t diesel truck with the "Urban delivery" driving cycle. Note that VECTO allows for negative power requirement after subtracting resistance from braking. 


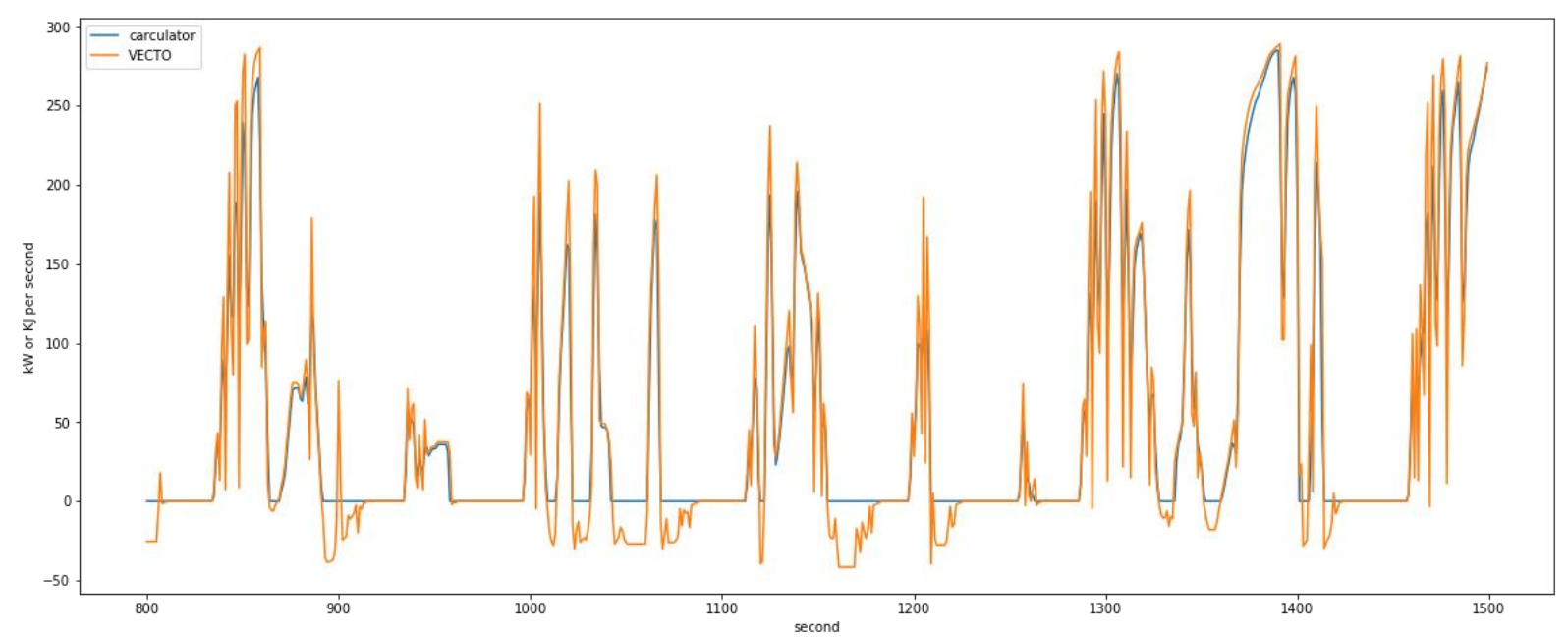

Figure 3 Comparison of total resistance at wheels, for a 40t diesel truck on the "Urban delivery" driving cycle

\subsubsection{Power requirement at tank}

Once the power requirement at the wheel level for each second is known (and validated), inefficiencies from the transmission line and the engine need to be accounted for. Here again, second-by-second data from VECTO simulations are used. VECTO uses a complex gearshift model combined with an engine-specific torque map that are too complex to be implemented in carculator_truck. Instead, the relation between transmission and engine efficiency on one end, and the relative power load (i.e., power load over the rated power output of the engine) on the other end, is used. Such relations are shown in Figure 4, for a 40t diesel truck, where the efficiency of the drivetrain (left) and engine (right) in relation to the power load is plotted for each second of the "Urban delivery" driving cycle, with a loading factor of $100 \%$. For example, Figure 4.a shows that the transmission efficiency (that is, from the wheels to the output shaft of the engine) is close to $85 \%$ at a power load of $20 \%$. In fact, most of the time when the truck is driving, the transmission operates at above $80 \%$ efficiency. Similarly, Figure 4.b shows that the peak engine efficiency is reached at about $40 \%$ power load, after which it remains more or less constant. A curve is fitted on the data points (red line). Using such fit removes some of the complexity considered in VECTO, depicted here by the measurements that deviate for the red curve. Nevertheless, it allows obtaining a reasonable estimate of the efficiency of these drivetrain components. 


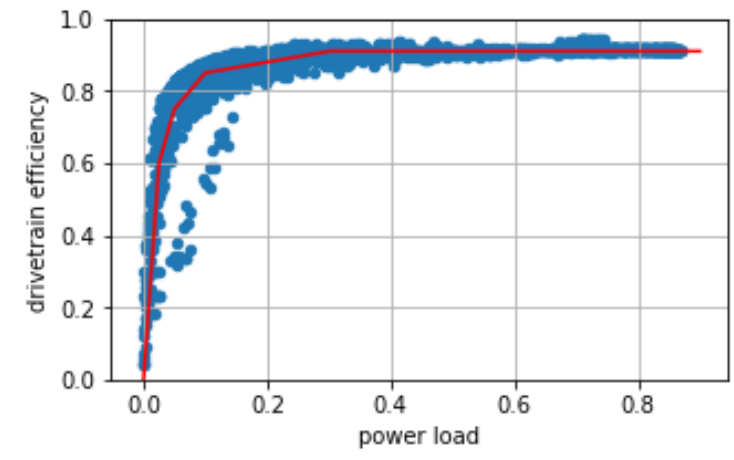

a) Drivetrain efficiency function of the power

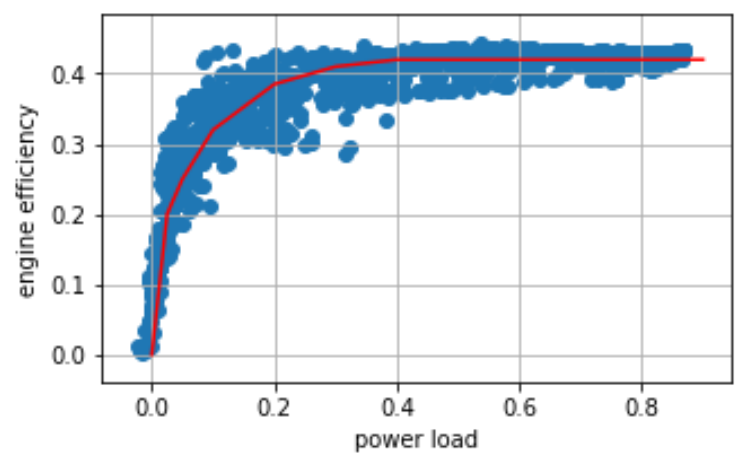

b) Engine efficiency function of the power load load

Figure 4 Drivetrain and engine efficiency in relation to power load, for a 40t diesel truck, fully loaded

This approach is validated by comparing the tank-to-wheel power requirement produced by VECTO and carculator_truck, as shown in Figure 5. While the fit is admittedly not perfect, it seems close enough for the purpose of this study. Over the entire $28 \mathrm{~km}$ of "Urban delivery" driving cycle, carculator_truck gives a tank-towheel energy consumption of only $0.8 \%$ superior to what VECTO calculates.

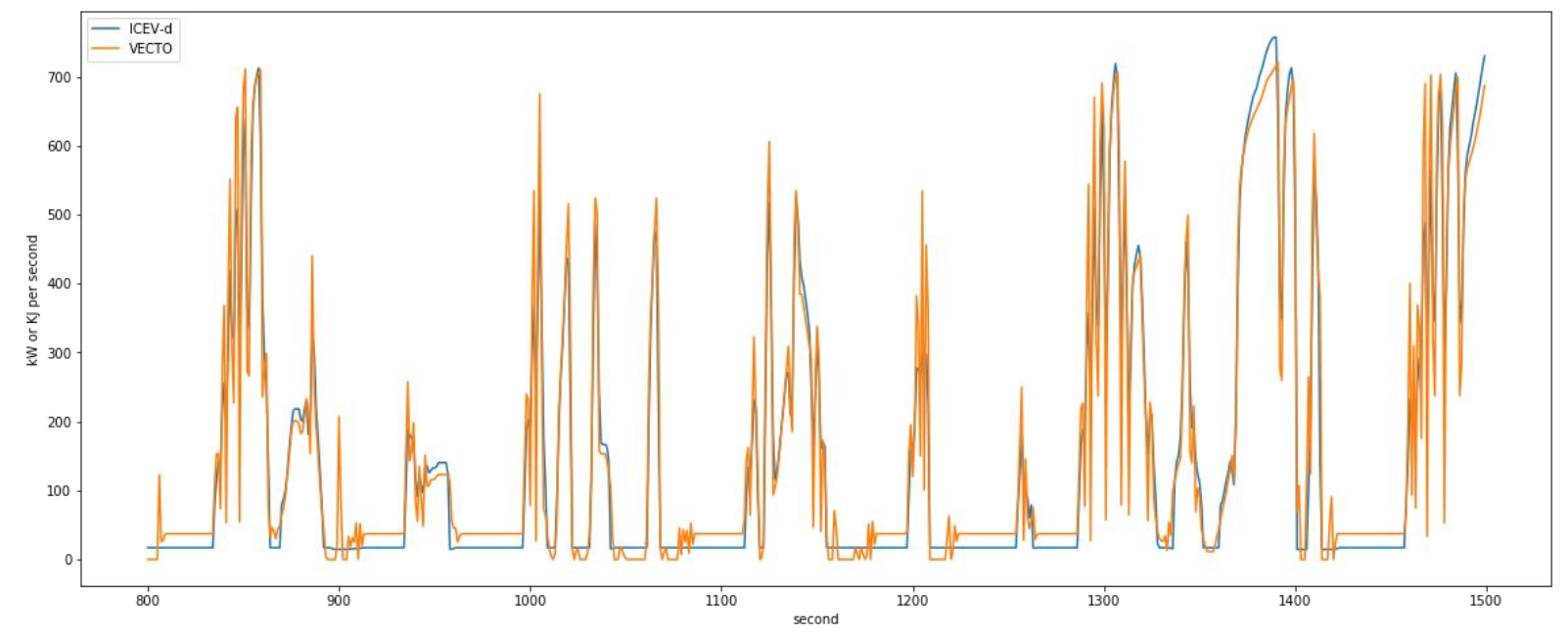

Figure 5 Comparison with VECTO for the tank-to-wheel power requirement for the "Urban delivery" driving cycle, from second 800 to second 1500

\subsubsection{Engine downsizing}

Such approach allows also reflecting the effect of engine downsizing. As the relative power load observed during the driving cycle is higher as the rated maximum power output of the engine is reduced, it operates at higher efficiency levels. Figure 6 compares the engine efficiency between a conventional 40t diesel truck and a dieselhybrid truck of similar size, but where the power of the combustion engine is reduced by $25 \%$ in favor of an 
electric motor. This figure confirms that the combustion engine of hybrid-diesel truck (HEV-d) reaches higher efficiency levels.

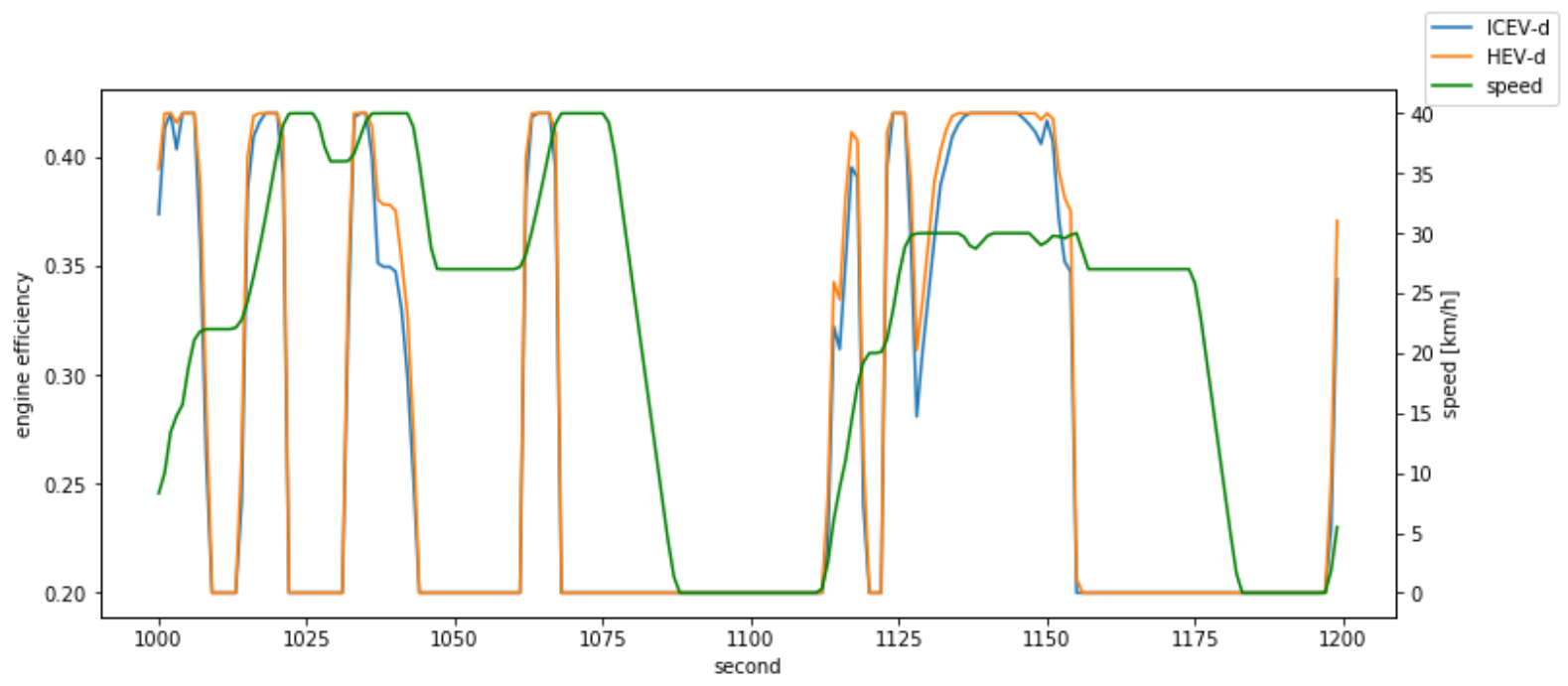

Figure 6 Engine efficiency comparison between a conventional (ICEV-d) and hybrid (HEV-d) 40t diesel truck

\subsection{Fuel-related exhaust emissions}

Figure 7 shows the current sulfur concentration in on-road diesel fuel in parts per million.
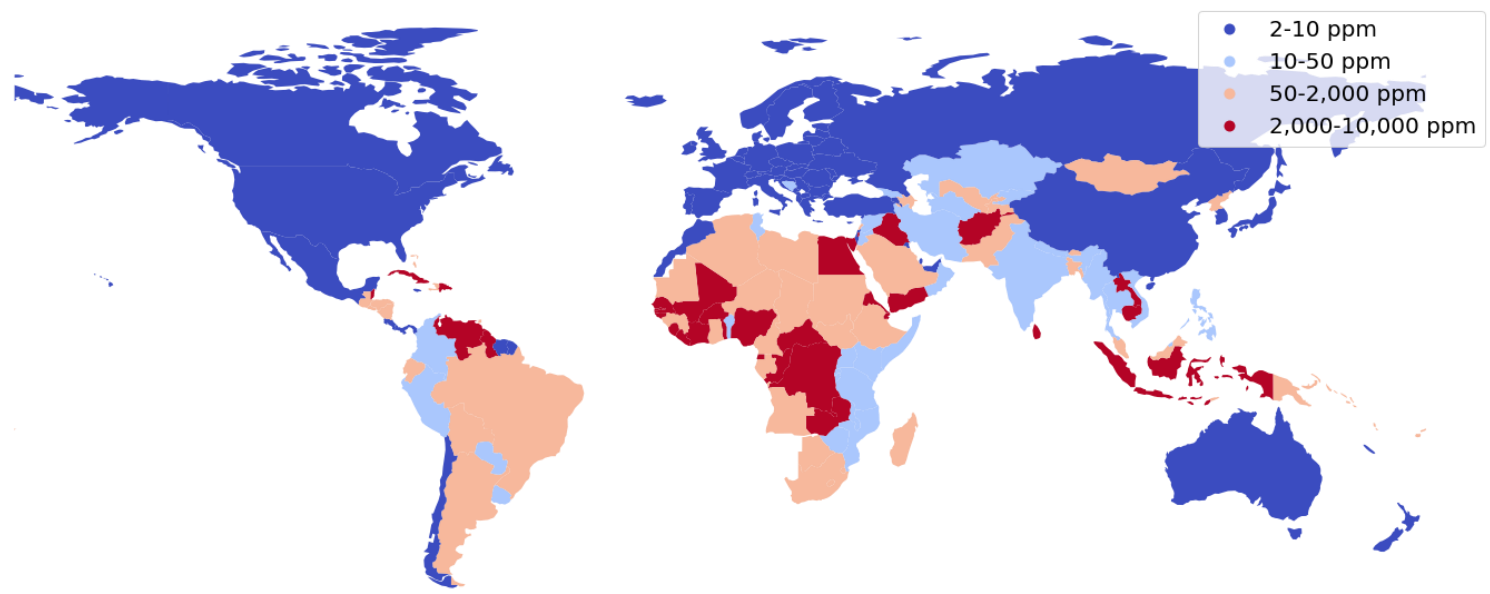

Figure 7 Sulfur content in diesel fuel in 2020, in parts per million. Source: $1,25,26$

\subsection{Emission of regulated substances}

Emission factors for trucks of different size classes, emission standards and powertrains are considered, function of the tank-to-wheel fuel consumption. A regression model is fitted and used to calculate emissions for every second of the driving cycle based on the fuel consumption. Such fits for diesel and natural gas trucks are shown in Figure 8. 

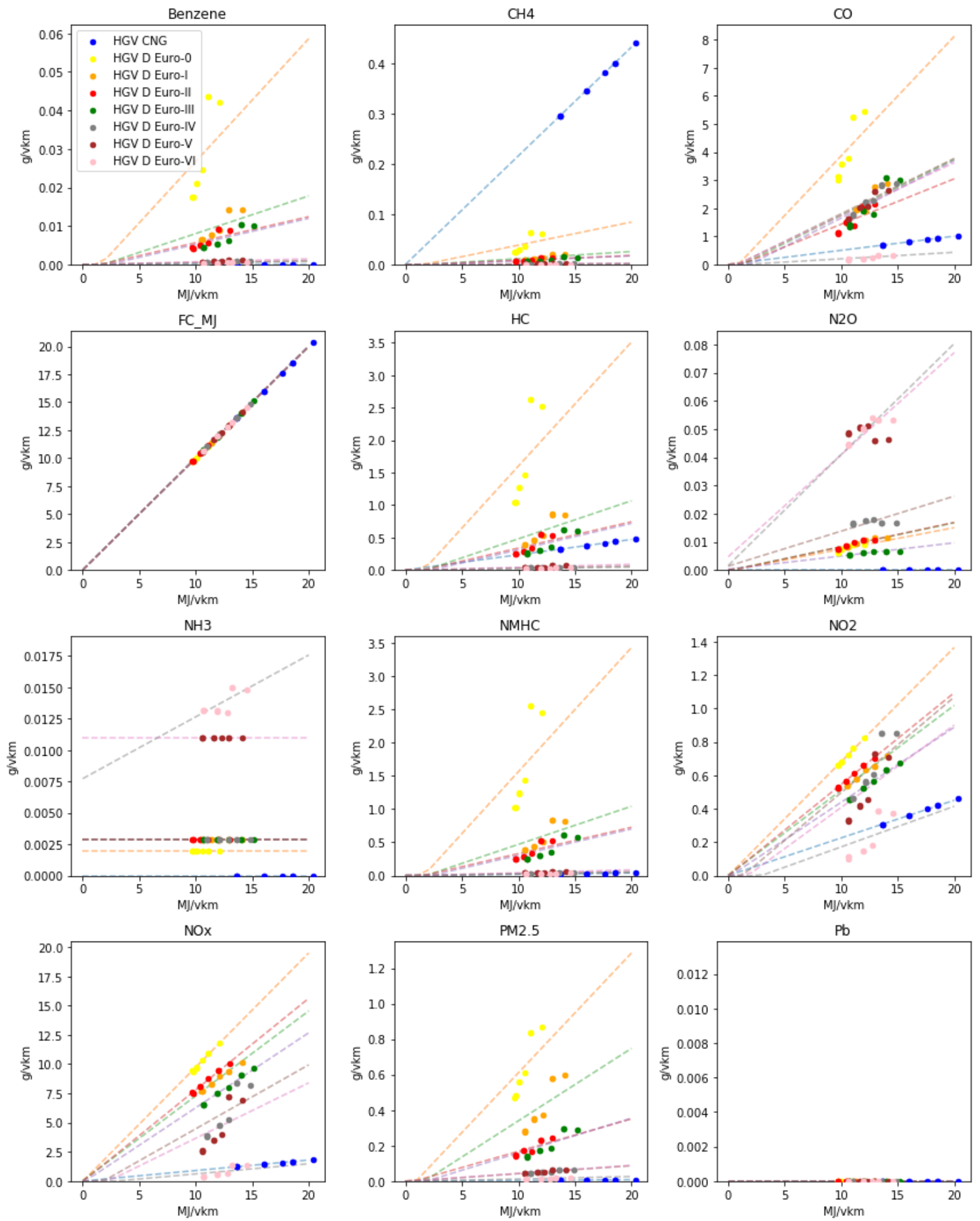

Figure 8 Regression fits based on emission factors from HBEFA $4.1^{1}$ for diesel and natural gas trucks

Emissions of regulated substances are distributed in different emission compartments, depending on the driving cycle. shows the three driving cycles available and their specifications. It also shows the share of the total distance driven in each emission compartment. 
Table 7 Driving cycles specifications.

\begin{tabular}{|l|l|l|l|}
\hline & Urban delivery & Regional delivery & Long haul \\
\hline Distance $[\mathrm{km}]$ & 28 & 26 & 108 \\
\hline Average speed $[\mathrm{km} / \mathrm{h}]^{*}$ & $9.9-10.7$ & $16.5-17.8$ & $19.4-21.8$ \\
\hline $\begin{array}{l}\text { Mean positive } \\
\text { acceleration }\left[\mathrm{m} . \mathrm{s}^{-2}\right]^{*}\end{array}$ & $0.26-0.55$ & $0.21-0.52$ & $0.13-0.54$ \\
\hline Idling time [s]* & $614-817$ & $110-220$ & $240-868$ \\
\hline $\begin{array}{l}\text { Share of distance in } \\
\text { urban environment }\end{array}$ & $100 \%$ & $15 \%$ & $0 \%$ \\
\hline $\begin{array}{l}\text { Share of distance in } \\
\text { suburban environment }\end{array}$ & $0 \%$ & $30 \%$ & $0 \%$ \\
\hline $\begin{array}{l}\text { Share of distance in rural } \\
\text { environment }\end{array}$ & $0 \%$ & $55 \%$ & $100 \%$ \\
\hline
\end{tabular}

* the interval of performances shown represents variability due to trucks size

\subsection{Foreground inventories}

Table 8 shows the various components datasets used. Their composition does not change across size classes, but across powertrains. All of these datasets and their content are available on the repository of the library

(https://github.com/romainsacchi/carculator_truck/tree/master/inventories).

Table 8 Truck component datasets

\begin{tabular}{|c|c|c|c|}
\hline Category & Name & Used by & Source \\
\hline \multirow[t]{7}{*}{ Powertrain } & gearbox, for lorry & all & 8 \\
\hline & exhaust system, for lorry & ICEV-d, HEV-d, PHEV-d, ICEV-g & \\
\hline & internal combustion engine, for lorry & ICEV-d, HEV-d, PHEV-d, ICEV-g & \\
\hline & retarder, for lorry & all & \\
\hline & transmission, for lorry & all & \\
\hline & $\begin{array}{l}\text { market for electric motor, electric passenger } \\
\text { car }\end{array}$ & PHEV-d, BEV, FCEV & 9 \\
\hline & fuel cell stack & FCEV & 27 \\
\hline \multirow[t]{4}{*}{ Energy storage } & $\begin{array}{l}\text { glass fibre reinforced plastic production, } \\
\text { polyamide, injection moulded }\end{array}$ & ICEV-g & 28 \\
\hline & fuel tank, compressed hydrogen gas, 700bar & FCEV & 29 \\
\hline & fuel tank, for diesel vehicle & ICEV-g & 8 \\
\hline & lithium-ion battery & PHEV-d, BEV, FCEV & $\begin{array}{l}30 \text { but with battery } \\
\text { cell production } \\
\text { energy requirements } \\
\text { adapted from } 28\end{array}$ \\
\hline \multirow{5}{*}{$\begin{array}{l}\text { Electrical } \\
\text { systems }\end{array}$} & power electronics, for lorry & all & 8 \\
\hline & market for inverter, for electric passenger car & BEV, PHEV-d & 9 \\
\hline & $\begin{array}{l}\text { market for power distribution unit, for electric } \\
\text { passenger car }\end{array}$ & BEV, PHEV-d & \\
\hline & market for charger, electric passenger car & BEV, PHEV-d & \\
\hline & $\begin{array}{l}\text { market for converter, for electric passenger } \\
\text { car }\end{array}$ & BEV, PHEV-d & \\
\hline \multirow[t]{3}{*}{ Chassis system } & frame, blanks and saddle, for lorry & all & 8 \\
\hline & suspension, for lorry & all & \\
\hline & tires and wheels, for lorry & all & \\
\hline Cabin & cabin, for lorry & all & \\
\hline
\end{tabular}




\begin{tabular}{|c|c|c|c|}
\hline Others & other components, for electric lorry & PHEV-d, BEV & \\
\hline & other components, for hybrid electric lorry & ICEV-d, HEV-d, PHEV-d, ICEV-g & \\
\hline \multirow[t]{7}{*}{ Use } & $\begin{array}{l}\text { fuel supply for diesel/gas/hydrogen/electric } \\
\text { vehicle }\end{array}$ & $\begin{array}{l}\text { ICEV-d, HEV-d, PHEV-d, ICEV-g, } \\
\text { FCEV }\end{array}$ & $\begin{array}{l}\text { See section } 2.2 \text { of } \\
\text { this document }\end{array}$ \\
\hline & electricity supply for electric vehicles & $\mathrm{BEV}, \mathrm{FCEV}$ & $24,31,32$ \\
\hline & hot pollutant emissions & ICEV-d, HEV-d, PHEV-d, ICEV-g & $\begin{array}{l}\text { See section } 2.5 \text { of } \\
\text { manuscript }\end{array}$ \\
\hline & noise emissions & all & $\begin{array}{l}\text { See section } 2.2 .7 .2 \\
\text { of manuscript }\end{array}$ \\
\hline & treatment of brake wear emissions, lorry & all & \multirow{3}{*}{$\begin{array}{l}\text { Modeling from }{ }^{33} \text {, } \\
\text { LCI datasets from } \\
9\end{array}$} \\
\hline & treatment of road wear emissions, lorry & all & \\
\hline & treatment of tire wear emissions, lorry & all & \\
\hline Maintenance & maintenance, lorry $16 / 28$ metric ton & all & 9 \\
\hline \multirow[t]{2}{*}{ Infrastructures } & market for road & all & \\
\hline & market for road maintenance & all & \\
\hline End-of-life & treatment of used lorry, $16 / 28$ metric ton & all & \\
\hline
\end{tabular}

\section{Validation}

This section briefly compares some calculated vehicle parameters (e.g., fuel consumption, engine power, payload, etc.) with vehicle specifications found in the literature and in manufacturers' documentation.

\subsection{Diesel trucks}

Literature fuel consumption values for ICEV-d trucks of different gross weight classes are superimposed to the range of values produced with carculator_truck using the "Urban delivery" and "Long haul" driving cycles, with a loading factor of $80 \%$ and $20 \%$ respectively - in order to produce "worst" and "best" scenarios. There does not seem to be any major disagreement, except for the ecoinvent truck vehicles of 7.5-16-ton weight class, which seem to have a fuel consumption superior to what carculator_truck calculates (see green stars in Figure 9). Unfortunately, the inventory report for truck vehicles used in ecoinvent ${ }^{34}$ does not specify under which circumstances fuel consumption values are obtained. It could however be because the ecoinvent datasets represent a range of truck sizes (in this case, from $7.5 \mathrm{t}$ to $16 \mathrm{t}$ trucks), rather than a specific truck. 
$7.5 \mathrm{t}$
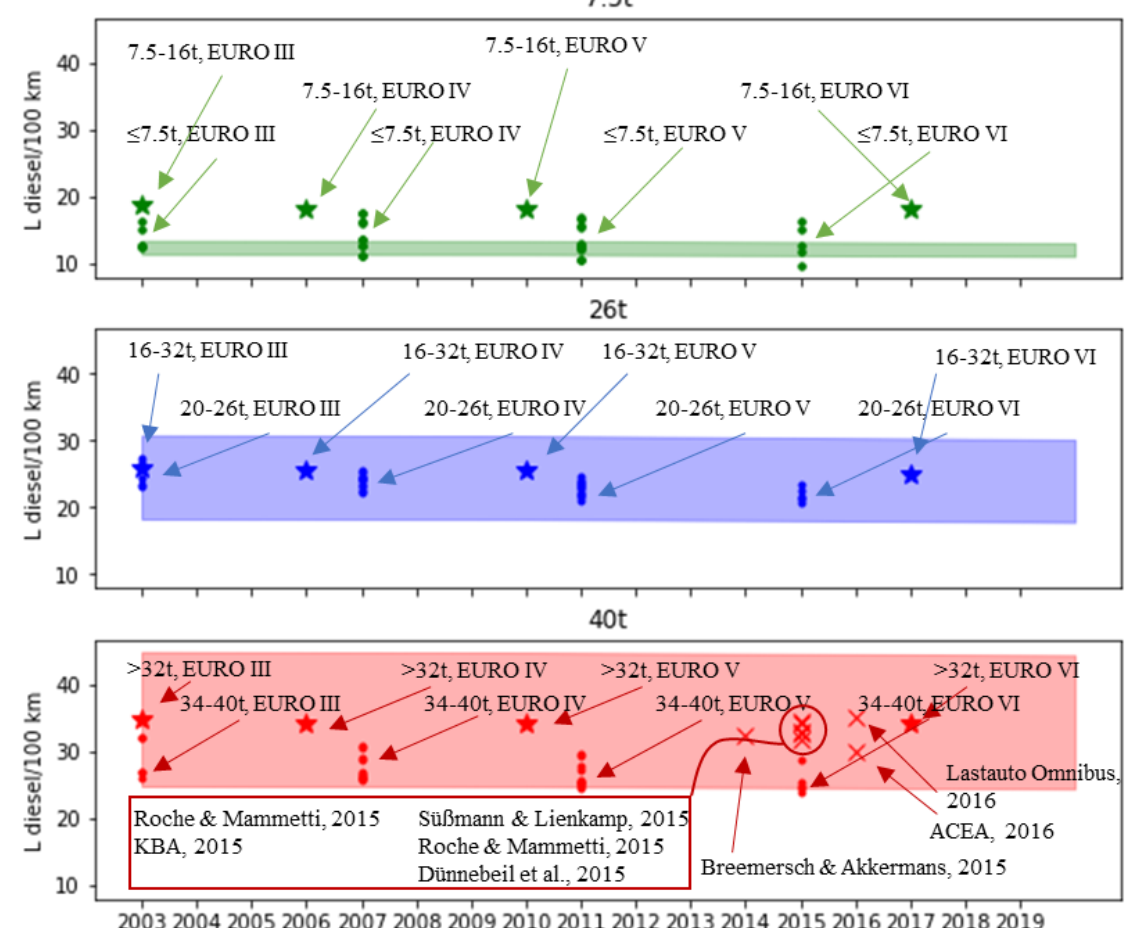

20032004200520062007200820092010201120122013201420152016201720182019
$18 \mathrm{t}$

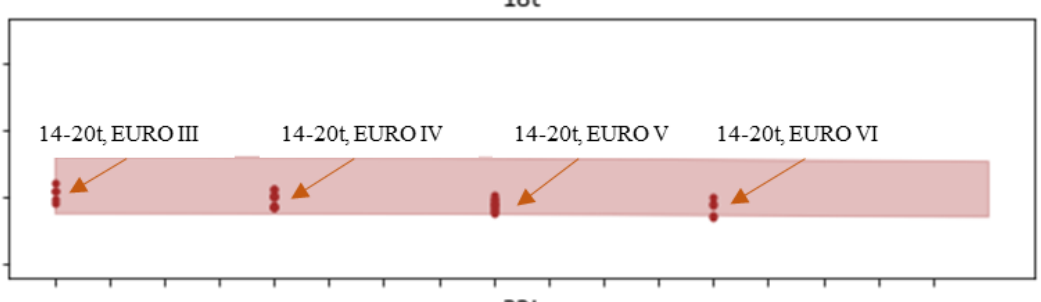

$32 \mathrm{t}$

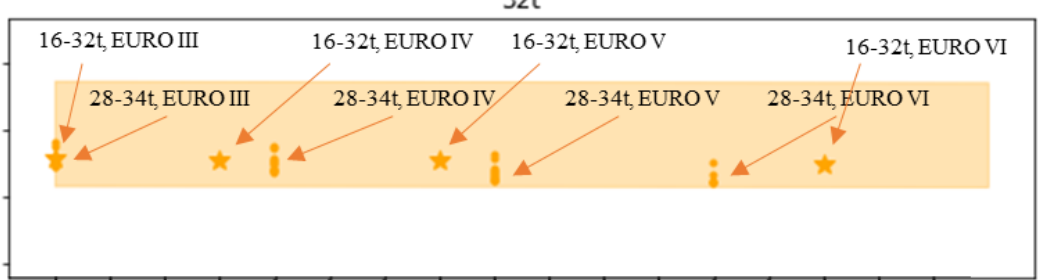

$200320042005200620072008200920102011201220132014201520162017200^{\prime} 182019$

the ecoinvent 3.7 vehicle

HBEFA 4.1 vehicle (urban $30 \mathrm{~km} / \mathrm{h}$, urban $50 \mathrm{~km} / \mathrm{h}$, rural $70 \mathrm{~km} / \mathrm{h}$, motorway $80 \mathrm{~km} / \mathrm{h}$, motorway $100 \mathrm{~km} / \mathrm{h}$ )

Other source

Figure 9 Fuel consumption for diesel trucks in L diesel per $100 \mathrm{~km}$, against literature data. Shaded areas: the upper bound is calculated with the "Urban delivery" driving cycle with a loading factor of $80 \%$, the lower bound is calculated with the "Long haul" driving cycle with a loading factor of $20 \%$ 


\subsection{Battery electric trucks}

A few specifications from manufacturers wishing to enter the market of battery electric trucks are collected from the Internet. Most models are either at the stage of prototyping, road testing or have only recently started commercialization. Because of this, values in Table 9 are based on manufacturers claimed performances. Most of the models found are designed for urban delivery applications, with an autonomy range inferior to $300 \mathrm{~km}$, to favor payload capacity.

Table 9 Battery electric trucks specifications.

\begin{tabular}{|c|c|c|c|c|c|c|c|c|}
\hline Brand & Model & GVW [ton] & $\begin{array}{l}\text { Max. Payload } \\
\text { [ton] }\end{array}$ & $\begin{array}{l}\text { Engine power } \\
{[\mathrm{kW}]}\end{array}$ & $\begin{array}{l}\text { Battery capacity } \\
{[\mathrm{kWh}]}\end{array}$ & $\begin{array}{l}\text { Range } \\
{[\mathrm{km}]}\end{array}$ & $\begin{array}{l}\text { Electricity } \\
\text { consumption } \\
{[\mathrm{kWh} / \mathrm{km}]} \\
\end{array}$ & Source \\
\hline Freightliner & eCascadia & 36.2 & & 391 & 475 & 400 & 1.19 & 35 \\
\hline Freightliner & eM2 & 11.8 & & 224 & 315 & 370 & 0.85 & 36 \\
\hline Volvo & VNR electric & 29.9 & 19.2 & 400 & 300 & $120-281$ & $1.06-2.50$ & 37 \\
\hline Workhorse & $\begin{array}{l}\text { C- } 650 \& \text { C- } \\
1000\end{array}$ & 5.7 & & & 70 & 160 & 0.44 & 38 \\
\hline Tesla & Semi & 36.2 & 22 & 745 & 500 & 480 & 1.04 & 6,39 \\
\hline Tesla & Semi & 36.2 & 12 & 745 & 1100 & 800 & 1.38 & \\
\hline BYD & T3 & 2.8 & 0.8 & & 43 & 250 & 0.17 & 40 \\
\hline BYD & T5 & 7.3 & 2.6 & & 150 & 250 & 0.60 & \\
\hline BYD & $\mathrm{T} 7$ & 10.8 & 5 & & 175 & 200 & 0.88 & \\
\hline$\overline{\text { BYD }}$ & J9D & 36.2 & & & 175 & 100 & 1.75 & \\
\hline BYD & T9 & 36.2 & & & 350 & 200 & 1.75 & \\
\hline Mercedes & eActros & 25 & 5 & 250 & 240 & 200 & 1.20 & 41 \\
\hline
\end{tabular}

Subplots in Figure 10 superimpose the manufacturers specifications shown in Table 9 to the spectrum of possible values produced by carculator_truck with all but one parameter set to default values, using the "Urban delivery" and "Long haul" driving cycles and their respective range autonomy (i.e., 150 and $800 \mathrm{~km}$ ). The only parameter that is not set to its default value is the capacity utilization rate, which has been set to 0 (i.e., empty trailer), to align with the manufacturers specifications. Regarding the comparison on maximum and battery capacity, the choice of manufacturers of minimizing battery size to the profit of payload appears clear, as most of them are positioned in the upper range and lower range of Figure 10.a and Figure 10.c respectively.

Overall, the subplots of Figure 10 do not seem to show any major disagreement between the values produced by carculator_truck and the few models that exist nowadays. It is important to note though some variability in terms of electricity consumption per km among advertised values by manufacturers for trucks of capacity of $30 \mathrm{t}$ and above. 


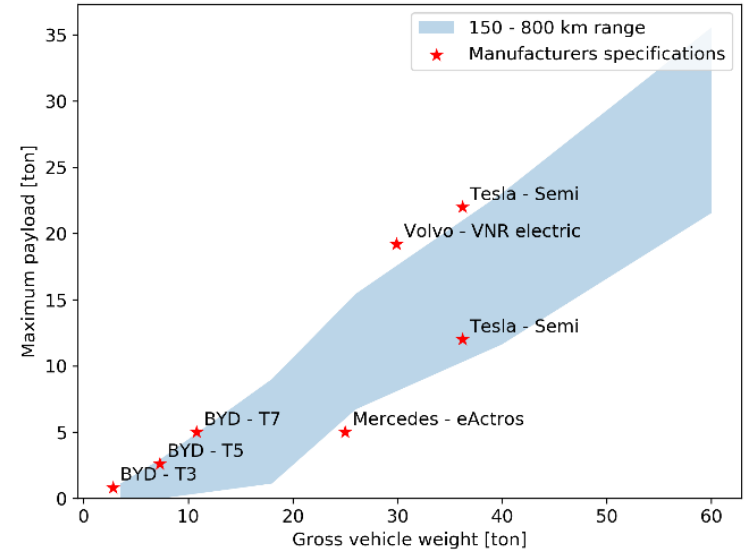

a) Maximum payload and gross vehicle weight

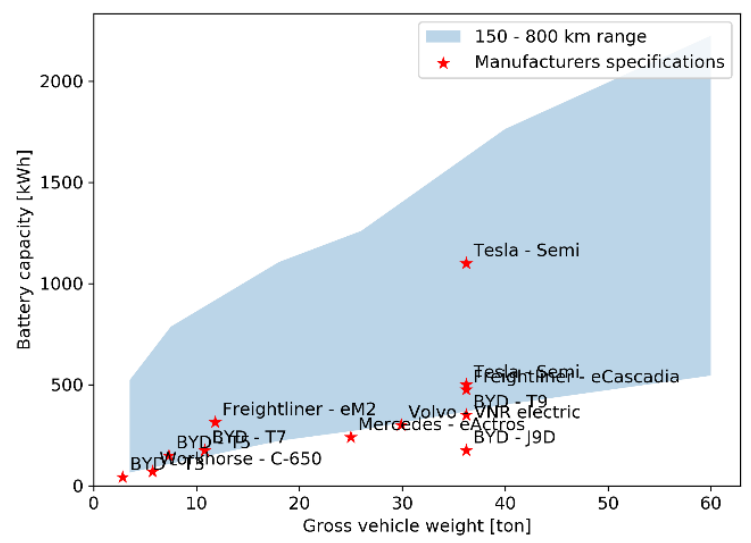

c) Battery capacity and gross vehicle weight

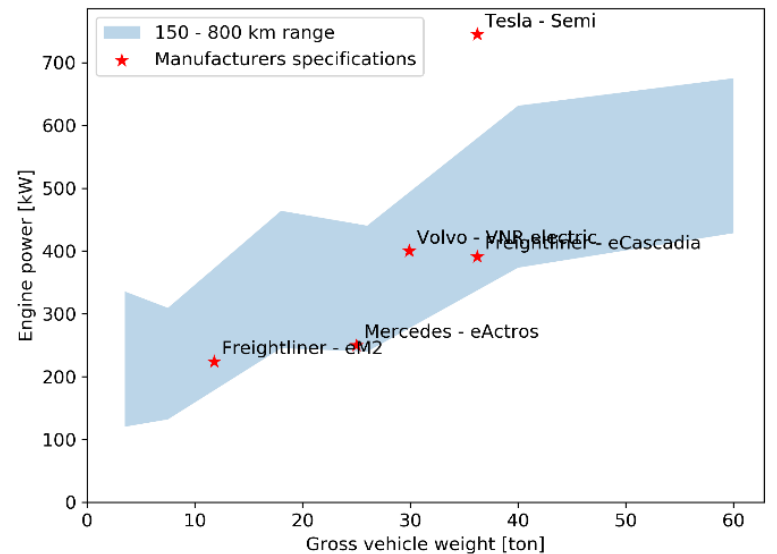

b) Engine power and gross vehicle weight

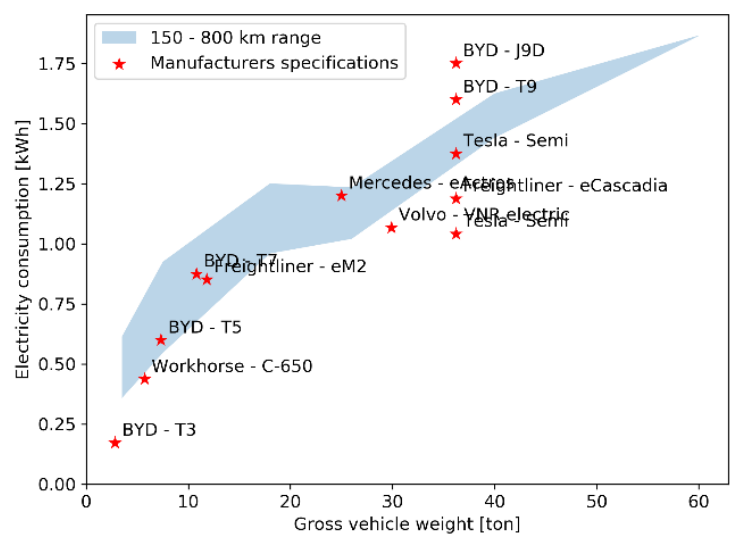

d) Electricity consumption and gross vehicle weight

Figure 10 Validation against existing battery electric truck models

\subsection{Fuel cell electric trucks}

A few completed projects of fuel cell electric trucks exist in Europe and the United States. While it is certainly too early to obtain performance values over a substantial number of kilometers, some specifications are given for some of them, as listed in Table 10. Comparatively to the battery electric models described in the previous section, FCEV trucks are designed with a greater range autonomy, mainly comprised between 200 and $400 \mathrm{~km}$. Information on the payload capacity could unfortunately not be found. Figure 11 compares the spectrum of values produced by carculator_truck with the "Urban delivery" and "Long haul" driving cycles and the vehicle specifications listed in Table 10. No major disagreement is observed among the described vehicle parameters, except for the engine and the fuel cell stack power output. Indeed, for the 3.5-7.5-ton gross vehicle weight 
interval, the model seems to overestimate the engine and fuel cell stack power output required, compared to the Renault Maxicity $\mathrm{H} 2$ specifications. Also, it is to note that changes in the driving cycle does not affect the required engine or the fuel cell stack power, which explains the narrow ranges in Figure 11.a and b.

Table 10 Fuel cell electric trucks specifications.

\begin{tabular}{|c|c|c|c|c|c|c|c|c|c|}
\hline Brand & Model & $\begin{array}{l}\text { GVW } \\
\text { [ton] }\end{array}$ & $\begin{array}{l}\text { Engine } \\
\text { power }[k W]\end{array}$ & $\begin{array}{l}\text { Hydrogen tank } \\
\text { capacity [kg H2] }\end{array}$ & $\begin{array}{l}\text { Fuel cell stack } \\
\text { output }[k W]\end{array}$ & $\begin{array}{l}\text { Battery } \\
\text { capacity } \\
{[\mathrm{kWh}]}\end{array}$ & $\begin{array}{l}\text { Range } \\
{[\mathbf{k m}]}\end{array}$ & $\begin{array}{l}\text { TtW energy } \\
{[\mathrm{kWh} / \mathrm{km}]}\end{array}$ & Source \\
\hline MAN & TGS 18.320 & 34 & 250 & 31 & 100 & 120 & 375 & 2.76 & 42 \\
\hline Hyundai & Xcient & 36 & 350 & 34.5 & 190 & 73 & 400 & 2.88 & 43 \\
\hline Renault & Maxity H2 & 4.5 & 47 & 4 & 20 & 42 & 200 & 0.67 & 44 \\
\hline VDL & H2-Share & 27 & 210 & 30 & 88 & 84 & 400 & 2.50 & 45 \\
\hline Scania & $\mathrm{H} 2$ truck & 27 & 290 & 33 & 90 & 56 & 400 & 2.75 & 46 \\
\hline Kenworth & T680 & 36 & 360 & 30 & 85 & 100 & 320 & 3.13 & 47 \\
\hline UPS & $\mathrm{H} 2$ truck & 12 & & 10 & 31 & 45 & 200 & 1.67 & 48 \\
\hline
\end{tabular}

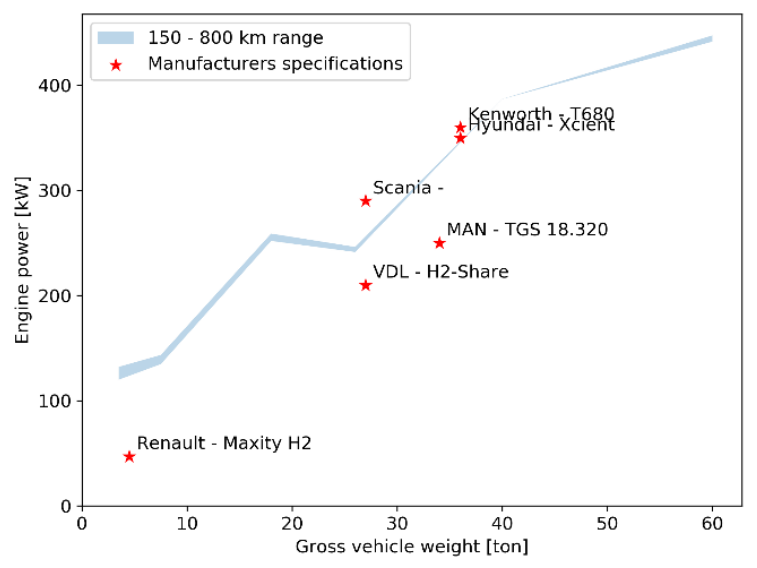

a) Engine power output and gross vehicle weight

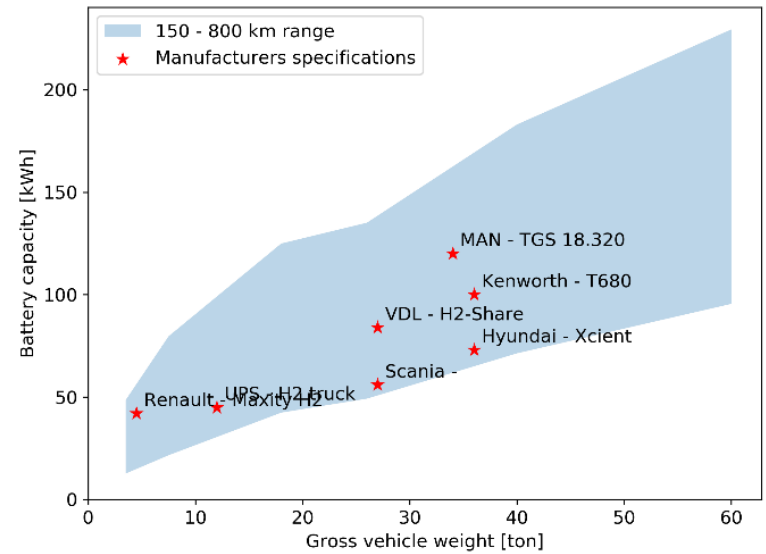

c) Battery capacity and gross vehicle weight

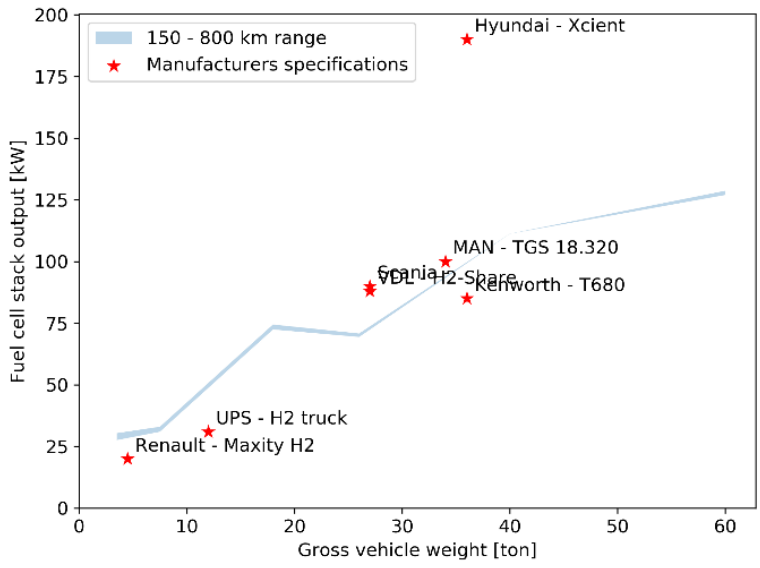

b) Fuel cell stack power output and gross vehicle weight

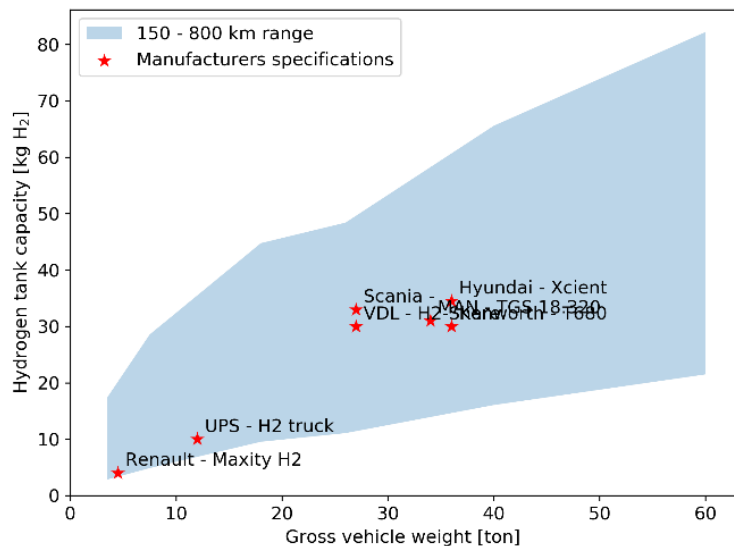

d) Hydrogen tank capacity and gross vehicle weight 


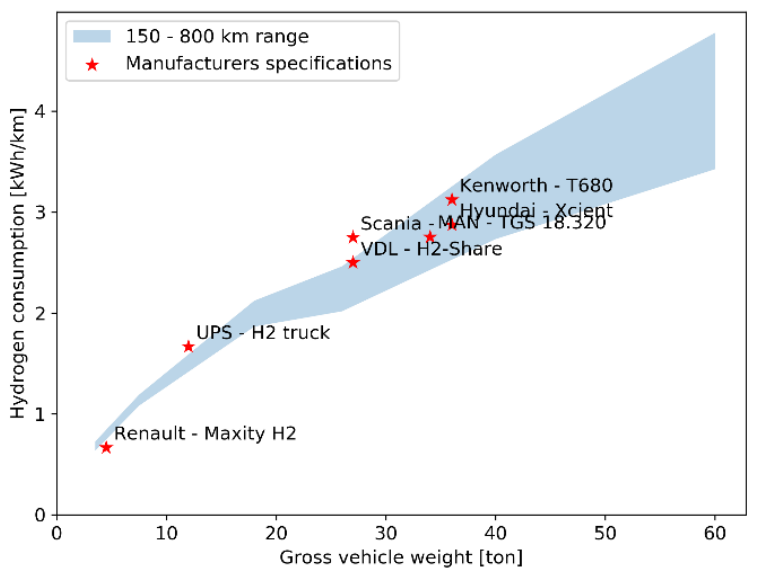

e) Hydrogen consumption per $\mathrm{km}$ and gross

vehicle weight

Figure 11 Validation against existing fuel cell electric truck models

\section{Results and discussion}

This section brings additional information to the Results section of the manuscript. 


\subsection{Truck specifications for Urban delivery driving cycle}

\begin{tabular}{|c|c|c|c|c|c|c|c|c|c|c|c|c|c|c|c|c|c|c|c|c|c|c|c|c|c|c|c|c|c|c|c|c|c|c|c|c|c|c|c|c|c|c|c|c|c|}
\hline & & & \multirow{2}{*}{$\begin{array}{c}\text { size } \\
\text { powertrain }\end{array}$} & \multicolumn{6}{|c|}{$3.5 t$} & \multicolumn{6}{|c|}{$7.5 t$} & \multicolumn{6}{|c|}{$18 \mathrm{t}$} & \multicolumn{6}{|c|}{$26 \mathrm{t}$} & \multicolumn{6}{|c|}{$32 \mathrm{t}$} & \multicolumn{6}{|c|}{$40 \mathrm{t}$} & \multicolumn{6}{|c|}{$60 \mathrm{t}$} \\
\hline & & & & BEV FC & FEEV H & HEV $d$ I IC & EEV-d I & ICEV-B P $\mathbf{P}$ & PHEV-d & $\operatorname{BEV} \mid \mathrm{F}$ & FEEV H & 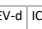 & EV-d IC & CEV-g $\left.\right|^{p}$ & HEV-d & BEV & FEEV & HEV-dII & EV-d IS & CEV-g $\left.\right|^{p}$ & HEV-d & ${ }_{B E V}$ & & IEV-d IC & EV-d IC & CEV-g t & HEV-d & BEV & & & EV-d ICE & Ev-g $\mathbf{P} \mathbf{p}$ & HEV-d & $B E V$ & & & $|C E V-d|$ & CEV-B: & PHEV-d & $\mathrm{BEV}$ & & & $d \mid C E V-d$ & $d \mid C E V-\bar{B}$ & B PHEV-d \\
\hline \multirow[t]{2}{*}{ parameter } & unit & & year & & & & & & & & & & & & & & & & & & & & & & & & & & & & & & & & & & & & & & & & & & \\
\hline & \multicolumn{2}{|c|}{ Driving indicators } & & & & & & & & & & & & & & & & & & & & & & & & & & & & & & & & & & & & & & & & & & & \\
\hline Average loading factor & unitless & & all & $60 \% 6$ & $60 \%$ & $60 \%$ & $60 \%$ & $60 \%$ & $60 \%$ & $41 \%$ & $41 \%$ & $41 \%$ & $41 \%$ & $41 \%$ & $41 \%$ & $42 \%$ & $42 \%$ & $42 \%$ & $42 \%$ & $42 \%$ & $42 \%$ & $38 \%$ & $38 \%$ & $38 \%$ & $38 \%$ & $38 \%$ & $38 \%$ & $36 \%$ & $36 \%$ & $36 \%$ & $36 \%$ & $36 \%$ & $36 \%$ & $36 \%$ & $36 \%$ & $36 \%$ & $36 \%$ & $36 \%$ & $36 \%$ & $36 \%$ & $636 \%$ & $\% 36 \%$ & $\% 36 \%$ & $\% 36 \%$ & $\% \quad 36 \%$ \\
\hline range autonomy & kilometer & & all & 150 & 150 & 150 & 150 & ${ }^{150}$ & ${ }^{150}$ & 150 & 150 & 150 & 150 & 150 & ${ }^{150}$ & ${ }^{150}$ & 150 & 150 & 150 & 150 & ${ }^{150}$ & ${ }^{150}$ & ${ }^{150}$ & 150 & 150 & 150 & 150 & 150 & ${ }^{150}$ & 150 & 150 & 150 & ${ }^{150}$ & ${ }^{150}$ & 150 & 150 & 150 & 150 & 150 & 150 & $\begin{array}{ll}0 & 150 \\
\end{array}$ & $=0155$ & $\begin{array}{ll}50 & 150 \\
\end{array}$ & $0 \quad 150$ & $50 \quad 150$ \\
\hline lifetime & year & & all & 12 & 12 & 12 & 12 & 12 & 12 & 12 & 12 & 12 & 12 & 12 & 12 & 12 & 12 & 12 & ${ }^{12}$ & 12 & 12 & 12 & 12 & 12 & 12 & 12 & 12 & 12.6 & 12.6 & 12.6 & 12.6 & 12.6 & 12.6 & 12.6 & 12.6 & 12.6 & 12.6 & 12.6 & 12.6 & 12.6 & $\begin{array}{ll}6 & 12.6 \\
\end{array}$ & $\begin{array}{ll}6 & 12.6 \\
\mathrm{C}\end{array}$ & 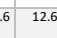 & $\begin{array}{ll}.6 & 12.6 \\
\end{array}$ & $\begin{array}{ll}.6 & 12.6 \\
\end{array}$ \\
\hline & & idicator & & & & & & & & & & & & & & & & & & & & & & & & & & & & & & & & & & & & & & & & & & & \\
\hline tank-to-wheel efficiency & unitless & 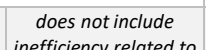 & 2020 & $75 \% 3$ & $39 \%$ & $31 \%$ & $26 \%$ & $21 \%$ & $65 \%$ & $82 \%$ & $38 \%$ & $37 \%$ & $32 \%$ & $26 \%$ & $72 \%$ & $86 \%$ & $40 \%$ & $39 \%$ & $34 \%$ & $28 \%$ & $75 \%$ & $87 \%$ & $40 \%$ & $39 \%$ & $36 \%$ & $29 \%$ & $77 \%$ & $88 \%$ & $40 \%$ & $39 \%$ & $36 \%$ & $29 \%$ & $77 \%$ & $88 \%$ & $40 \%$ & $39 \%$ & $35 \%$ & $29 \%$ & $77 \%$ & $89 \%$ & $\%$ 40\% & $\% 40 \%$ & \% $36 \%$ & $\% 30 \%$ & \\
\hline & unitless & electricity production & 2030 & $76 \% 4$ & $40 \%$ & $31 \%$ & $32 \%$ & $27 \%$ & $66 \%$ & $83 \%$ & $40 \%$ & $37 \%$ & 38\% & $33 \%$ & $72 \%$ & $86 \%$ & $41 \%$ & $39 \%$ & 40\% & $35 \%$ & $76 \%$ & $88 \%$ & ${ }^{41 \%}$ & $39 \%$ & $41 \%$ & $36 \%$ & $77 \%$ & $88 \%$ & $41 \%$ & $39 \%$ & $41 \%$ & $35 \%$ & $77 \%$ & $89 \%$ & $41 \%$ & $39 \%$ & $41 \%$ & 35\% & $78 \%$ & $90 \%$ & $\%$ & $\%$ & $\%$ & $\% 36 \%$ & $\%$ \\
\hline & unitless & & 2040 & $78 \% 4$ & $46 \%$ & $31 \%$ & $32 \%$ & $25 \%$ & $67 \%$ & $84 \%$ & $46 \%$ & $37 \%$ & $38 \%$ & $32 \%$ & $73 \%$ & $88 \%$ & $48 \%$ & $39 \%$ & 41\% & $35 \%$ & $77 \%$ & $90 \%$ & $48 \%$ & 39\% & $41 \%$ & $37 \%$ & $79 \%$ & $90 \%$ & $47 \%$ & $39 \%$ & $41 \%$ & $37 \%$ & $79 \%$ & $91 \%$ & $48 \%$ & $39 \%$ & $41 \%$ & $36 \%$ & $79 \%$ & $92 \%$ & $648 \%$ & $\% 40 \%$ & $\%$ & $\% 37 \%$ & $\%$ \\
\hline & unitless & & 2050 & $\left.78 \%\right|^{4}$ & $46 \%$ & $31 \%$ & $30 \%$ & $28 \%$ & $67 \%$ & $85 \%$ & $47 \%$ & $37 \%$ & $37 \%$ & $34 \%$ & $74 \%$ & $89 \%$ & $49 \%$ & $40 \%$ & 41\% & $37 \%$ & $78 \%$ & $91 \%$ & $49 \%$ & 39\% & $41 \%$ & $39 \%$ & $79 \%$ & $91 \%$ & $48 \%$ & $39 \%$ & $41 \%$ & $38 \%$ & $79 \%$ & $91 \%$ & $49 \%$ & $39 \%$ & $41 \%$ & $38 \%$ & $80 \%$ & $92 \%$ & $\%$ 49\% & & & $\% 40 \%$ & $\% 81 \%$ \\
\hline & & icators & & & & & & & & & & & & & & & & & & & & & & & & & & & & & & & & & & & & & & & & & & & \\
\hline combustion engine power & kilowatt & & 2020 & & 0 & 90 & 141 & 155 & 29 & 0 & 0 & 97 & 148 & 155 & ${ }^{31}$ & 0 & ${ }^{\circ}$ & 184 & 273 & 280 & 57 & 0 & 0 & 204 & 258 & 264 & 54 & 0 & 0 & 256 & 334 & 341 & 70 & & 0 & 307 & 400 & 407 & 83 & & & 35 & $54 \quad 460$ & :0 467 & 67 \\
\hline & kilowatt & & 2030 & & 0 & 81 & 70 & 87 & 26 & 0 & 0 & 86 & ${ }^{76}$ & 79 & 27 & 0 & 0 & 162 & 139 & ${ }^{143}$ & 50 & & 0 & 179 & 132 & 135 & 47 & & 0 & 256 & 196 & 199 & ${ }^{69}$ & & & 264 & 202 & 205 & 72 & & & 300 & 24233 & 3236 & \\
\hline & kilowatt & & 2040 & 0 & 0 & 74 & 70 & 108 & ${ }^{24}$ & 0 & 0 & 80 & 71 & 101 & 25 & 0 & 0 & ${ }^{151}$ & 131 & 172 & ${ }^{47}$ & 0 & 0 & ${ }^{167}$ & 124 & 140 & ${ }_{44}$ & 0 & 0 & ${ }^{254}$ & 195 & 198 & 69 & 0 & & ${ }^{241}$ & 184 & 233 & 65 & & $0^{\circ}-3+2-3$ & 278 & $78 \quad 213$ & $\begin{array}{ll}3 & 253 \\
\end{array}$ & 33 \\
\hline & kilowatt & & 2050 & 0 & 0 & 68 & 81 & 98 & 22 & 0 & 0 & 74 & 76 & 100 & 23 & 0 & 0 & 140 & 121 & 179 & 43 & 0 & 0 & 155 & 115 & 169 & 41 & 0 & 0 & 253 & 194 & 276 & 69 & & 0 & 219 & 168 & 245 & 60 & & 0 & 253 & $53 \quad 194$ & $4 \quad 281$ & 81 \\
\hline electric motor power & kilowatt & & 2020 & 120 & 120 & 45 & 0 & 0 & 95 & 130 & ${ }^{135}$ & 48 & 0 & 0 & 103 & 239 & 252 & ${ }^{83}$ & ${ }^{0}$ & 0 & 189 & 230 & ${ }^{241}$ & ${ }^{51}$ & 0 & ${ }^{0}$ & 182 & 298 & 320 & 74 & 0 & 0 & 236 & ${ }^{357}$ & 387 & 89 & 0 & 0 & 282 & 411 & $\begin{array}{ll}1 & 447 \\
\end{array}$ & $17 \quad 103$ & 03 & 0 & 0 \\
\hline & kilowatt & & 2030 & 99 & 109 & 40 & 47 & 43 & 78 & 107 & 120 & 42 & ${ }^{50}$ & 53 & 85 & 197 & 223 & 73 & ${ }_{93}$ & 95 & ${ }^{156}$ & 189 & 213 & 45 & 88 & 90 & 150 & 279 & 322 & 74 & 130 & 133 & 221 & 289 & 332 & 77 & 135 & 137 & 229 & 334 & 4386 & $\begin{array}{ll}36 & 88 \\
6\end{array}$ & $88 \quad 156$ & $\begin{array}{ll}6 & 157\end{array}$ & 264 \\
\hline & kilowatt & & 2040 & ${ }^{86}$ & 99 & ${ }^{36}$ & 39 & 18 & 68 & ${ }^{95}$ & 111 & ${ }^{39}$ & ${ }^{47}$ & 25 & 75 & 175 & 206 & 68 & ${ }^{87}$ & ${ }^{54}$ & ${ }^{139}$ & 169 & ${ }_{198}$ & ${ }^{42}$ & ${ }^{83}$ & 72 & ${ }^{134}$ & 266 & ${ }^{318}$ & 74 & 130 & 132 & 210 & 253 & 300 & 70 & 123 & 82 & 200 & 294 & 4349 & 8 & $\begin{array}{ll}81 & 142 \\
\end{array}$ & $22 \quad 108$ & 08 \\
\hline & kilowatt & & 2050 & 77 & 90 & 34 & 22 & 17 & 61 & 85 & 101 & 36 & ${ }^{34}$ & 18 & 68 & 158 & 188 & 63 & 80 & 32 & 125 & 152 & ${ }^{181}$ & 39 & 76 & 30 & 120 & 259 & 316 & 73 & 129 & 56 & 205 & 225 & 270 & 64 & 112 & ${ }^{43}$ & 178 & 261 & 1315 & & $\begin{array}{ll}73 & 129 \\
\end{array}$ & & $50 \quad 207$ \\
\hline fuel cell stack power & kilowatt & $\begin{array}{l}\text { does not add up to } \\
\text { electric motor power }\end{array}$ & 2020 & & 28 & 0 & 0 & & & 0 & 31 & 0 & 0 & 0 & 0 & 0 & 72 & 0 & 0 & 0 & & 0 & 69 & 0 & 0 & 0 & & 0 & 92 & & 0 & 0 & & 0 & 111 & 0 & 0 & 0 & & & 129 & & & & \\
\hline & kilowatt & & 2030 & 0 & 38 & 0 & 0 & 0 & 0 & 0 & ${ }^{41}$ & 0 & 0 & 0 & 0 & 0 & 90 & 0 & 0 & & & 0 & 86 & 0 & 0 & 0 & & $0^{\circ}$ & ${ }^{130}$ & 0 & 0 & & & & ${ }^{134}$ & 0 & 0 & 0 & & & 155 & & & & 0 \\
\hline & kilowatt & & 2040 & o & 33 & 0 & 0 & 0 & (c) & & 37 & 0 & 0 & 0 & 0 & 0 & 81 & 0 & 0 & & & 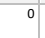 & 78 & 0 & 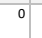 & & & 0 & 125 & & 0 & & & & ${ }^{118}$ & 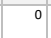 & 0 & 0 & & & 138 & & & & 0 \\
\hline & kilowatt & & 2050 & 0 & 20 & 0 & 0 & c & 0 & 0 & 23 & 0 & 0 & 0 & 0 & 0 & 53 & 0 & 0 & & & & 51 & 0 & 0 & & & 0 & 89 & & 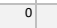 & & & & 76 & 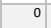 & 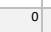 & 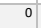 & & & 85 & & & & 0 \\
\hline & & icators & & & & & & & & & & & & & & & & & & & & & & & & & & & & & & & & & & & & & & & & & & & \\
\hline tank-to-wheel energy & kilojoule & & 2020 & 123522 & 22862 & 2896 & 3513 & 4507 & 1710 & 19333 & 3893 & 1124 & 4773 & 5963 & 2525 & 3754 & 7635 & 7907 & 9076 & 11222 & 4864 & 4339 & 8863 & 929911 & 01121 & 12480 & 5543 & 5247 & 108461 & 11231.1 & 1239915 & 5222 & 6726 & 6135 & 12847. & 13220 & 14572 & 17995 & 7895 & 8158 & 881719 & 34.1747 & $\begin{array}{lll}47 & 19147 \\
\end{array}$ & 1723598 & $98 \quad 10450$ \\
\hline & & energy use & & & & & & & & & & & & & & & & & & & & & & & & & & & & & & & & & & & & & & & & & & & \\
\hline & kilojoule & & 2030 & 1093 24 & 登3 2 & 2621 & 2513 & ${ }^{1353}$ & ${ }^{1918}$ & 1:12 & 3452 & . & 632 & $4^{4344}$ & 2250 & ${ }^{3569}$ & 6850 & 7236 & to17 & 8222 & 4882 & ${ }^{3919}$ & . & (8534 & (387 & 9464 & 5027 & 4949 & 10288 & 10988 1 & 1030612 & 2077 & 6414 & 5494 & ${ }^{11488}$ & 12011 & ${ }^{11463}$ & 13430 & 7098 & 3344 & 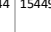 & 93986 & 8015290 & 10 17888 & $88 \quad 9437$ \\
\hline & kilojoule & & 2040 & 99016 & 16592 & 2443 & 2405 & 3122 & ${ }^{1397}$ & 1552 & 2798 & 3007 & 3220 & 4167 & 2071 & 3075 & 5588 & 6835 & 6642 & 7837 & 4056 & 3583 & ${ }^{6541}$ & 8113 & 7686 & 8720 & 4664 & 4618 & 85921 & 106021 & 1002211 & 1222 & 6092 & 4986 & 9289 & 1359 & 10812 & 12577 & 6531 & 16693 & & 78006 & 6714436 & 1616487 & 878708 \\
\hline & kilojoule & & 2050 & 895 & $14800^{2}$ & 2242 & 2370 & 2565 & ${ }^{1270}$ & 14102 & 2506 & 3229 & 3248 & 3537 & 1890 & 2843 & 5091 & 6373 & 6198 & 6814 & 3756 & 3333 & 6000 & 7610 & 7222 & 7792 & 4347 & 4404 & 80991 & 10244 & 967616 & 0531 & 5845 & 4639 & 8503 & 10637 & 10144 & 10965 & 6083 & 3625 & 57148 & $3^{1445}$ & 57 13587 & $7^{14534}$ & 348144 \\
\hline
\end{tabular}




\begin{tabular}{|c|c|c|c|c|c|c|c|c|c|c|c|c|c|c|c|c|c|c|c|c|c|c|c|c|c|c|c|c|c|c|c|c|c|c|c|c|c|c|c|}
\hline \multirow{3}{*}{ auxiliary energy } & \multirow[b]{3}{*}{ kilojoule } & & \multirow{3}{*}{\begin{tabular}{|c|} 
size \\
powertrain \\
2020 \\
\end{tabular}} & \multirow{2}{*}{\multicolumn{5}{|c|}{$\begin{array}{c}3.5 t \\
\text { 3EV FCEV HEV-d ICEV-d ICEV-B PHEV-d }\end{array}$}} & \multirow{2}{*}{\multicolumn{5}{|c|}{$7.5 t$}} & \multicolumn{5}{|c|}{$18 \mathrm{t}$} & \multicolumn{5}{|c|}{$26 t$} & \multicolumn{5}{|c|}{$32 t$} & \multicolumn{5}{|c|}{$40 \mathrm{t}$} & \multicolumn{6}{|c|}{$60 \mathrm{t}$} \\
\hline & & & & & & & & & & & & & HEV-d BE & & & & ICEV-B PH & SHEV-d BE & BEV FC & CEV HEV - & $|-d|$ |CEV-d & $\mid$ ICEV-g P & PHEV-d Bt Bt & \begin{tabular}{l|l}
$\mathrm{BEV}$ & $\mathrm{FCE}$ \\
\end{tabular} & & d I ICEV-d & CEV-B $\mathrm{B}$ P & PHEV-d & BEV & $\mathrm{FeEV}$ He & EV-dICE & $N-d$ ICEY & N-B PHE & $\mathrm{ND}-\mathrm{d}$ BE & & & d I ICEV-C & d| ICEV- & P PHEV. \\
\hline & & & & 133128 & 128 & ${ }^{128}$ & 128 & 132 & 268257 & 257 & 257 & 257 & 266 & $546 \quad 51$ & 18518 & 518 & 518 & $540=$ & 595 & 55555 & 55555 & 555 & 587 & 6756 & 13613 & $\begin{array}{ll}3 & 613 \\
\end{array}$ & ${ }^{613}$ & 662 & 675 & 614 & 614 & $614 \quad 6$ & 614 & \begin{tabular}{l|l}
662 & 8 \\
\end{tabular} & 88382 & $22 \quad 822$ & 82 & 82 & 2287 \\
\hline & kilojoule & & 2030 & 127122 & 122 & 122 & 122 & 126 & 256244 & 244 & ${ }^{244}$ & ${ }^{244}$ & 254 & 52149 & $94 \quad 494$ & $4 \quad 494$ & 494 & $516=$ & 569 & 52952 & 29529 & 529 & 561 & $647 \quad 58$ & 86586 & 6586 & ${ }^{586}$ & ${ }^{634}$ & ${ }^{647}$ & 586 & 586 & 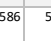 & 586 & $\begin{array}{ll}634 & 8 \\
\end{array}$ & $845 \quad 78$ & $\begin{array}{ll}84 & 78 . \\
\end{array}$ & $\begin{array}{ll}34 & 78 . \\
7\end{array}$ & $\begin{array}{l}478 \\
78\end{array}$ & $84 \quad 83$ \\
\hline & kilojoule & & 2040 & 119115 & 115 & 115 & 115 & ${ }^{118}$ & 239230 & 230 & 230 & 230 & 237 & $485 \quad 46$ & $64 \quad 464$ & $4 \quad 464$ & 464 & $481=$ & 526 & $495 \quad 49$ & $95 \quad 495$ & 495 & 519 & 5925 & $45 \quad 545$ & $15 \quad 545$ & 545 & 582 & 592 & 545 & 545 & 5455 & 545 & 5827 & $780 \quad 73$ & $33 \quad 73$ & $33^{73}$ & 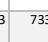 & $\begin{array}{ll}33 & 77 \\
\end{array}$ \\
\hline & kilojoule & & 2050 & 113109 & 109 & 109 & 109 & 112 & 228219 & 219 & 219 & 219 & 226 & $463 \quad 44$ & $42 \quad 442$ & $\begin{array}{l}2442 \\
4\end{array}$ & 442 & $458=$ & 502 & $472 \quad 47$ & $72 \quad 472$ & 472 & 496 & \begin{tabular}{l|l}
567 & 5 \\
5
\end{tabular} & $\begin{array}{l}20 \\
2020\end{array}$ & 50 & 520 & 557 & ${ }^{567}$ & 520 & 520 & 520 & 520 & 557 & 69 & 99699 & 69. & 695 & 9973 \\
\hline electricity consumption & kilowatt hour per kilometer & & 2020 & 0.400 .00 & 0.00 & 0.00 & 0.00 & 0.32 & 0.630 .00 & 0.00 & 0.00 & 0.00 & 0.501 & $1.23 \quad 0.0$ & $\begin{array}{ll}00 & 0.00 \\
\end{array}$ & $\begin{array}{l}0.00 \\
0\end{array}$ & 0.00 & 0.971 & 1.420 & $0.00 \quad 0.0$ & 000.00 & 0.00 & 1.121 & $1.71 \quad 0.0$ & $.00 \quad 0.00$ & 100.00 & 0.00 & ${ }^{1.36}$ & 2.01 & 0.00 & 0.00 & .000 & .00 & $\begin{array}{ll}1.59 & 2 . \\
\end{array}$ & & $00 \quad 0.00$ & 00.0 & $\begin{array}{l}0 \\
0.00\end{array}$ & $00 \quad 2.1 .1$ \\
\hline & kilowatt hour per kilometer & & 2030 & 0.360 .00 & 0.00 & 0.00 & 0.00 & 0.28 & 0.560 .00 & 0.00 & 0.00 & 0.00 & 0.44 & $1.10 \quad 0.0$ & 000.00 & 0.00 & 0.00 & \begin{tabular}{l|l}
0.87 & 1
\end{tabular} & 1.280 & $0.00 \quad 0.0$ & 000.00 & 0.00 & 1.011 & $1.62 \quad 0.6$ & .000 .00 & $\begin{array}{ll}0 & 0.00 \\
\end{array}$ & 0.00 & ${ }^{1.28}$ & ${ }^{1.80}$ & $0.00 \mathrm{C}$ & $0.00 \quad 0$ & .000 & .00 & $\begin{array}{ll}1.42 & 2 . \\
\end{array}$ & $.40 \quad 0.0$ & $00 \quad 0.00$ & 0.00 & 0.00 & $00 \quad 1.9$ \\
\hline & kilowatt hour per kilometer & & 2040 & 0.320 .00 & 0.00 & 0.00 & 0.00 & 0.25 & 0.500 .00 & 0.00 & 0.00 & 0.00 & 0.40 & 0.990 .0 & 000.00 & 0.00 & 0.00 & $0.78{ }^{1}$ & 1.150 & 0.000 .0 & 000.00 & 0.00 & $0.911^{1}$ & 1.490 .5 & .000 .00 & 100.00 & 0.00 & 1.18 & 1.61 & 0.00 & 0.000 & 500 & .001 & 1.272. & .150 .0 & 000.00 & 500.0 & 00.00 & $00 \quad 1.7$ \\
\hline & kilowatt hour per kilometer & & 2050 & 0.290 .00 & 0.00 & 0.00 & 0.00 & 0.23 & 0.450 .00 & 0.00 & 0.00 & 0.00 & 0.36 & $0.92 \quad 0.0$ & 000.00 & 0.000 & 0.00 & 0.721 & 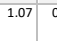 & 0.000 .0 & 000.00 & 0.00 & $0.855^{1}$ & $1.42 \quad 0.0$ & .000 .00 & $\begin{array}{ll}0 & 0.00 \\
\end{array}$ & 0.00 & 1.12 & ${ }^{1.49}$ & $0.00 \mathrm{C}$ & $0.00 \quad 0$ & .000 & .00 & $\begin{array}{l}.18 \\
2 .\end{array}$ & .010 .0 & 000.00 & 0.00 & 0.00 & $00 \quad 1.5$ \\
\hline fuel consumption & gram per kilometer & & 2020 & 19 & 68 & 82 & 81 & 17 & 32 & 97 & 112 & 107 & ${ }^{23}$ & 6 & $\begin{array}{ll}64 & 186\end{array}$ & 213 & 202 & ${ }^{44}$ & 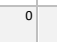 & $74 \quad 21$ & $\begin{array}{ll}18 & 237\end{array}$ & 225 & 50 & & $90 \quad 264$ & $4 \quad 290$ & 274 & 60 & & 107 & 310 & $3423^{3}-x-3$ & 324 & 71 & 14 & $43 \quad 41$ & 45 & ${ }^{42}$ & 25 \\
\hline & gram per kilometer & & 2030 & ${ }^{17}$ & 62 & 60 & 56 & 16 & 29 & 89 & 86 & 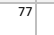 & 21 & 0 & $57 \quad 172$ & 167 & 148 & 41 & 0 & $67 \quad 20$ & $\begin{array}{ll}03 & 192 \\
\end{array}$ & 171 & 46 & ${ }^{0}$ & $\begin{array}{ll}86 & 259 \\
\end{array}$ & $\begin{array}{l}9 \\
9\end{array}$ & 218 & ${ }^{59}$ & 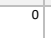 & 96 & 287 & 272 & 242 & 65 & 12 & 375 & 36: & 322 & 8 \\
\hline & gram per kilometer & & 2040 & 14 & 58 & 57 & 56 & 15 & 23 & 84 & 82 & 75 & 20 & 0 & $\begin{array}{ll}47 & 163 \\
\end{array}$ & $\begin{array}{l}358 \\
\end{array}$ & 141 & 39 & 0 & $\begin{array}{ll}55 & 19 \\
\end{array}$ & $\begin{array}{ll}93 & 183 \\
\end{array}$ & 157 & 44 & 0 & $\begin{array}{ll}72 & 253\end{array}$ & $\begin{array}{ll}3 & 239\end{array}$ & 202 & 58 & 0 & 77 & 271 & 258 & 226 & 62 & 10 & 35. & 34 & 29 & 8 \\
\hline & gram per kilometer & & 2050 & $\begin{array}{lll}0 & 12\end{array}$ & 54 & 57 & ${ }^{46}$ & ${ }^{14}$ & ${ }^{21}$ & 78 & 78 & ${ }^{64}$ & 19 & 04 & $42 \quad 154$ & ${ }^{150}$ & ${ }^{123}$ & ${ }^{36}$ & 0 & $\begin{array}{lll}50 & 18 \\
\end{array}$ & $84 \quad 174$ & 140 & 41 & s & $67 \quad 247$ & $17 \quad 234$ & ${ }^{190}$ & 57 & & ${ }^{71}$ & 257 & 2451 & 198 & & & $96 \quad 34$ & 1232. & 26. & 627 \\
\hline & Mass indic & cators & & & & & & & & & & & & & & & & & & & & & & & & & & & & & & & & & & & & & \\
\hline curb mass & kilogram & & 2020 & 22691818 & 2043 & 2137 & 2343 & 22414 & 42613547 & 3810 & 3900 & 4087 & $\begin{array}{ll}4186 \quad 8 . \\
\end{array}$ & 8530720 & 007631 & 1788 & 7996 & 8375 95 & 99018 & 8324878 & 378880 & 9087 & 968813 & 30741121 & 1711591 & 11729 & 11955 & 12794 & 15931 & 1382014 & 4126 & 290145 & $\begin{array}{lll}538 & 15 . & \\
\end{array}$ & 589233 & 3452033 & 382073 & 32091 & 921205 & $05 \quad 2283$ \\
\hline & kilogram & & 2030 & 18691653 & 1829 & ${ }^{1763}$ & 1967 & 18683 & 35233163 & 3376 & 3313 & 3484 & 35007 & 7019635 & 576723 & 6639 & 6816 & \begin{tabular}{l|l}
6977 & 8.
\end{tabular} & 81587 & 7342773 & 31 7607 & 7783 & 807712 & 2225113 & 0311586 & 611445 & 11634 & 121101 & 12897 & 1184712 & 215512 & 012122 & & 762189 & 9581733 & $3991783 \mathrm{C}$ & 30 1767: & 917894 & 941874 \\
\hline & kilogram & & 2040 & 16251999 & 1668 & 1650 & 1895 & $16500^{3}$ & 31252915 & 3128 & 3101 & 3322 & 31416 & 6256588 & 836264 & 4215 & 6458 & 628472 & 72796 & $6811 \quad 721$ & $\begin{array}{ll}18 & 7128\end{array}$ & 7322 & 728211 & 1660111 & 7511492 & 211379 & 11561 & 116531 & 11298 & 1071511 & 108610 & 978112 & $244 \quad 11$ & 281166 & 6811588 & 366 & 21617 & 16436 & 361663 \\
\hline & kilogram & & 2050 & 14531365 & 1540 & 1555 & 1755 & 14842 & 28092670 & 2891 & 2885 & 3089 & 28395 & 5625538 & 835789 & 5745 & 60085 & $\begin{array}{ll}5682 & 65 \\
\end{array}$ & 65506 & $6244 \quad 666$ & $68 \quad 6589$ & 6844 & 658811 & $1377110 \mathrm{~s}$ & 19011455 & is 11350 & 11656 & 114201 & 10037 & 965610 & 0081 & 986102 & $287 \quad 10$ & 068148 & 8471332 & 2514881 - & 1471 & 15041 & 411486 \\
\hline available payload & kilogram & & 2020 & 11561607 & 1382 & 1288 & 1082 & $11844^{3}$ & 31643878 & 3615 & 3525 & 3338 & 323999 & 93951072 & 2510294 & 10137 & \begin{tabular}{|c|c|}
9929 & 9
\end{tabular} & 9550166 & $160244^{17}$ & 76011713 & 3817045 & 16838 & 1623718 & 8851207 & 10820334 & 420196 & 19970 & & 23994 & 2610525 & 5799 & 635253 & & 336365 & 5803958 & 8773919 & 223900 & 638720 & 203708 \\
\hline & kilogram & & 2030 & 15561772 & 1596 & 1662 & 1458 & 1557 & 39024262 & 4049 & 4112 & 3941 & 3925100 & 09061156 & 6811202 & 211286 & $11109{ }_{10}^{10} \mathrm{Cl}$ & 1094817 & 176718 & 85831819 & 84 18318 & 18142 & 1784819 & 97002065 & 22220339 & 920480 & 20291 & 198152 & 27028 & 2807827 & & 913277 & & 163409 & 9674338 & 8664209 & 54224 & 164203 & 314117 \\
\hline & kilogram & & 2040 & 18001926 & 1757 & 1775 & 1530 & 17754 & 43004510 & 4297 & 4324 & 4103 & 428411 & 16691204 & 4211661 & 11710 & 114671 & 11641186 & 1864619 & 91141870 & 0718797 & 18603 & 1864320 & 02652075 & 75020433 & 320546 & 20364 & 202722 & 28627 & 2921028 & 8839 & 947286 & 68128 & 644432 & 2444003 & 399 4363. & 44375 & 224348 & 894329 \\
\hline & kilogram & & 2050 & 19722060 & 1885 & 1870 & 1670 & 19414 & 46164755 & 4534 & 4540 & 4336 & 458612 & 23001254 & 4212136 & 12280 & $1917 \mathrm{I}^{12}$ & 12243199 & 1937519 & 96811925 & 5719336 & 19081 & 1933720 & 0548208 & 33520470 & 020575 & 20269 & 205052 & 29888 & 3026929 & 984429 & 939296 & 63829 & 857450 & 0784560 & 5004510 & 364521 & 104488 & 844505 \\
\hline payload & kilogram & $\begin{array}{l}\text { based on loading } \\
\text { factor }\end{array}$ & 2020 & 696967 & 832 & 776 & 651 & 7131 & 12911582 & 1475 & 1438 & 1362 & 1322 & 3983454 & 484365 & 5298 & 42104 & 40496 & 61056 & $6706 \quad 653$ & $30 \quad 6994$ & 6415 & 61866 & $\begin{array}{ll}6786 & 745 \\
5\end{array}$ & 4557320 & $\begin{array}{ll}0 & 7271\end{array}$ & 7189 & 6887 & 8590 & $9346 \mathrm{~g}$ & 9236 & 17790 & & 712130 & & 1721003 & 1396. & 13862 & 621327 \\
\hline & kilogram & & 2030 & 9371067 & 961 & 1001 & 878 & 1 937 & 15921739 & 1652 & 1678 & 1608 & 16014 & 4624490 & 054750 & 4785 & $4710 \mathrm{4}$ & $\begin{array}{ll}4642 & 6 \\
\end{array}$ & 67697 & 7080693 & 326979 & 6912 & 68007 & 7092742 & 24247322 & 27373 & 7305 & 7133 & & 100529 & 9941 & 99399 & 923 & 724146 & 517 & 1507 & 1512 & 1504 & 47.1774 \\
\hline & kilogram & & 2040 & 1159 & 1057 & 1068 & ${ }^{921}$ & 1069 & 1840 & 1753 & 1764 & 1674 & 1748 & 4948510 & $06 \quad 4944$ & 4965 & \begin{tabular}{|l|l}
4862 & 4 \\
\end{tabular} & $\begin{array}{lll}4936 & 71 \\
\end{array}$ & 7104 & $\begin{array}{ll}7282 & 712 \\
\end{array}$ & 277162 & 7088 & 71037 & 7295747 & 4707356 & $\begin{array}{ll}67396 \\
\end{array}$ & 7331 & & & & & 363102 & & 255154 & & 1661562 & 11566 & 31556 & 691550 \\
\hline & kilogram & & 2050 & 18871240 & 1135 & 1126 & 1006 & 11691 & 18831990 & 1850 & 1852 & 1769 & 18715 & 5215531 & 185146 & 5164 & 5053 5 & $5191 \quad 7$ & 73827 & 7499733 & 377367 & 7270 & 73677 & 7397755 & 5007369 & 97007 & 7297 & 73821 & 10700 & 1083610 & 068410 & 718106 & & 689161 & 1381632 & 25 1614: & 181618 & 2516065 & 691613 \\
\hline driving mass & kilogram & includes driver's mass & 2020 & 30402860 & 2950 & 2987 & 3069 & $3029 \mathrm{~s}$ & 56275204 & 5360 & ${ }^{5413}$ & 5524 & 558212. & 25891182 & 2212071 & $\left.122161\right|^{1}$ & 1228112 & 12499166 & 1008115 & 51051539 & p11 15499 & 15577 & 1595019 & 9936187 & 74718986 & 6 60074 & 19219 & 197562. & 24596 & 2324023 & 333723 & 542237 & & 376365 & 5153458 & 3553833 & 193995. & 8835142 & 423619 \\
\hline & kilogram & & 2030 & 28812795 & 2865 & 2838 & 2920 & 28805 & 51904977 & 5103 & 5066 & 5167 & 517711 & 17181133 & 371548 & 114991 & 116011 & 11694150 & 1500214 & 49971473 & 3814661 & 1470 & 1495219 & 93921880 & 80218983 & 318893 & 19014 & 193192 & 22648 & 21974 & 2172 & 080222 & & & 6993278 & $1883297 \mathrm{4}$ & 3287: & 33016 & 16 3356 \\
\hline & kilogram & & 2040 & $2784{ }^{2734}$ & 2801 & 2794 & 2891 & 27934 & 49544830 & 4956 & 4990 & 5071 & 496411 & 12781106 & 1641283 & $\left.11255\right|^{1}$ & 113955 & 1129514 & 1445814 & 41681442 & 2014365 & 14485 & 1446019 & 9031187 & 72018923 & $3^{18851}$ & 18967 & & 21621 & 2124721 & 1486 & 416215 & & 610322 & 2373172 & 3198 & 3191 & 3208 & 803220 \\
\hline & kilogram & & 2050 & 27152680 & 2750 & 2756 & 2835 & 272 & 4685 & 4816 & 4813 & 4933 & 478510 & 09151077 & 7611009 & 109841 & $1113610 \mathrm{Cl}$ & $1094814 \mathrm{C}$ & 1400713 & 38171408 & 3014031 & 14189 & 1403018 & 88501866 & 66618899 & 918832 & 19028 & 1887 & 208 & 205 & 0846 & 179209 & $972 \quad 20$ & & & 1048 & 3097 & 3118 & 843107 \\
\hline energy battery mass & kilogram & included in curb mass & 2020 & 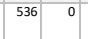 & 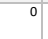 & 0 & & & 83 & & & & 6641 & 1630 & & & & 122018 & 1883 & & & & $1490 \mathrm{~F}^{2}$ & 227 & & & & 18022 & 2663 & & & & & 10835 & & & & & 280 \\
\hline & kilogram & & 2030 & $316 \quad 0$ & ${ }^{0}$ & 0 & & 250 & 496 & 0 & & & 392 & 975 & & & & 7721 & 1134 & 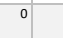 & & & 8971. & 1432 & & & & 1133 & 1590 & & & 0 & 1 & 25821 & & & & & 168 \\
\hline
\end{tabular}




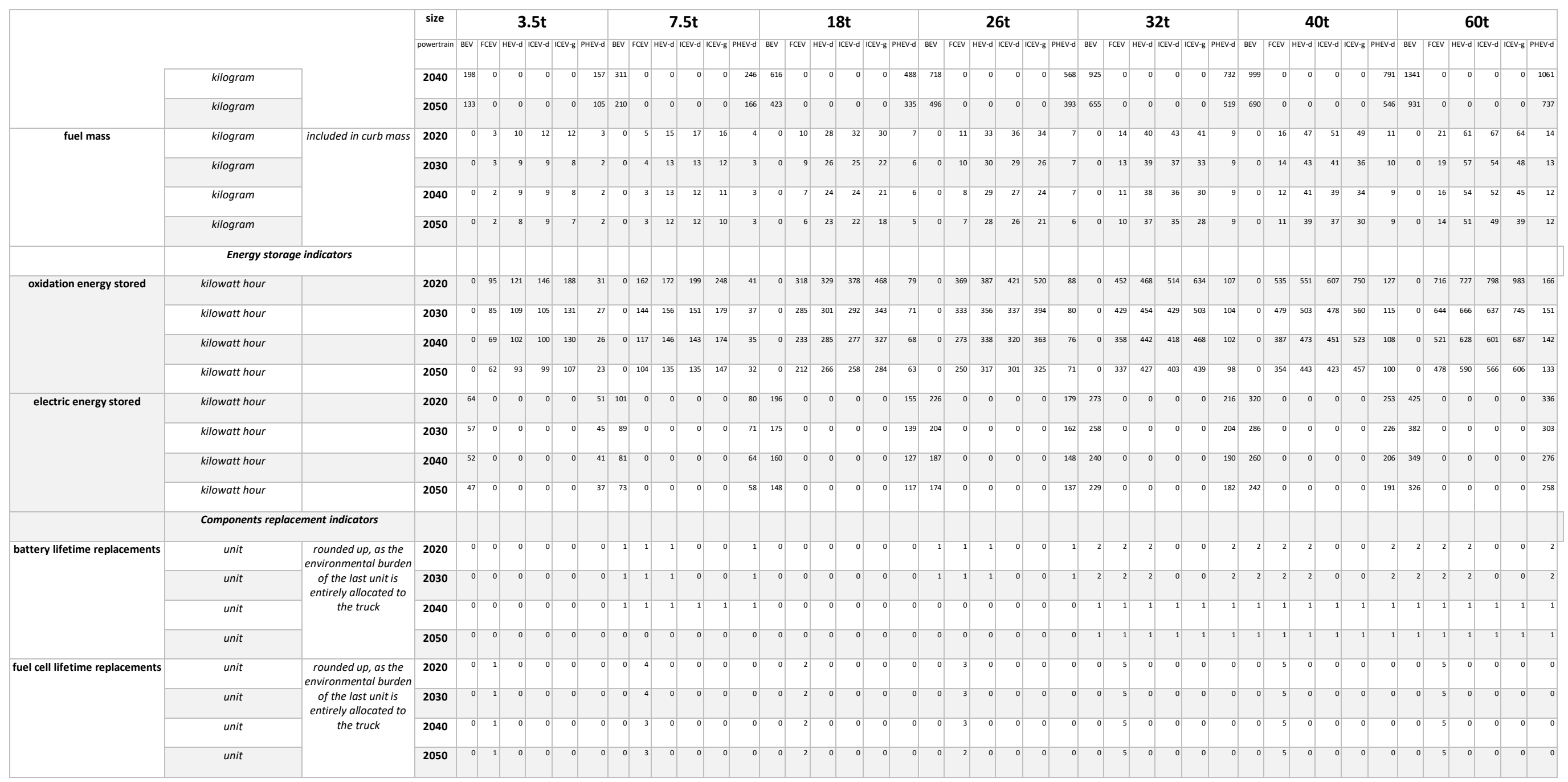




\subsection{Truck specifications for Regional delivery driving cycle}

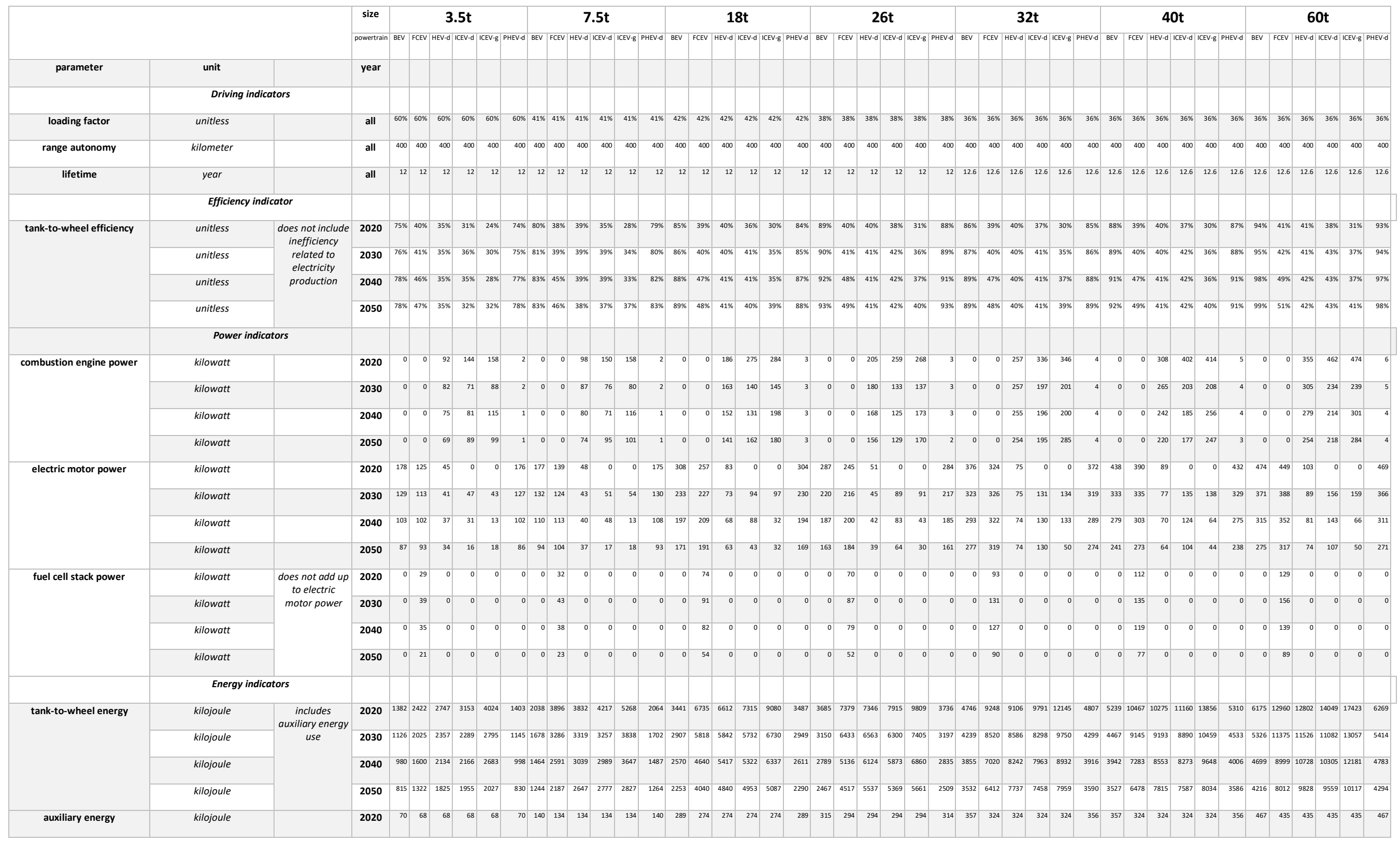




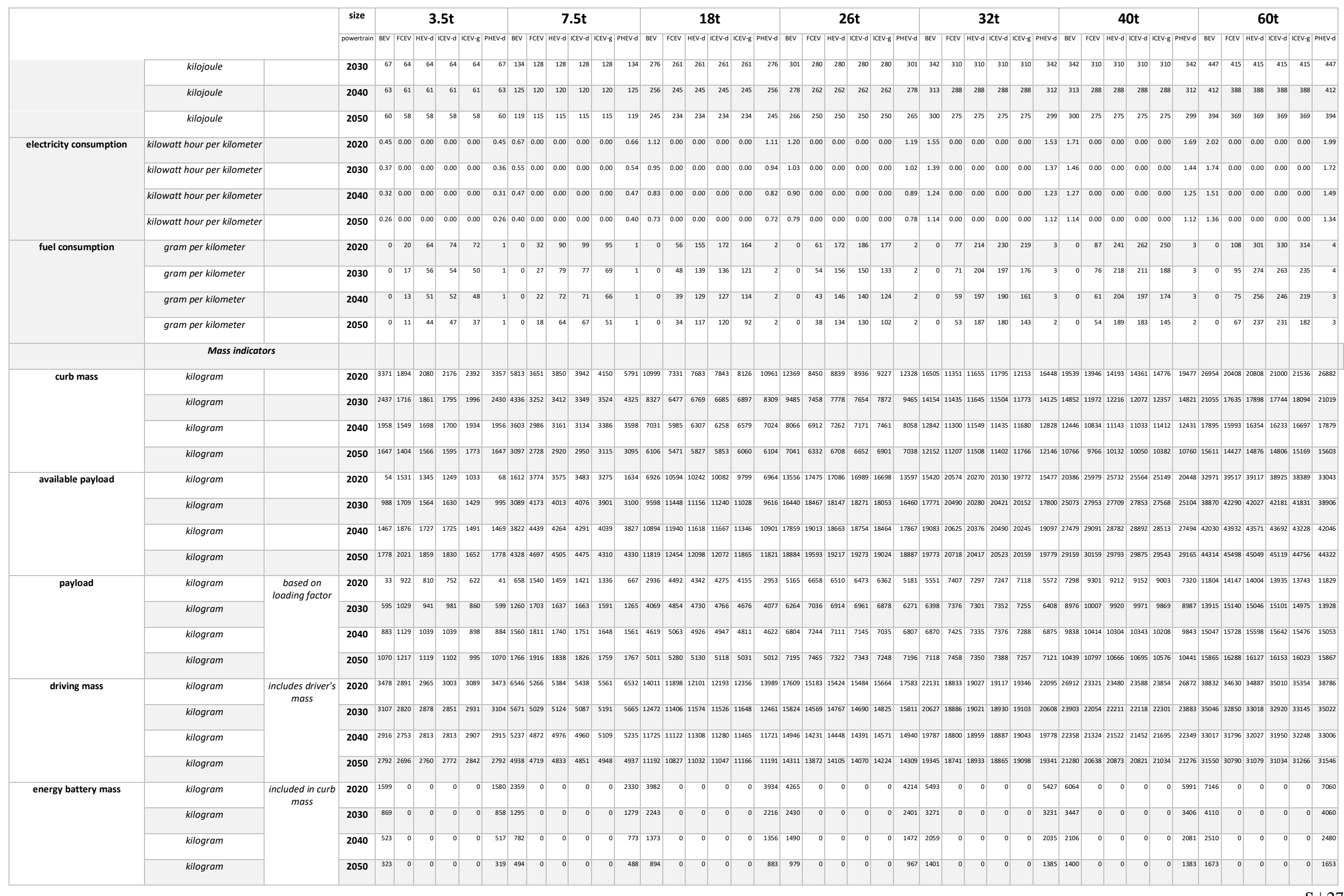




\begin{tabular}{|c|c|c|c|c|c|c|c|c|c|c|c|c|c|c|c|c|c|c|c|c|c|c|c|c|c|c|c|c|c|c|c|c|c|c|c|c|c|c|c|c|c|c|}
\hline & & & size & & & 3. & & & & & & $7.5 t$ & & & & & 18 & & & & & & 26 & & & & & 32 & & & & & & $40 t$ & & & & & & $60 t$ & & \\
\hline & & & powertra & BEV & FCEV H & EV-d I & 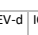 & $E-B||^{-1}$ & & $\mathrm{BEV} / \mathrm{FCE}$ & EV HEV-C & $-d$ I CEV-d & 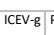 & PHEV-d & $\mathrm{BEV}$ & FCEV & HEV-dI & Ev-du & CEV-g P $^{2}$ & PHEV-d & BEV & FCEV H & HEV-d IC & $\mathrm{CEV}-\mathrm{d} \mid \mathrm{CEE}$ & CEV-g PHEV-C & $B E V$ & FCEV $\mid$ & $|\mathbb{E V - d}| \mathrm{IC}$ & EV-DICEE & EV-B PH: & & BEV & FCEV H H & $E-D \mid C E E$ & 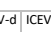 & V.P PHEV & $\begin{array}{ll}\mathrm{E}-\mathrm{d} & \mathrm{BEV}\end{array}$ & & CEV $/$ HEV-C & $d \mid C E V-d$ & I CEV-B & B PHEVV.d \\
\hline fuel mass & kilogram & $\begin{array}{l}\text { included in curb } \\
\text { mass }\end{array}$ & 2020 & & 8 & 26 & 30 & 29 & & & 13 & $\begin{array}{ll}36 & 40 \\
\end{array}$ & 38 & 0 & 0 & 22 & 62 & 69 & 65 & & & 25 & 69 & 74 & & & 31 & 86 & 92 & 88 & & & 35 & & $105 \quad 1$ & & & & \begin{tabular}{l|l}
43 & 120 \\
\end{tabular} & 132 & 2126 & \\
\hline & kilogram & & 2030 & 0 & 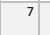 & 22 & 22 & 20 & & 0 & $11 \quad 32$ & 3231 & 28 & 0 & 0 & 19 & 55 & ${ }^{54}$ & 49 & & 0 & 21 & 62 & 60 & 53 & 0 & ${ }^{28}$ & 82 & 79 & 70 & & 0 & 30 & 87 & 84 & & & & $\begin{array}{ll}38 & 109 \\
\quad\end{array}$ & 105 & 94 & \\
\hline & kilogram & & 2040 & 0 & 5 & 20 & ${ }^{21}$ & 19 & & 0 & $9 \quad 29$ & $29 \quad 29$ & 26 & 0 & 0 & 15 & 52 & ${ }^{51}$ & 46 & 1 & 0 & 17 & 58 & 56 & 49 & 0 & ${ }^{23}$ & 79 & 76 & 64 & & 0 & 24 & 82 & 79 & 70 & & 3 & \begin{tabular}{l|l}
30 & 102 \\
$\quad$
\end{tabular} & 98 & 88 & 88 \\
\hline & kilogram & & 2050 & 0 & 4 & 18 & 19 & 15 & & 0 & 726 & $26 \quad 27$ & 20 & 0 & 0 & 13 & 47 & 48 & 37 & 1 & 0 & 15 & ${ }^{53}$ & 52 & ${ }^{41}$ & 0 & ${ }^{21}$ & 75 & 72 & 57 & & 0 & 22 & 75 & 73 & 58 & & ${ }^{2}$ & \begin{tabular}{l|l}
27 & 95 \\
\end{tabular} & 92 & 73 & \\
\hline & Energy storc & ndicators & & & & & & & & & & & & & & & & & & & & & & & & & & & & & & & & & & & & & & & & \\
\hline & kilowatt hour & & 2030 & 0 & 225 & 262 & 254 & 311 & & ${ }^{36}$ & 65369 & 69362 & ${ }^{426}$ & ${ }^{5}$ & 0 & ${ }^{646}$ & 649 & 637 & 748 & 9 & ${ }^{0}$ & 715 & 729 & 700 & ${ }^{823}$ & 0 & 947 & ${ }^{954}$ & $922{ }^{1}$ & 1083 & ${ }^{12}$ & 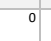 & 1016 & 1021 & $988{ }^{11}$ & & 13 & ${ }^{126}$ & $264 \quad 1281$ & 1231 & 1451 & \\
\hline & kilowatt hour & & 2040 & 0 & 178 & 237 & 241 & 298 & & 28 & 88338 & $88 \quad 332$ & 405 & 4 & 0 & 516 & 602 & 591 & 704 & 8 & 0 & 571 & 680 & 653 & 762 & 0 & 780 & 916 & 885 & 992 & 12 & 0 & 809 & 950 & 81910 & & 12 & 100 & $000 \quad 1192$ & 1145 & 1353 & \\
\hline & kilowatt hour & & 2050 & 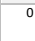 & 147 & 203 & 213 & 22 & & 24 & $43 \quad 294$ & $34 \quad 309$ & 314 & ${ }^{4}$ & ${ }^{0}$ & 449 & 538 & 550 & 565 & 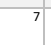 & ${ }^{0}$ & 502 & 615 & 597 & 629 & 0 & 712 & 860 & 829 & 884 & ${ }^{11}$ & ${ }^{\circ}$ & 720 & 868 & 343 & & & & 8901092 & 1062 & 1124 & \\
\hline electric energy stored & kilowatt hour & & 2020 & 192 & 0 & & & & & 283 & & & & 280 & 478 & & 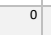 & & & 472 & 512 & & 0 & & 50 & 5659 & & & 0 & & 651 & 728 & & & ( & & $\begin{array}{l}719 \\
715\end{array}$ & 858 & & 0 & 0 & \\
\hline & kilowatt hour & & 2030 & 156 & 0 & 0 & & 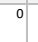 & 155 & 233 & 0 & & o & 230 & ${ }^{404}$ & 0 & 0 & & 0 & 399 & 437 & 0 & 0 & & 432 & 2589 & 0 & 0 & 0 & & 582 & 620 & 0 & & 0 & & $\begin{array}{ll}613 & 74 \\
\end{array}$ & 740 & & 0 & & \\
\hline & kilowatt hour & & 2040 & 136 & 0 & ${ }^{0}$ & & & 134 & 203 & 0 & & & 201 & 357 & 0 & 0 & & o & 353 & 387 & 0 & 0 & & 383 & $\begin{array}{ll}3 & 535 \\
\end{array}$ & & 0 & 0 & & 529 & 548 & 0 & 0 & 0 & 5 & 54165 & 653 & & & & \\
\hline & kilowatt hour & & 2050 & 113 & 0 & ${ }^{0}$ & & & 112 & 173 & 0 & & 0 & 171 & 313 & 0 & 0 & & 0 & 309 & 343 & 0 & 0 & & 339 & $\begin{array}{l}9 \\
941\end{array}$ & 0 & ${ }_{0}^{\circ}$ & & & 485 & 490 & 0 & & & & & 586 & & & & 578 \\
\hline & Components replc & ent indicators & & & & & & & & & & & & & & & & & & & & & & & & & & & & & & & & & & & & & & & & \\
\hline battery lifetime replacements & unit & rounded up, as & 2020 & o & 0 & ${ }^{\circ}$ & & s. & & & & & 0 & 1 & 0 & 0 & 0 & 0 & 0 & ${ }^{0}$ & 1 & 1 & 1 & & 0 & & 2 & & 0 & & & & 2 & & c & & & & & ${ }^{0}$ & 0 & 0 \\
\hline & unit & environmental & 2030 & 0 & 0 & 0 & & & & & & & & 1 & 0 & 0 & 0 & & 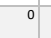 & 0 & 1 & 1 & 1 & & 0 & & & & 0 & & & & & & c & & & & & 0 & 0 & 0 \\
\hline & unit & last unit is & 2040 & 0 & 0 & 0 & & 0 & & & 1 & & 1 & 1 & 0 & 0 & 0 & & 0 & 0 & 0 & 0 & 0 & & 0 & 1 & 11 & 1 & 1 & & & 1 & 1 & & 1 & & & 1 & & 1 & 1 & \\
\hline & & & & & 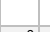 & & & & & . & ce & & & 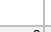 & & & & & & & & & & & & & & & & & & & & & & & & & & & & \\
\hline & unit & $\begin{array}{l}\text { allocated to the } \\
\text { truck }\end{array}$ & 2050 & 0 & 0 & 0 & & & & & & & & 0 & 0 & & & & & 0 & & & & & & & & & & & & & & & & & & & & 1 & & \\
\hline fuel cell lifetime replacements & unit & rounded up, as & 2020 & 0 & 0 & ${ }^{\circ}$ & & & & & 2 & & & 0 & 0 & & 0 & & s & 0 & & & 0 & & & & 3 & & 0 & & & & ${ }^{3}$ & & & & & & & 0 & 0 & \\
\hline & unit & environmental & 2030 & 0 & 0 & 0 & & & & 0 & 2 & & & 0 & 0 & 1 & 0 & & & 0 & 0 & 1 & 0 & & 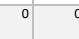 & & ${ }^{3}$ & 0 & 0 & & & & ${ }^{3}$ & & 0 & & & & & 0 & & \\
\hline & unit & last unit is & 2040 & 0 & 0 & 0 & & & & & & & & 0 & 0 & 1 & 0 & & & & 0 & 1 & 0 & & & & & & 0 & & & & 3 & & 0 & & & & & 0 & 0 & \\
\hline & unit & $\begin{array}{l}\text { entirely } \\
\text { allocated to the }\end{array}$ & 2050 & & 0 & 0 & & & & & & & & & 0 & & 0 & & & & & & 0 & & & & & & 0 & & & & & & 0 & & & & & 0 & 0 & \\
\hline & & truck & & & & & & & & & & & & & & & & & & & & & & & & & & & & & & & & & & & & & & & & \\
\hline
\end{tabular}




\subsection{Truck specifications for Long haul driving cycle}

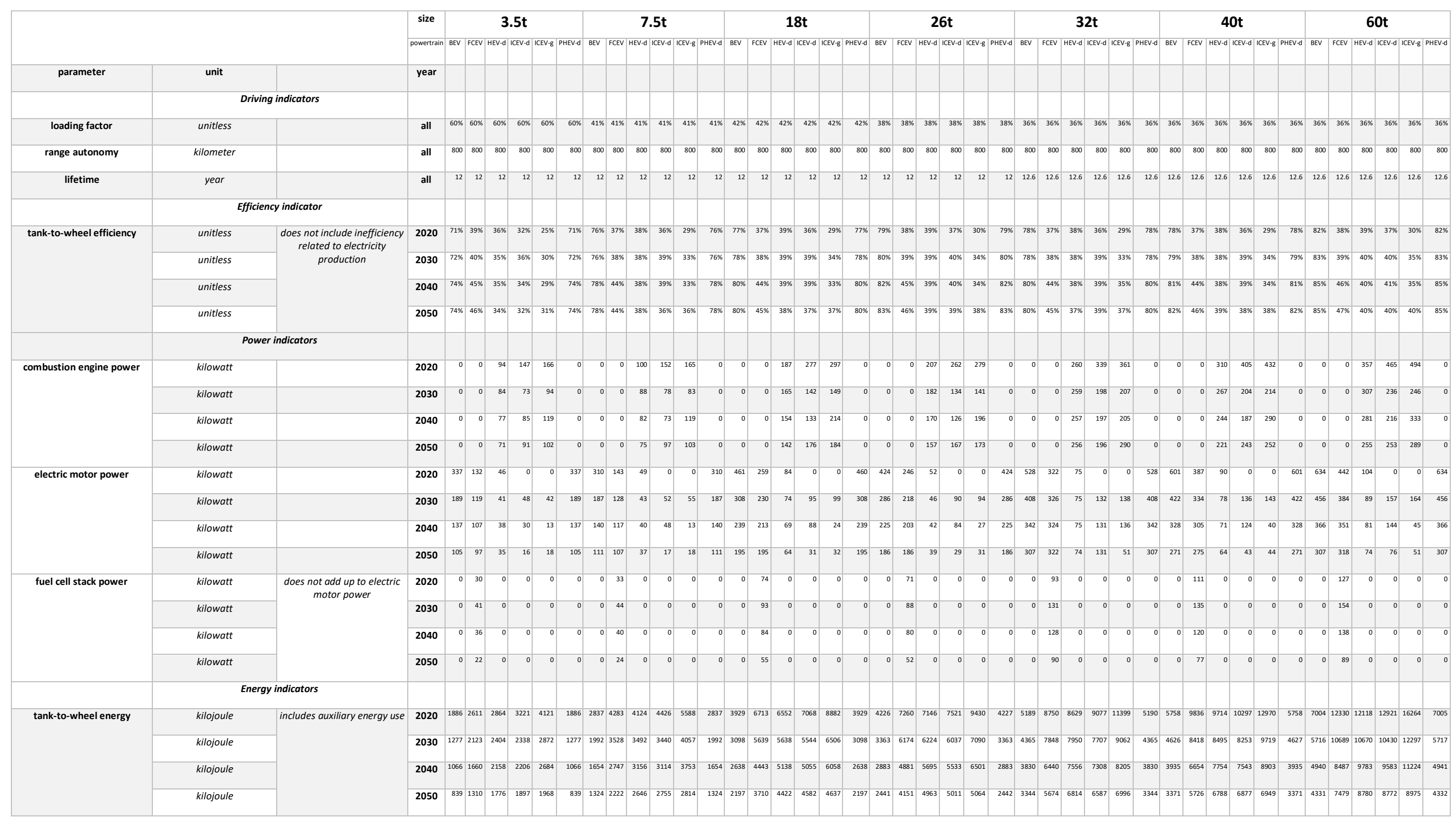




\begin{tabular}{|c|c|c|c|c|c|c|c|c|c|c|c|c|c|c|c|c|c|c|c|c|c|c|c|c|c|c|c|c|c|c|c|c|c|c|c|c|c|c|c|c|c|}
\hline \multirow{3}{*}{ auxiliary energy } & \multirow[b]{3}{*}{ kilojoule } & & \multirow{3}{*}{\begin{tabular}{|c|c|} 
size & \\
powertrain & \\
2020 &
\end{tabular}} & \multirow{2}{*}{\multicolumn{5}{|c|}{$3.5 \mathrm{t}$}} & \multirow{2}{*}{\multicolumn{5}{|c|}{$7.5 t$}} & \multirow{2}{*}{\multicolumn{5}{|c|}{$\begin{array}{c}18 \mathbf{t} \\
\end{array}$}} & \multirow{2}{*}{\multicolumn{6}{|c|}{ 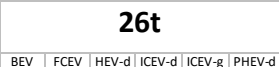 }} & \multicolumn{5}{|c|}{$32 t$} & \multicolumn{6}{|c|}{$40 t$} & \multicolumn{6}{|c|}{$60 t$} \\
\hline & & & & & & & & & & & & & & & & & & & HEV-d BE & & & & & HEV-d BE & $\mathrm{BEV} \mid \mathrm{FCE}$ & EV HEV & $\mid-d$ IIEVV & 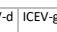 & B P PHEV- & V.d BEV & FCEV & HEV-d IC & ICEV-d ICE & EV-B P PHE & HEV-d & BEV $\mid$ FC & & AEV-dICE & EV-d IC & CEV-g Pt & \\
\hline & & & & $59 \quad 5$ & 56 & 56 & 56 & 59 & \begin{tabular}{l|l}
117 & 1.
\end{tabular} & $112 \quad 11$ & $12 \quad 112$ & $\begin{array}{ll}2 & 112\end{array}$ & $\begin{array}{ll}2 & 117\end{array}$ & 239 & 227 & 227 & 227 & 227 & 2392 & 2612 & 243243 & 243 & 243 & 261 & 296 & 269 & 69 & 69269 & $69 \quad 29$ & $96 \quad 296$ & $\begin{array}{ll}96 & 269\end{array}$ & 269 & 269 & 269 & 296 & 388 & 361 & 361 & 361 & 361 & 388 \\
\hline \multirow{7}{*}{ electricity consumption } & kilojoule & & 2030 & 56 & 54 & 54 & 54 & 56 & 1111 & 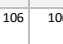 & $06 \quad 106$ & $6 \quad 106$ & $\begin{array}{ll}6 \quad 111 \\
6\end{array}$ & 229 & 217 & 217 & 217 & 217 & $229 \quad 2$ & 2502 & $232 \quad 232$ & 232 & ${ }^{232}$ & 250 & $\begin{array}{ll}284 & 2\end{array}$ & 257 & 57 & $\begin{array}{ll}57 & 257\end{array}$ & 57 & 284 & $\begin{array}{ll}34 & 257\end{array}$ & 257 & 257 & 257 & 284 & 371 & 344 & 344 & 344 & 344 & 371 \\
\hline & kilojoule & & 2040 & $52 \quad 5$ & 50 & 50 & 50 & 52 & $104{ }_{10}^{10}$ & $100 \quad 10$ & $00 \quad 100$ & $\begin{array}{l}0 \quad 100 \\
0\end{array}$ & $\begin{array}{l}0 \\
0\end{array}$ & 213 & 203 & 203 & 203 & 203 & $213 \quad 2$ & $230 \quad 2$ & $217 \quad 217$ & 217 & 217 & 230 & $\begin{array}{ll}260 & 2\end{array}$ & $239 \quad 2$ & $39 \quad 2$ & $39 \quad 239$ & 39 & 60 & $\begin{array}{ll}50 & 239\end{array}$ & 239 & 239 & 239 & 259 & 342 & 322 & 322 & 322 & 322 & 342 \\
\hline & kilojoule & & 2050 & 50 & 48 & 48 & 48 & 50 & 99 & 95 & $95 \quad 95$ & $\begin{array}{l}5 \quad 95 \\
\end{array}$ & 99 & 203 & 194 & 194 & 194 & 194 & $203 \quad 2$ & $220 \quad 20$ & $207 \quad 207$ & 207 & 207 & 220 & 249 & 228 & 28 & $28 \quad 228$ & 28 & $49 \quad 245$ & $\begin{array}{ll}99 & 228\end{array}$ & 228 & 228 & 228 & 249 & 327 & 307 & 307 & 307 & 307 & 327 \\
\hline & kilowatt hour per kilometer & & 2020 & 0.620 .0 & 0.00 & 0.00 & 0.00 & 0.62 & 0.930 .6 & $0.00 \quad 0.0$ & $00 \quad 0.00$ & 00.00 & $0 \quad 0.93$ & 1.28 & 0.00 & 0.00 & 0.00 & 0.001 & $1.28 \quad 1.2$ & $1.38 \quad 0.0$ & $.00 \quad 0.00$ & 0.00 & 0.00 & \begin{tabular}{l|l}
1.38 & 1
\end{tabular} & $\begin{array}{lll}1.70 & 0 .\end{array}$ & $1.00 \quad 0$. & $.00 \quad 0$. & $00 \quad 0.00$ & $00 \quad 1.7$ & 701.88 & 880.00 & 0.00 & $0.00 \quad 0$ & 0.00 & 1.88 & 2.29 & 0.00 & 0.00 & 0.00 & 0.00 & 2.29 \\
\hline & kilowatt hour per kilometer & & 2030 & 0.420 .0 & 0.00 & 0.00 & 0.00 & 0.42 & 0.650 .5 & $0.00 \quad 0.0$ & $00 \quad 0.00$ & 000.00 & $\begin{array}{ll}0 & 0.65 \\
0\end{array}$ & 1.01 & 0.00 & 0.00 & $0.00 \mathrm{O}$ & 0.00 & 1.011. & $1.10 \quad 0.0$ & $.00 \quad 0.00$ & 0.00 & 0.00 & \begin{tabular}{l|l}
1.10 & 1
\end{tabular} & $\begin{array}{lll}1.43 & 0 .\end{array}$ & $1.00 \quad 0.4$ & 000. & $00 \quad 0.00$ & $00 \quad 1.4$ & $43 \quad 1.51$ & $51 \quad 0.00$ & 0.00 & $0.00 \mathrm{o}$ & 0.00 & 1.51 & 1.870 & 0.00 & 0.00 & 0.00 & 0.00 & 1.87 \\
\hline & kilowatt hour per kilometer & & 2040 & 0.340 .00 & 0.00 & 0.00 & 0.00 & ${ }^{0.34}$ & 0.530 .0 & $0.00 \quad 0.0$ & $00 \quad 0.00$ & 000.00 & $\begin{array}{ll}0 & 0.53 \\
0\end{array}$ & 0.85 & 0.00 & $0.00 \mathrm{c}$ & 0.000 & $0.00 \quad 0$ & $0.85 \quad 0.5$ & 0.930 .0 & $.00 \quad 0.00$ & 0.00 & 0.00 & 0.931 & $1.23 \quad 0.0$ & .000. & 000. & $00 \quad 0.00$ & $00 \quad 1.2$ & 231.27 & 270.00 & 0.00 & 0.000 & 0.00 & 1.27 & \begin{tabular}{l|l}
1.59 & 0
\end{tabular} & 0.00 & 0.00 & 0.00 & 0.00 & 1.59 \\
\hline & kilowatt hour per kilometer & & 2050 & 0.270 .0 & 0.00 & 0.00 & 0.00 & 0.27 & 0.430 .6 & $0.00 \quad 0.0$ & $00 \quad 0.00$ & 00.00 & $\begin{array}{ll}0 & 0.43 \\
& \end{array}$ & 0.71 & 0.00 & 0.00 & 0.000 & 0.00 & 0.710 .7 & 0.790 .0 & $.00 \quad 0.00$ & 0.00 & 0.00 & $0.79 \quad 1$ & \begin{tabular}{l|l}
1.08 & 0.
\end{tabular} & $1.00 \quad 0.6$ & $.00 \quad 0$. & $00 \quad 0.00$ & $00 \quad 1.0$ & .081 .09 & 990.00 & 0.00 & $0.00 \quad 0$ & 0.00 & 1.09 & 1.390 & 0.00 & 0.00 & 0.00 & 0.00 & 1.39 \\
\hline \multirow[t]{5}{*}{ fuel consumption } & gram per kilometer & & 2020 & 0 & 67 & 76 & 74 & & 0 & $\begin{array}{ll}36 & 9\end{array}$ & $97 \quad 104$ & 34101 & 0 & 0 & 56 & 154 & 166 & 160 & 0 & 0 & $\begin{array}{ll}61 & 168\end{array}$ & 177 & 170 & & o & 73 & 03 & $13 \quad 205$ & 05 & & 82 & 228 & 242 & 234 & 0 & o & 103 & 285 & 303 & 293 & \\
\hline & gram per kilometer & & 2030 & & 57 & 55 & 52 & & 2 & 298 & $83 \quad 82$ & 32 & 0 & 0 & 47 & 134 & 132 & 117 & 0 & 0 & $\begin{array}{ll}51 & 148 \\
\end{array}$ & 143 & 128 & & 0 & 65 & 189 & $83 \quad 163$ & 63 & & 70 & 202 & 196 & 175 & 0 & 0 & 89 & 253 & 248 & 222 & \\
\hline & gram per kilometer & & 2040 & ${ }_{1}^{1}$ & 51 & 53 & 48 & & 2 & 237 & 75 & ${ }^{4}$ & & 0 & 37 & 123 & 121 & 109 & 0 & 0 & $\begin{array}{ll}41 & 136\end{array}$ & 132 & ${ }^{117}$ & & 0 & 54 & 180 & $74 \quad 148$ & 48 & & 55 & 185 & 180 & 160 & & 0 & 71 & 233 & 229 & 202 & \\
\hline & gram per kilometer & & 2050 & 1 & ${ }^{43}$ & 46 & 35 & & 0 & 196 & $64 \quad 66$ & $6 \quad 51$ & 0 & 0 & 31 & 107 & 111 & 84 & 0 & 0 & $\begin{array}{ll}35 & 120 \\
\end{array}$ & 121 & 91 & & 0 & 47 & 64 & $59 \quad 126$ & 26 & & 48 & \begin{tabular}{l|l}
364 \\
164
\end{tabular} & 166 & 125 & & 0 & 62 & 212 & 212 & 162 & \\
\hline & Mass in & licators & & & & & & & & & & & & & & & & & & & & & & & & & & & & & & & & & & & & & & & \\
\hline curb mass & kilogram & & 2020 & 6389200 & 2128 & 2229 & 2512 & ${ }^{6388}$ & 1020737 & 375391 & 104005 & 5 & 910206 & 164487 & 73977 & 77627 & \begin{tabular}{l|l}
927 & 84 \\
\end{tabular} & \begin{tabular}{l|l}
3880 & 16 \\
\end{tabular} & 6447182 & 264849 & 1918922 & 9021 & $9606{ }_{1}^{1}$ & 1826323. & 170 & 306 117. & 491189 & 9212666 & $66{ }^{2316}$ & 168228812 & 1213816 & 14297 & 1446915 & 541726 & 26811 & 3602820 & 007420 & 1093321 & 11292 & 2475 & 6026 \\
\hline & kilogram & & 2030 & 3582181 & 1903 & 1885 & 2069 & 3582 & 6154 337 & 3711346 & 643400 & 103630 & $0 \quad 6154$ & 10987 & 6568 & 83776 & 7527 & 10110 & 10987123 & 340753 & 337850 & 7724 & 81011 & 1233917 & 9131143 & 438117 & $31{ }^{1158}$ & 8712108 & $08{ }^{179}$ & 1218815 & 191943 & 12306 & 1226012 & 273518 & 18819 & 2592917 & 736618 & 180717 & 78531 & 18661 & 5928 \\
\hline & kilogram & & 2040 & 2592162 & 1736 & 1743 & 1995 & 2592 & 4604305 & 3922320 & 093181 & 13479 & $\begin{array}{ll}9 & 4604\end{array}$ & 8523 & 60896 & 36996 & 3196 & 6780 & 852396 & 6694701 & 107327 & 7235 & 7695 & 9694145 & 9988113 & 362116 & 30 115. & 131959 & 591998 & 988 14647 & 4710887 & 11224 & 1111311 & 178814 & 14647 & 20806 & 596416 & 16453 & 63321 & 17216 & 0806 \\
\hline & kilogram & & 2050 & 1998146 & 1598 & 1629 & 1811 & ${ }^{1998}$ & 366228 & \begin{tabular}{l|l}
8816 & 296
\end{tabular} & $\begin{array}{ll}612991 \\
261\end{array}$ & 113174 & $\begin{array}{ll}4 \quad 3662 \\
4\end{array}$ & 6977 & 55695 & 58795 & 9316 & \begin{tabular}{l|l}
6173 & 6 \\
\end{tabular} & $\begin{array}{ll}6976 \quad 80 \\
\end{array}$ & \begin{tabular}{l|l}
$8018 \quad 642$ \\
\end{tabular} & 1296763 & 36727 & 7027 & 8017134 & 34621128 & 283115 & $\begin{array}{ll}79 & 1147 \\
\end{array}$ & 701972 & $\begin{array}{ll}72 & 1346 \\
\end{array}$ & 46122085 & \begin{tabular}{l|l|l}
35 & 9839
\end{tabular} & 10201 & 1022910 & 0583 & 12085 & 17437 & 1449 & 14965 & 49501 & 15480 & 7436 \\
\hline available payload & kilogram & & 2020 & 142. & 1297 & 1196 & 913 & & & \begin{tabular}{l|l}
3650 & 351 \\
\end{tabular} & 153420 & 0 & ${ }^{6}$ & $1477^{16}$ & 1052810 & 0163 & 998 & 8445 & 1478 & 76611743 & 43417003 & 16904 & 16319 & 7662 & 8755 & 619201 & 76200 & 3319259 & & 7571311 & 1326109 & 256282 & 25456245 & & & & 885138 & 88992 & 87963 & 37450 & 3899 \\
\hline & kilogram & & 2030 & 1161 & 1522 & 1590 & 1356 & 1 & 1271405 & 2054396 & $\begin{array}{lll}361 & 4025 \\
\end{array}$ & 153795 & $\begin{array}{ll}5 & 1271 \\
\end{array}$ & 69381 & 113571 & 108811 & 1733100 & 08246 & 6938135 & 35851835 & 39218075 & 5182011 & $17824 \mathrm{H}$ & 13586140 & 1012204 & 1872013 & 942033 & 3819817 & & 01321106 & 0627982 & 276192 & 2776527 & 7190021 & 21106 & 3399642 & 248991 & 41918 & 20724 & 41264 & 3997 \\
\hline & kilogram & & 2040 & 833179 & 1689 & 1682 & 1430 & 833 & 2821433 & 1333421 & 164244 & 143996 & $\begin{array}{ll}6 \quad 2821 \\
\end{array}$ & 94021 & 1183611 & 155611 & 100611 & 11459 & 9402162 & 6231189 & 1518598 & 18690 18 & 182301 & 16231165 & 9372005 & 563202 & 952047 & 1219966 & 661693 & 93725278 & 7829038 & 3287012 & 2881228 & 813725 & 25278 & 391943 & 396143 & 4342 & 35934 & 42709 & 9119 \\
\hline & kilogram & & 2050 & 1427196 & 1827 & 1796 & 1614 & ${ }^{1427}$ & 3763460 & 1609446 & $164 \quad 4434$ & $34 \quad 4251$ & 13763 & 1094812 & 1235612 & 204611 & 199411 & 175210 & 10949179 & 79071945 & 19619162 & 21915318 & $1898{ }^{1}$ & 17908184 & 463206 & 642203. & 462045 & 55 19953 & 531846 & 46427840 & 4030086 & 529724 & 2969629 & 934227 & 27840 & 2428845 & 547644 & 49960 & & 44445 & 2489 \\
\hline payload & kilogram & based on loading factor & 2020 & 185 & 781 & 720 & 550 & & & $\begin{array}{ll}1489 & 143 \\
\end{array}$ & $134 \quad 1395$ & $95 \quad 1263$ & 1 & 626 & $44644^{4}$ & 43094 & 123940 & 4005 & $627 \quad 29$ & 2919664 & 5436478 & 3640 & 6217 & \begin{tabular}{l|l}
2919 & 3. \\
-
\end{tabular} & \begin{tabular}{l|l}
3152 & 74 \\
\end{tabular} & 42372 & 63721 & 126933 & 33315 & \begin{tabular}{l|l}
152 & 4694 \\
\end{tabular} & \begin{tabular}{l|l}
94 & 9347
\end{tabular} & 9175 & 91138 & 8774 & 4695 & & $2677^{13}$ & 139591 & 38891 & 13407 & 8556 \\
\hline & kilogram & & 2030 & & 917 & 957 & 816 & & 518165 & $1654 \quad 161$ & 161642 & $42 \quad 1548$ & $\begin{array}{ll}8 \quad 518 \\
\end{array}$ & 2942 & 48154 & 47014 & \begin{tabular}{l|l}
737 & 45 \\
\end{tabular} & 4589 & 294251 & $5176 \quad 700$ & 0076887 & 6935 & 6791 & \begin{tabular}{l|l}
5176 & 50
\end{tabular} & 5044 & 375 & $\begin{array}{ll}70 & 732 \\
\end{array}$ & 227734 & $\begin{array}{ll}34 & 504\end{array}$ & \begin{tabular}{l|l}
045 & 7556 \\
\end{tabular} & 5610017 & 9887 & 99409 & 9734 & 7556 & 12170 & 521115 & 15007 & 50621 & 14772 & 2171 \\
\hline & kilogram & & 2040 & 108. & 1017 & 7012 & 861 & 502 & 1151176 & \begin{tabular}{l|l}
1768 & 172
\end{tabular} & 201732 & $32 \quad 1610$ & $\begin{array}{l}0 \\
0\end{array} 1151$ & ${ }^{3987} 5$ & 50184 & 49004 & \begin{tabular}{l|l}
921 & 4 \\
9
\end{tabular} & 4725 & 398761 & 6184720 & 2077086 & 71216 & 6946 & \begin{tabular}{l|l}
6184 & 60 \\
\end{tabular} & \begin{tabular}{l|l}
6097 & 74 \\
\end{tabular} & 40373 & 0673. & 487188 & $88 \quad 609$ & 0979045 & 1910395 & 10275 & 1031510 & 0073 & 9050 & 1400415 & 573815 & 15563 & 56061 & 15290 & 4005 \\
\hline & kilogram & & 2050 & 859118 & 1100 & \begin{tabular}{|l|l}
0 & 1081 \\
\end{tabular} & 972 & 859 & 1535188 & 1880182 & 211805 & 091734 & $4 \quad 1535$ & 46425 & 52395 & 51075 & \begin{tabular}{l|l}
0.55 & 45 \\
\end{tabular} & 4983 & 464268 & 6823742 & 1287301 & 7297 & 7200 & 682366 & \begin{tabular}{l|l}
6547 & 74 \\
&
\end{tabular} & $431 \quad 73$ & & 64.7183 & & 6479967 & 67 10771 & 10641 & & 0055 & 9967 & & 528016 & 16096 & & 15911 & 5211 \\
\hline driving mass & kilogram & includes driver's mass & 2020 & 6464293 & 2984 & $4 \quad 3024$ & 3136 & ${ }^{6464}$ & 10282533 & 339541 & 195476 & 765667 & 7) 10282 & 1714911 & 193612 & 214612 & 241122 & 256017 & 17149212 & 12581520 & 20815475 & 1553615 & 15899 & 2125726 & 6397188 & 304190 & 87191 & 7919675 & 752639 & 39631582 & 3223238 & 235472 & 2365724 & $4266{ }^{31}$ & 31581 & 44658 & $44153^{34}$ & 34967 & & 39597 & 4657 \\
\hline & kilogram & & 2030 & 3658285 & 2894 & $4 \quad 2867$ & 2960 & 3658 & 6748510 & 100515 & 1555117 & 175253 & $\begin{array}{ll}36748 \\
\end{array}$ & 1400411 & 11458 & 161411 & 156411 & 176514 & 14004175 & 7591146 & 51514812 & 214733 & 14967 & 17591230 & 3032188 & 888190 & 76189 & 8419317 & 172303 & 03226450 & 5022036 & 22269 & 2217522 & 254426 & & 38175 & 272233 & 33089 & 29903 & 33509 & 8174 \\
\hline & kilogram & & 2040 & 3168278 & 2828 & 82831 & 2931 & 3168 & 5830493 & 1935500 & $04 \quad 4987$ & 875164 & $4 \quad 5830$ & 1258411 & 111831 & 134411 & 1315 & 158012 & 25844159 & 59531425 & 29214488 & $3^{14431} 1^{14}$ & 14716 & 1595321 & 1161188 & 840190 & 11189 & 37 19222 & 222116 & 16023772 & 7221358 & 321574 & 21503215 & 193623 & & 34886 & 177732 & 2091 & & 32581 & 4886 \\
\hline & kilogram & & 2050 & 2932271 & 2773 & 32785 & 2858 & 2932 & 5272477 & \begin{tabular}{l|l}
1772 & 485
\end{tabular} & $\begin{array}{ll}357 & 4875 \\
\end{array}$ & $\begin{array}{lll}75 & 4984\end{array}$ & $\begin{array}{l}4 \quad 5272 \\
4\end{array}$ & 1169410 & 108311 & 106211 & 109111 & 1231 & 11694149 & 49151393 & 3214139 & 1414514 & 14302 & 1491520 & 0183187 & 789189 & 78189 & 0919230 & 302018 & 18322127 & 2720685 & 20017 & & 116222 & 22127 & 32722 & 31 & 31136 & 11263 & 31466 & 2722 \\
\hline energy battery mass & kilogram & included in curb mass & 2020 & 4366 & & & & 3366 & 65 & 0 & & & 6566 & 9094 & & 0 & & & & 7883 & & & & 9782120 & 2012 & & & & 1201 & 01013328 & & & 0 & & & 16213 & & & & & 6211 \\
\hline & kilogram & & 2030 & 1971 & & & 0 & 1 & 3073 & 0 & & & 3073 & 4780 & & & & & $4780 \quad 51$ & 5189 & & & & 51886 & 6736 & & & & 673 & 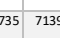 & & & & & 7138 & 8821 & & & & & 8820 \\
\hline
\end{tabular}




\begin{tabular}{|c|c|c|c|c|c|c|c|c|c|c|c|c|c|c|c|c|c|c|c|c|c|c|c|c|c|c|c|c|c|c|c|c|c|c|c|c|c|c|c|c|c|c|c|c|c|}
\hline & & & size & \multicolumn{6}{|c|}{$3.5 \mathrm{t}$} & \multicolumn{6}{|c|}{$7.5 t$} & \multicolumn{6}{|c|}{$18 t$} & \multicolumn{6}{|c|}{$26 t$} & \multicolumn{6}{|c|}{$32 t$} & \multicolumn{6}{|c|}{$40 t$} & \multicolumn{6}{|c|}{$60 t$} \\
\hline & & & owe & BEV & & & & $\mathrm{CV}-\mathrm{B}$ & HEV-d & BEV & & & & & & BEV & FCEV H & & & ICEV-B] & & BEV & & & & & & BEV & & & CEV-d IC & EV-B PH & & $\mathrm{BEV}$ & & & & EV-g PH: & & & & IEV-d IC & & & \\
\hline & kilogram & & 2040 & 1139 & & 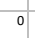 & & & 11 & ${ }_{1767}$ & 0 & 0 & (c) & & 1766 & 2818 & 0 & 0 & & & 2818 & 3080 & 0 & 0 & & & 3079 & 4092 & 0 & 0 & 0 & & 4091 & 4204 & 0 & 0 & 0 & & & 5278 & ${ }_{0}$ & 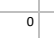 & 0 & & 5277 \\
\hline & kilogram & & 2050 & 666 & & 0 & & & & 1051 & 0 & 0 & & & 1051 & 1744 & 0 & 0 & & & 1743 & 1937 & 0 & 0 & & & 193 & 2654 & 0 & & & & 265. & 2675 & & & 0 & & & 3438 & 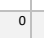 & & 0 & & \\
\hline \multirow[t]{5}{*}{ fuel mass } & kilogram & \multirow[t]{4}{*}{ included in curb mass } & 2020 & 0 & 17 & 54 & 61 & 59 & & 0 & 29 & 77 & 83 & 81 & 0 & 0 & 45 & 123 & 133 & 128 & 0 & 0 & 48 & 134 & ${ }^{141}$ & 136 & & 0 & 58 & 162 & 171 & 164 & 0 & 0 & 66 & 182 & 193 & 187 & & 0 & 82 & 228 & 243 & 234 & \\
\hline & kilogram & & 2030 & 0 & 14 & 46 & 44 & ${ }^{41}$ & & 0 & 24 & 66 & 65 & 58 & 0 & o & 38 & 107 & 105 & 94 & 0 & 0 & 41 & 118 & 115 & 102 & & 0 & 52 & ${ }^{151}$ & 146 & 131 & 0 & 0 & 56 & 161 & 157 & 140 & & 0 & 71 & 203 & 198 & 177 & \\
\hline & kilogram & & 2040 & 0 & ${ }_{11}$ & ${ }_{41}$ & 42 & 39 & & 0 & 18 & 60 & 59 & 54 & 0 & o & ${ }_{30}$ & 98 & 96 & 87 & 0 & 0 & ${ }^{33}$ & 109 & 106 & ${ }_{94}$ & & 0 & ${ }^{43}$ & ${ }^{144}$ & 139 & 118 & 0 & 0 & ${ }_{44}$ & ${ }_{148}$ & 144 & ${ }^{128}$ & ( & 0 & 5 & 187 & 183 & 162 & \\
\hline & kilogram & & 2050 & 0 & 9 & 34 & 37 & 28 & & 0 & 15 & 51 & 53 & 41 & 0 & 0 & 25 & 85 & 88 & 67 & 0 & 0 & 28 & 96 & 97 & 73 & 0 & 0 & 38 & 132 & ${ }^{127}$ & 101 & 0 & 0 & 38 & ${ }^{131}$ & 133 & 100 & & 0 & 50 & 170 & 169 & 129 & \\
\hline & \multicolumn{2}{|c|}{ Energy storage indicators } & & & & & & & & & & & & & & & & & & & & & & & & & & & & & & & & & & & & & & & & & & & \\
\hline \multirow[t]{4}{*}{ oxidation energy stored } & kilowatt hour & & 2020 & & 580 & 636 & 716 & 916 & & & 952 & 917 & 983 & 1242 & o & o & 1492 & 1456 & 1571 & 1974 & 0 & o & 1613 & 1588 & 1671 & 2096 & 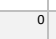 & s & 1944 & 1918 & 20172 & 2533 & 0 & 0 & 21862 & 21592 & 228828 & & & & 2740 & 2693 & 2871 & 3614 & \\
\hline & kilowatt hour & & 2030 & 0 & 472 & 534 & 519 & 638 & 0 & 0 & 784 & 776 & 764 & 902 & 0 & 0 & 1253 & 1253 & 1232 & 1446 & 0 & 0 & 1372 & 1383 & 1341 & 1576 & $0^{\circ}$ & ch & 1744 & 1767 & 1713 & 2014 & 0 & 0 & 18711 & 18881 & 183422 & 160 & & 2 & 2375 & 2371 & 2318 & 2733 & \\
\hline & kilowatt hour & & 2040 & 0 & 369 & 480 & 490 & 596 & 0 & 0 & 610 & 701 & 692 & ${ }^{834}$ & 0 & 0 & 987 & 1142 & 1123 & 1346 & 0 & 0 & 1085 & 1266 & 1230 & 1445 & 0 & c & 1431 & 1679 & 1624 & 1823 & 0 & 0 & 14791 & $\begin{array}{l}17231 \\
1\end{array}$ & 167619 & 1979 & 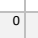 & 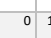 & 1886 & 2174 & 2130 & 2494 & \\
\hline & kilowatt hour & & 2050 & 0 & 291 & 395 & 421 & ${ }^{437}$ & 0 & & 494 & 588 & 612 & 625 & 0 & & 825 & 983 & 1018 & 1030 & 0 & $\circ$ & 922 & 1103 & 1114 & 1125 & & c & 1261 & 1514 & 1464 & 1555 & 0 & 0 & 12721 & $\begin{array}{ll}1508 & 1\end{array}$ & 152815 & 1544 & 0 & 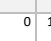 & 1662 & 1951 & 1999 & 1994 & \\
\hline \multirow[t]{5}{*}{ electric energy stored } & kilowatt hour & & 2020 & 524 & 0 & 0 & 0 & 0 & 524 & 788 & 0 & 0 & 0 & 0 & 788 & 1091 & 0 & 0 & 0 & 0 & 1091 & 1174 & 0 & 0 & 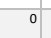 & 0 & ${ }^{1174}$ & 1441 & & 0 & 0 & & 1441 & 1599 & & & 0 & & 599 & 1996 & & 0 & 0 & 0 & 1945 \\
\hline & kilowatt hour & & 2030 & 355 & 0 & 0 & 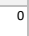 & 0 & 355 & 553 & 0 & 0 & 0 & 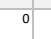 & 553 & 860 & 0 & 0 & 0 & ( & 860 & 934 & 0 & 0 & & 0 & 934 & 1212 & & 0 & 0 & & 1212 & 1285 & & 0 & 0 & & & 1588 & & & 0 & 0 & 1588 \\
\hline & kilowatt hour & & 2040 & 296 & 0 & 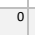 & & 0 & 296 & 459 & 0 & 0 & & & 459 & 733 & 0 & o & & & 733 & 801 & 0 & $\circ$ & & & 801 & 1064 & & & 0 & & 1064 & 1093 & & & 0 & & 093 & 1372 & & & 0 & 0 & 1372 \\
\hline & kilowatt hour & & 2050 & 233 & 0 & 0 & 0 & 0 & 233 & 368 & 0 & 0 & 0 & 0 & 368 & 610 & 0 & 0 & 0 & & 610 & 678 & 0 & o & & 0 & 678 & 929 & & 0 & 0 & & 929 & 936 & & 0 & 0 & & 936 & 1203 & & 0 & 0 & 0 & 120 \\
\hline & Componen & lacement indicators & & & & & & & & & & & & & & & & & & & & & & & & & & & & & & & & & & & & & & & & & & & \\
\hline batterylifetime replacements & unit & & 2020 & 0 & & 0 & 0 & 0 & & 1 & 1 & 1 & 0 & g & 1 & 0 & 0 & 0 & 0 & & 0 & 1 & 1 & 1 & & ${ }^{c}$ & & 2 & & $2^{2}+2>2$ & 0 & & & & & & 0 & & & & & & 0 & 0 & \\
\hline Dattery minetinne replacememis & ant & environmental burden of the & & & & & & & & & & & & & & & & & & & & & & & & & & & & & & & & & & & & & & & & & & & \\
\hline & unit & $\begin{array}{l}\text { last unit is entirely allocated } \\
\text { to the truck }\end{array}$ & 2030 & 0 & 0 & 0 & 0 & 0 & & & 1 & 1 & & & & 0 & 0 & 0 & & & 0 & & & & & & & & & & 0 & & & & & & 0 & & & & & & 0 & 0 & \\
\hline & unit & & 2040 & 0 & 0 & 0 & 0 & 0 & & 1 & 1 & 1 & 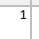 & & 1 & o & 0 & 0 & 0 & & ${ }^{0}$ & 0 & ${ }^{\circ}$ & o & & t & & 1 & & 1 & 1 & & & 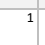 & & 1 & 1 & & & 1 & & 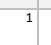 & 1 & 1 & \\
\hline & unit & & 2050 & 0 & 0 & 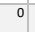 & & 0 & & & 0 & 0 & & & & 0 & 0 & & & & 0 & 0 & 0 & 0 & & & & & & & 1 & & & & & & 1 & & & & & & 1 & & \\
\hline fuel cell lifetime replacements & unit & rounded up, as the & 2020 & 0 & & & & 0 & & 0 & 1 & 0 & & & 0 & 0 & 1 & 0 & & & 0 & 0 & 1 & 0 & & & & 0 & & 0 & 0 & & & & & & 0 & & & & & & 0 & 0 & \\
\hline & & environmental burden of the & & & & & & & & & & & & & & & & & & & & & & & & & & & & & & & & & & & & & & & & & & & \\
\hline & unit & $\begin{array}{l}\text { last unit is entirely allocated } \\
\text { to the truck }\end{array}$ & 2030 & 0 & 0 & o & & 0 & & & 1 & 0 & & & 0 & 0 & & & & & & 0 & & 0 & & & & & & & 0 & & & & & & 0 & & & & & & 0 & 0 & \\
\hline & unit & & 2040 & 0 & 0 & 0 & 0 & 0 & & 0 & 1 & 0 & 0 & 0 & 0 & o & 0 & 0 & $\circ$ & & 0 & 0 & 1 & 0 & & 0 & & ${ }^{0}$ & & $\circ$ & 0 & & & 0 & & 0 & 0 & & & 0 & & 0 & 0 & 0 & \\
\hline & unit & & 2050 & 0 & ${ }^{0}$ & 0 & 0 & 0 & & & 1 & 0 & ( & & 0 & & & & & & 0 & & & & & & & & & & 0 & & & & & & 0 & & & & & & 0 & 0 & \\
\hline
\end{tabular}




\subsection{Comparison across powertrains and duty cycles}

Figures in this section shows the per vehicle-kilometer and per ton-kilometer GHG emissions for different powertrain types, driving cycles and years.

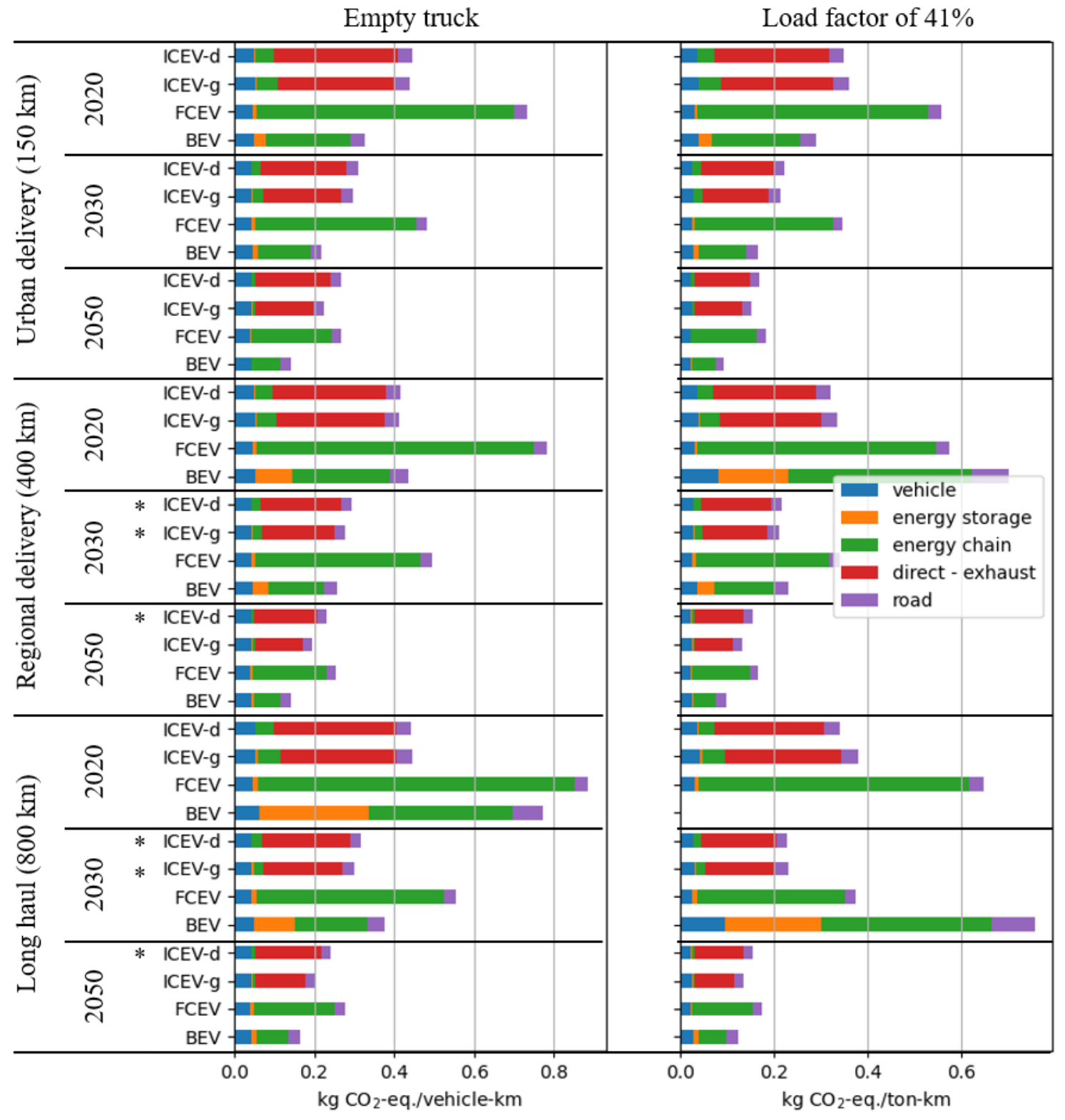

Figure 12 Per vehicle-km (left panel) and per ton-km (right panel) GHG emissions comparison across powertrains and years for 7.5-ton trucks, for different driving cycles. Fuel for ICEV-g: compressed natural gas. Fuel for FCEV: electrolysis-based hydrogen. * Vehicles marked with a star $(*)$ do not manage to comply with the $\mathrm{CO} 2$ emissions reduction targets (-15\% by $2025,-30 \%$ by 2030) despite energy efficiency improvements. Average European electricity is used for battery charging and hydrogen production. Vertical gray lines at the level of ICE vehicles represent their emissions without powertrain hybridization. 
Empty truck

Load factor of $36 \%$

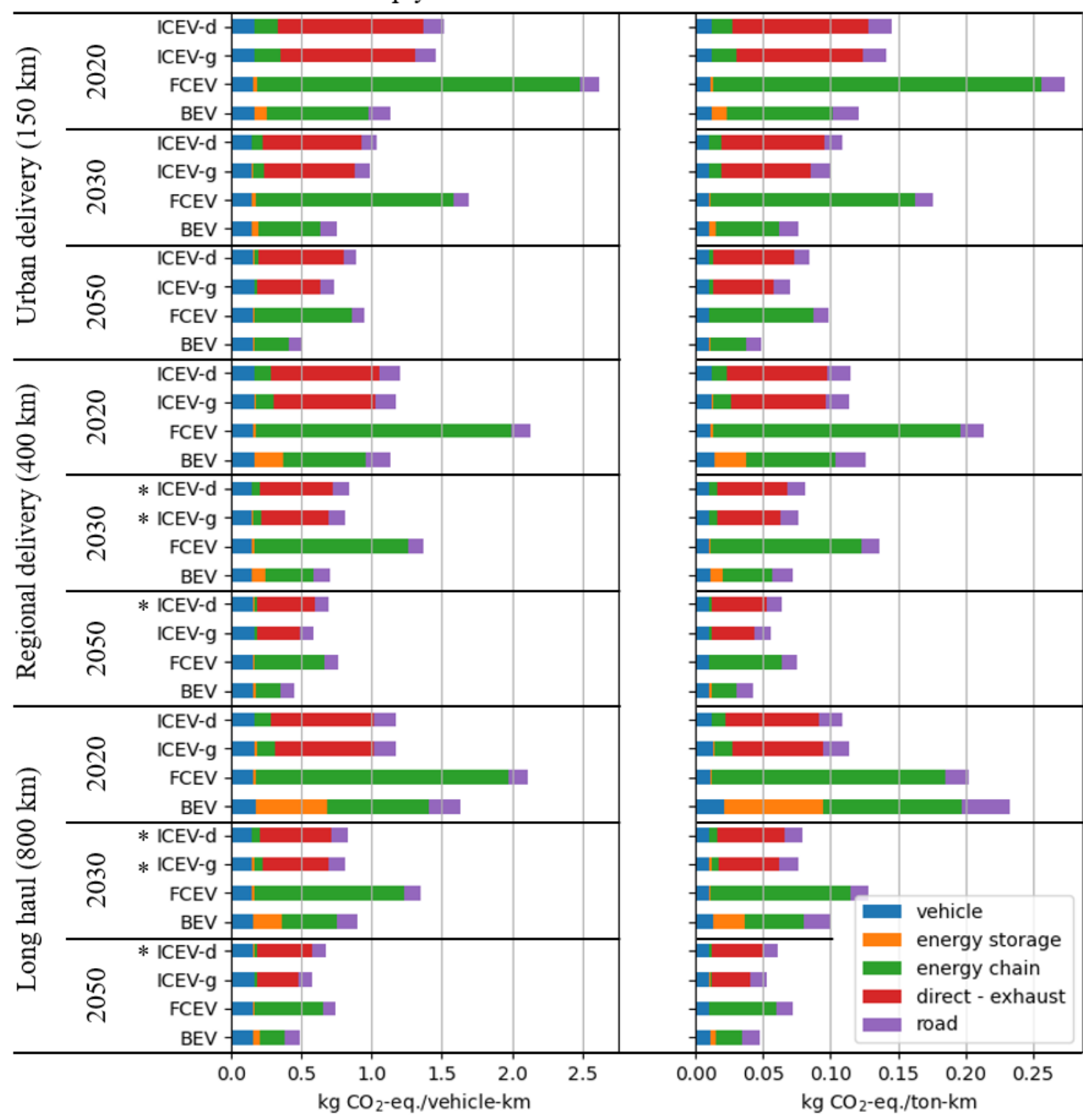

Figure 13 Per vehicle-km (left panel) and per ton-km (right panel) GHG emissions comparison across powertrains and years for 60-ton trucks, for different driving cycles. Fuel for ICEV-g: compressed natural gas. Fuel for FCEV: electrolysis-based hydrogen. * Vehicles marked with a star $(*)$ do not manage to comply with the $\mathrm{CO} 2$ emissions reduction targets ( $-15 \%$ by $2025,-30 \%$ by 2030$)$ despite energy efficiency improvements. Average European electricity is used for battery charging and hydrogen production. Vertical gray lines at the level of ICE vehicles represent their emissions without powertrain hybridization.

\subsection{Importance of size class}

The following figure illustrates the relation between per ton-kilometer GHG emissions and the gross vehicle weight of a diesel truck. 


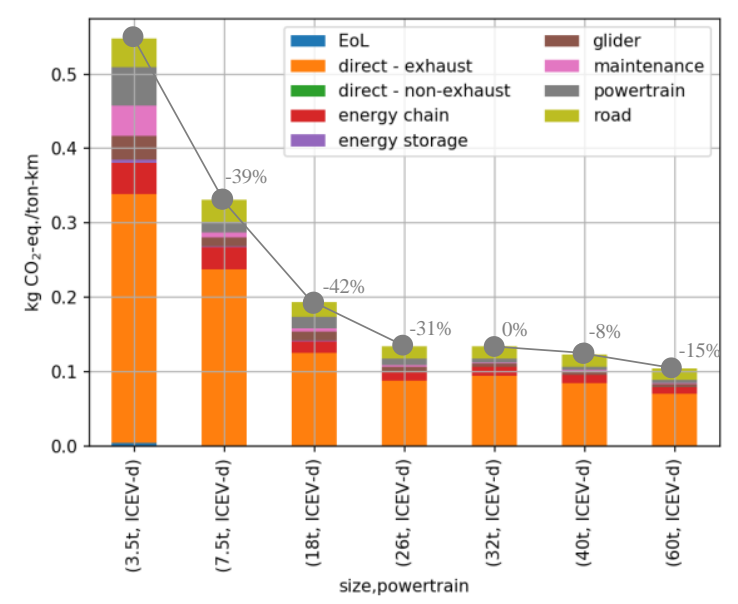

Figure 14 GHG emissions per ton-km function of gross vehicle weight, with relative difference with preceding size class, with a diesel powertrain in 2020

\subsection{Diesel, batteries, or fuel cells?}

The following figure illustrates the relation between the vehicle-kilometer GHG emissions of trucks of different powertrain types and the GHG intensity of the electricity supply in 2030 and 2050.

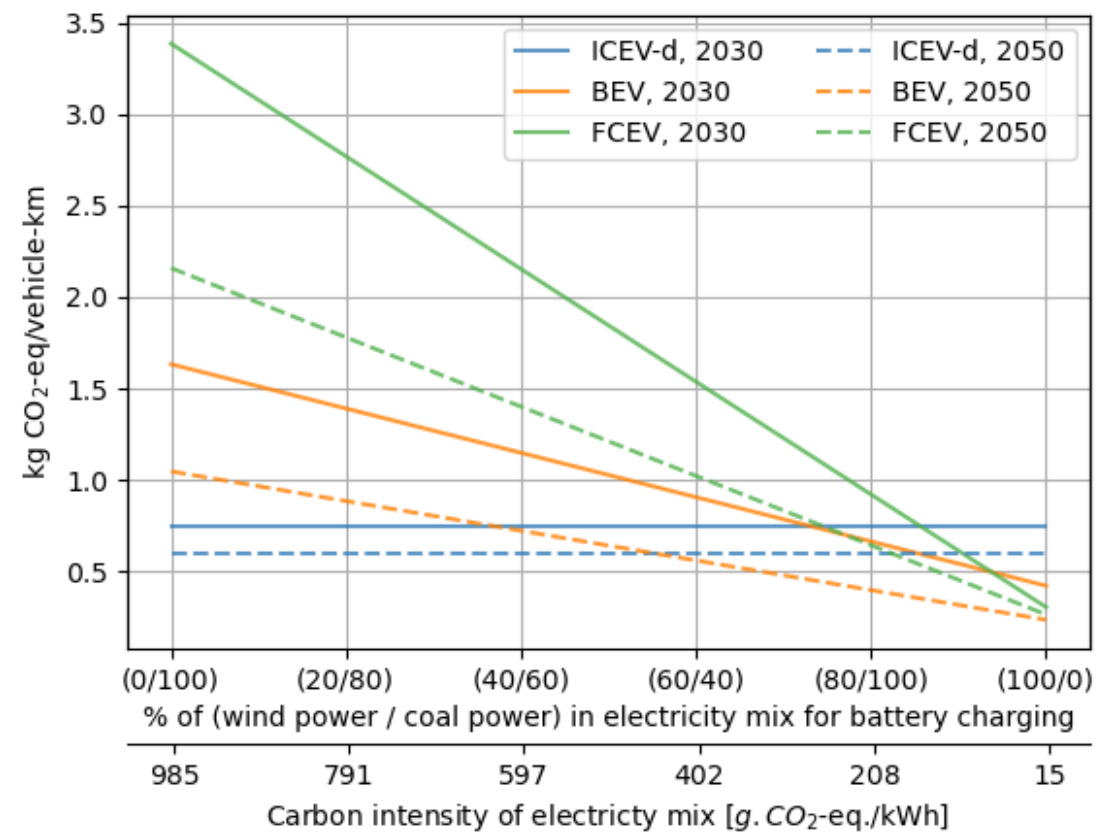

Figure 15 GHG emissions per vehicle-km as a function of the GHG intensity of electricity, with a range autonomy of $800 \mathrm{~km}$ : comparison between a 40-ton BEV, FCEV and ICEV-d truck driving without load 


\section{References}

(1) INFRAS. Handbook Emission Factors for Road Transport version 4.1 https://www.hbefa.net/e/index.html.

(2) European Commission. Vehicle Energy Consumption calculation TOol - VECTO https://ec.europa.eu/clima/policies/transport/vehicles/vecto_en (accessed Sep 15, 2020).

(3) Rodriguez, F. CO2 Standards for Heavy-Duty Vehicles in the European Union; 2019.

(4) Meszler, D.; Delgado, O.; Rodríguez, F.; Muncrief, R. EUROPEAN HEAVY-DUTY VEHICLES: COSTEFFECTIVENESS OF FUEL-EFFICIENCY TECHNOLOGIES FOR LONG-HAUL TRACTORTRAILERS IN THE 2025-2030 TIMEFRAME; 2018.

(5) Car2db. Car Make Model Trim Database MySQL, CSV Jan 01, 2020 — car2db.com https://car2db.com/ (accessed Jan 25, 2020).

(6) Sripad, S.; Viswanathan, V. Performance Metrics Required of Next-Generation Batteries to Make a Practical Electric Semi Truck. ACS Energy Letters. 2017, pp 1669-1673. https://doi.org/10.1021/acsenergylett.7b00432.

(7) Hill, N.; Norris, J.; Kirsch, F.; Dun, C. Light Weighting as a Means of Improving Heavy Duty Vehicles' Energy Efficiency and Overall CO2 Emissions Heavy Duty Vehicles Framework Contract-Service Request 2 Executive Summary Introduction and Scope; 2015.

(8) Wolff, S.; Seidenfus, M.; Gordon, K.; Álvarez, S.; Kalt, S.; Lienkamp, M. Scalable Life-Cycle Inventory for Heavy-Duty Vehicle Production. Sustain. 2020, 12 (13). https://doi.org/10.3390/su12135396.

(9) Wernet, G.; Bauer, C.; Steubing, B.; Reinhard, J.; Moreno-Ruiz, E.; Weidema, B. The Ecoinvent Database Version 3 (Part I): Overview and Methodology. Int. J. Life Cycle Assess. 2016, 21 (9), 12181230. https://doi.org/10.1007/s11367-016-1087-8.

(10) Cai, H.; Han, J.; Forman, G.; Divita, V.; Amgad, E.; Wang, M. Analysis of Petroleum Refining Energy Efficiency of U.S. Refineries. 2013, 16.

(11) Cozzolini, F. Life Cycle Assessment of Biofuels in EU/CH; 2018. 
(12) Foteinis, S.; Chatzisymeon, E.; Litinas, A.; Tsoutsos, T. Used-Cooking-Oil Biodiesel: Life Cycle Assessment and Comparison with First- and Third-Generation Biofuel. Renew. Energy 2020, 153, 588600. https://doi.org/10.1016/j.renene.2020.02.022.

(13) Davis, R. E.; Markham, J. N.; Kinchin, C. M.; Canter, C.; Han, J.; Li, Q.; Coleman, A.; Jones, S.; Wigmosta, M.; Zhu, Y. 2017 Algae Harmonization Study: Evaluating the Potential for Future Algal Biofuel Costs, Sustainability, and Resource Assessment from Harmonized Modeling; Golden, CO (United States), 2018. https://doi.org/10.2172/1468333.

(14) Van Der Giesen, C.; Kleijn, R.; Kramer, G. J. Energy and Climate Impacts of Producing Synthetic Hydrocarbon Fuels from CO2. Environ. Sci. Technol. 2014, 48 (12), 7111-7121. https://doi.org/10.1021/es500191g.

(15) Argonne GREET Publication : Life-Cycle Analysis of Shale gas and Natural Gas https://greet.es.anl.gov/publication-shale_gas (accessed Jan 17, 2021).

(16) Zhang, X.; Witte, J.; Schildhauer, T.; Bauer, C. Life Cycle Assessment of Power-to-Gas with Biogas as the Carbon Source. Sustain. Energy Fuels 2020, 4 (3), 1427-1436. https://doi.org/10.1039/c9se00986h.

(17) Zhang, X.; Bauer, C.; Mutel, C. L.; Volkart, K. Life Cycle Assessment of Power-to-Gas: Approaches, System Variations and Their Environmental Implications. Appl. Energy 2017, 190, 326-338. https://doi.org/10.1016/j.apenergy.2016.12.098.

(18) Lee, U.; Bhatt, A.; Hawkins, T. R.; Tao, L.; Benavides, P.; Wang, M. Life-Cycle Analysis of Renewable Natural Gas and Lactic Acid Production from Waste Feedstocks. 2020.

(19) Sternberg, A.; Bardow, A. Life Cycle Assessment of Power-to-Gas: Syngas vs Methane. ACS Sustain. Chem. Eng. 2016, 4 (8), 4156-4165. https://doi.org/10.1021/acssuschemeng.6b00644.

(20) Antonini, C.; Treyer, K.; Streb, A.; van der Spek, M.; Bauer, C.; Mazzotti, M. Hydrogen Production from Natural Gas and Biomethane with Carbon Capture and Storage - A Techno-Environmental Analysis. Sustain. Energy Fuels 2020, 4 (6), 2967-2986. https://doi.org/10.1039/d0se00222d.

(21) Antonini, C.; Treyer, K.; Moioli, E.; Bauer, C.; Marco, M. Hydrogen from Wood Gasification with CCS - a Techno-Environmental Analysis of Production and Use as Transport Fuel (in Review). Sustain. Energy Fuels 2020.

(22) Mehmeti, A.; Angelis-Dimakis, A.; Arampatzis, G.; McPhail, S.; Ulgiati, S. Life Cycle Assessment and 
Water Footprint of Hydrogen Production Methods: From Conventional to Emerging Technologies. Environments 2018, 5 (2), 24. https://doi.org/10.3390/environments5020024.

(23) Hajjaji, N.; Martinez, S.; Trably, E.; Steyer, J. P.; Helias, A. Life Cycle Assessment of Hydrogen Production from Biogas Reforming. Int. J. Hydrogen Energy 2016, 41 (14), 6064-6075. https://doi.org/10.1016/j.ijhydene.2016.03.006.

(24) Capros, P. EU Reference Scenario 2016. EU Ref. Scenar. 2016 2016, 27. https://doi.org/10.2833/9127.

(25) Xie, Y.; Posada, F.; Minjares, R. Diesel Sulfur Content Impacts on Euro VI Soot-Free Vehicles: Considerations for Emerging Markets. 2020. https://doi.org/10.1007/s11783-016-0859-5.

(26) Global progress toward soot-free diesel vehicles in 2019|International Council on Clean Transportation https://theicct.org/publications/global-progress-toward-soot-free-diesel-vehicles-2019 (accessed Jan 21, 2021).

(27) Evangelisti, S.; Tagliaferri, C.; Brett, D. J. L.; Lettieri, P. Life Cycle Assessment of a Polymer Electrolyte Membrane Fuel Cell System for Passenger Vehicles. J. Clean. Prod. 2017, 142, 4339-4355. https://doi.org/10.1016/j.jclepro.2016.11.159.

(28) Cox, B.; Bauer, C.; Mendoza Beltran, A.; van Vuuren, D. P.; Mutel, C. L. Life Cycle Environmental and Cost Comparison of Current and Future Passenger Cars under Different Energy Scenarios. Appl. Energy 2020, 269 (Cml). https://doi.org/10.1016/j.apenergy.2020.115021.

(29) Evangelisti, S.; Tagliaferri, C.; Brett, D. J. L.; Lettieri, P. Life Cycle Assessment of a Polymer Electrolyte Membrane Fuel Cell System for Passenger Vehicles. J. Clean. Prod. 2017, 142, 4339-4355. https://doi.org/10.1016/j.jclepro.2016.11.159.

(30) Dai, Q.; Kelly, J. C.; Gaines, L.; Wang, M. Life Cycle Analysis of Lithium-Ion Batteries for Automotive Applications. Batteries 2019, 5 (2), 48. https://doi.org/10.3390/batteries5020048.

(31) Pappis, I.; Howells, M.; Sridharan, V.; Gardumi, A.; Ramos, E. Energy Projections for African Countries; 2019. https://doi.org/10.2760/678700.

(32) International Energy Agency (IEA). World Energy Outlook 2017 https://www.iea.org/reports/worldenergy-outlook-2017 (accessed Jan 26, 2020).

(33) 1.A.3.b.i-iv Road transport 2019 — European Environment Agency 
https://www.eea.europa.eu/publications/emep-eea-guidebook-2019/part-b-sectoral-guidance-chapters/1energy/1-a-combustion/1-a-3-b-i/view (accessed Nov 2, 2020).

(34) Spielmann, M.; Bauer, C.; Dones, R.; Scherrer, P.; Tuchschmid, V. M. Swiss Centre for Life Cycle Inventories A Joint Initiative of the ETH Domain and Swiss Federal Offices Transport Services; 2007.

(35) Leading the Charge in eMobility https://adsal.dtnaapps.com/AssetLibrary/4317freightliner_ecascadia_sell_sh-2020-06-02.pdf (accessed Sep 29, 2020).

(36) RIGHT-SIZED INNOVATION https://adsal.dtnaapps.com/AssetLibrary/4318freightliner_em2_sell_sheet-2020-06-02.pdf (accessed Sep 29, 2020).

Volvo VNR Electric Semi First Drive Review: LIGHTS On The Road https://www.motor1.com/reviews/398699/volvo-vnr-electric-semi-first-drive-review-lights-on-the-road/ (accessed Sep 29, 2020).

(38) Workhorse https://workhorse.com/cseries.html (accessed Sep 29, 2020).

(39) Here's Everything We Know About the Tesla Semi-Truck https://www.trucks.com/2019/09/05/everything-we-know-about-the-tesla-semi-truck/ (accessed Sep 29, 2020).

(40) BYD ELECTRIC VEHICLES https://theicct.org/sites/default/files/BYD EV SEDEMA.pdf (accessed Sep 29, 2020).

(41) Mercedes-Benz Delivers First 10 eActros Electric Trucks https://insideevs.com/news/340380/mercedesbenz-delivers-first-10-eactros-electric-trucks/ (accessed Sep 29, 2020).

(42) The World's first fuel cell heavy goods vehicle able to fulfill Coop's logistics requirements https://h2energy.ch/wp-content/uploads/2017/06/Brochure-Truck.pdf (accessed Sep 29, 2020).

(43) World's First Fuel Cell Heavy-Duty Truck, Hyundai XCIENT Fuel Cell, Heads to Europe for Commercial Use - H2 Energy https://h2energy.ch/en/worlds-first-fuel-cell-heavy-duty-truck-hyundaixcient-fuel-cell-heads-to-europe-for-commercial-use/ (accessed Sep 29, 2020).

(44) SYMBIO: Renault Maxity H2 - h2-Share https://fuelcelltrucks.eu/project/symbio-renault-maxity-h2/ (accessed Sep 29, 2020).

(45) VDL: 27 ton hydrogen truck - h2-Share https://fuelcelltrucks.eu/project/vdl-27-ton-hydrogen-truck/ 
(accessed Sep 29, 2020).

(46) SCANIA: 4 hydrogen gas trucks with ASKO in Norway - h2-Share

https://fuelcelltrucks.eu/project/scania-four-hydrogen-gas-trucks-with-asko-in-norway/ (accessed Sep 29, 2020).

(47) Kenworth T680 Hydrogen Fuel Cell Heavy-Duty Truck | Hydrogen Cars Now https://www.hydrogencarsnow.com/index.php/kenworth-t680-fuel-cell-heavy-truck/ (accessed Sep 29, 2020).

(48) UPS: fuel cell electric Class 6 delivery truck - h2-Share https://fuelcelltrucks.eu/project/ups-fuel-cellelectric-class-6-delivery-truck/ (accessed Sep 29, 2020). 